UNIVERSIDADE DE SÃO PAULO

FACULDADE DE ECONOMIA, ADMINISTRAÇÃO E CONTABILIDADE DEPARTAMENTO DE ADMINISTRAÇÃO

PROGRAMA DE MESTRADO PROFISSIONAL EM EMPREENDEDORISMO

\title{
INOVAÇÃO COLABORATIVA EM PAÍSES EMERGENTES: PROCESSO DE GERAÇÃO DE IDEIAS
}

Miriam Martin

Orientadora: Prof. ${ }^{a}$ Dr. ${ }^{\text {a Jane A. Marques }}$

\section{SÃO PAULO}


Prof. Dr. Marco Antonio Zago

Reitor da Universidade de São Paulo

Prof. Dr. Adalberto Américo Fischmann

Diretor da Faculdade de Economia, Administração e Contabilidade

Prof. Dr. Roberto Sbragia

Chefe do Departamento de Administração

Prof. Dr. Martinho Isnard Ribeiro de Almeida

Coordenador do Programa de Mestrado Profissional em Empreendedorismo 


\title{
MIRIAM MARTIN
}

\section{INOVAÇÃO COLABORATIVA EM PAÍSES EMERGENTES: PROCESSO DE GERAÇÃO DE IDEIAS}

\author{
Dissertação apresentada ao Programa de \\ Mestrado Profissional em Empreendedorismo, \\ da Faculdade de Economia, Administração e \\ Contabilidade da Universidade de São Paulo \\ como requisito parcial para obtenção do título \\ de Mestre em Ciências.
}

Orientadora: Prof. ${ }^{a}$ Dr. ${ }^{a}$ Jane A. Marques

\section{Versão Corrigida}

(versão original disponível na Biblioteca da Faculdade de Economia, Administração e Contabilidade)

\section{SÃO PAULO}


FICHA CATALOGRÁFICA

Elaborada pela Seção de Processamento Técnico do SBD/FEA/USP

Martin, Miriam Inovação colaborativa em países emergentes: processo de geração de idéias / Miriam Martin. - São Paulo, 2016.

$114 \mathrm{p}$.

Dissertação (Mestrado) - Universidade de São Paulo, 2016.

Orientador: Jane A. Marques.

1. Inovação 2. Ideação 3. Brainstorming 4. Cooperação 5 . Estudo de caso I. Universidade de São Paulo. Faculdade de Economia, Administração e Contabilidade. II. Título.

CDD - 658.514 
À minha querida Yasmin. 



\section{AGRADECIMENTOS}

Fazer parte da primeira turma do Mestrado Profissional em Empreendedorismo da Faculdade de Economia, Administração e Contabilidade da Universidade de São Paulo foi uma honra porque me permitiu fazer parte da formação do curso de Mestrado Profissional em Empreendedorismo.

Testemunhei a dedicação de diversos membros docentes em disseminar essa nova modalidade de mestrado, o mestrado profissional, que abre a oportunidade para profissionais de áreas não acadêmicas de se aprimorar e crescer através de um ensino mais especializado, sempre embasado na teoria.

Agradeço a minha orientadora a Prof. ${ }^{\mathrm{a}}$ Dr $^{\mathrm{a}}$ Jane A. Marques por ter me selecionado como sua orientanda e pelo apoio durante todo o processo de desenvolvimento desta dissertação. A dedicação da Prof. ${ }^{a}$ Dr ${ }^{a}$ Jane foi imprescindível para que eu transformasse a minha curiosidade inicial, "Qual o melhor processo para gerar ideias para inovação?”, em um trabalho acadêmico.

Agradeço ao Prof. Dr. Martinho Isnard Ribeiro de Almeida, ao Prof. Dr. Marcelo Caldeira Pedroso e ao Prof. Dr. Fabio Lotti Oliva pelo suporte durante todo o curso e por acreditarem em meu potencial quando do processo de seleção.

Agradeço a todos os membros docentes com os quais tive a oportunidade de aprender durante a duração do curso de mestrado.

Agradeço aos meus colegas de turma, aos 20 pioneiros, que proporcionaram muitos momentos de aprendizado e também de diversão.

Agradeço ao apoio especial fornecido por Fabiana Caseiro, da secretaria do curso de Mestrado Profissional em Empreendedorismo.

Finalmente, agradeço a toda minha família, que sempre me apoiou em todas as minhas aventuras, principalmente à minha filha, que sempre tinha uma mensagem de incentivo para que eu acabasse a minha dissertação: "Do It. Just do it". 

"Se você quer transformar o mundo, experimente primeiro promover o seu aperfeiçoamento pessoal e realizar inovações no seu próprio interior." 



\section{RESUMO}

Este estudo se propõe a identificar os fatores que permitam melhorar a etapa de geração de ideias de um processo de inovação. A partir de um estudo de caso, de um dos processos de inovação executado pela empresa DuPont na América Latina, busca-se entender quais aspectos influenciam a etapa de geração de ideias no que se refere aos métodos utilizados e aos participantes envolvidos, de forma a identificar sugestões e melhorias para essa etapa do processo de inovação nesta empresa. No âmbito das ideias para a inovação, pesquisadores indicam que a preocupação das empresas é pela ideia excepcional, pois se sabe que, na fase de geração de ideias, o objetivo principal é gerar, capturar e selecionar a melhor ideia, aquela que pode se tornar mais lucrativa. A empresa estudada utilizou o processo de inovação denominado Emerging Markets Growth Initiatives (EMGI), implantado em 2003 e com a participação principalmente de funcionários na etapa de geração de ideias, durante doze anos, e que obteve sucesso em algumas inovações desenvolvidas com a aplicação desse processo. No entanto, com o passar do tempo houve diminuição de ideias inovadoras e, em 2015, esse processo foi substituído por um novo processo de inovação, conduzido pelos Centros de Inovação da organização. A partir do referencial teórico sobre inovação e geração de ideias e da pesquisa empírica de observação direta e de entrevistas em profundidade com uma amostra intencional, não representativa, de participantes desse processo, pode-se concluir que o método aplicado não afetou o desempenho do processo, mas que a repetição dos participantes pode ter sido um limitante após diversos anos de processo. A proteção da propriedade intelectual, que é um fator de vantagem competitiva, foi cuidadosamente observada na inclusão de colaboradores externos (clientes, consultores e acadêmicos). Colaboradores externos foram incluídos com moderação em cada etapa, não havendo consenso entre os respondentes, o que indica que a inclusão de participantes externos deve ser considerada caso a caso, haja vista também as políticas governamentais vigentes para a proteção de propriedade intelectual. Sugere-se engajar um volume maior de colaboradores externos, sendo necessário, entretanto, o aprofundamento nos estudos sobre as melhores práticas para proteger a propriedade intelectual.

Palavras-chave: Inovação, Ideação, Brainstorming, Cooperação, Estudo de caso. 


\begin{abstract}
The objective of this research is to identify the factors that may improve the idea generation phase of the innovation process. A case study of one of the innovation process executed by DuPont in Latin America was the basis to understand which aspects influence the idea generation phase, regarding methods applied and participants involved, with the purpose to identify suggestions and improvements to this step of the innovation process in this company. In the subject of ideas for innovation, researchers point out that companies' main concern is to find the exceptional idea, because is known that in the idea generation phase, the main objective is to generate, capture and select the best idea, the one that may become the most profitable. The company studied executed the Emerging Markets Growth Initiatives (EMGI) process, implemented in 2003, mainly with company's employees in the idea generation phase, during twelve years, and it was able to develop some successful innovation with this process. However, after some time, a reduction in innovative ideas was identified and, in 2015, this process was replaced by a new innovation process, led by the company Innovation Centers. From the theorical framework about innovation and idea generation in conjunction with an empiric research and in-depth interviews with an intentional sample, non-representative, of this process' participants, it was concluded that the method applied for idea generation did not interfere in the performance of the process, but the repetition of participants might have limited the process after several years of execution. The intellectual property protection, a factor of competitive advantage, was carefully evaluated when of the opening to external participantes (customers, consultants and academics). They were included with moderation in each step of the process, there was no consensus among the interviewees, indicating the inclusion of external participants should be considered case by case, evaluating also the current government policies regarding protection of intellectual property. It is suggested to include a higher volume of external colaborators, being needed, however, further studies about the best practices to protect the intellectual property.
\end{abstract}

Keywords: Innovation, Ideation, Brainstorming, Cooperation, Case Study. 


\section{Sumário}

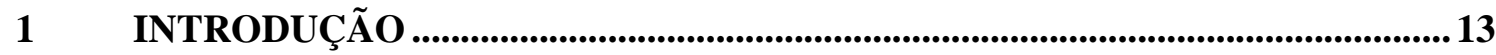

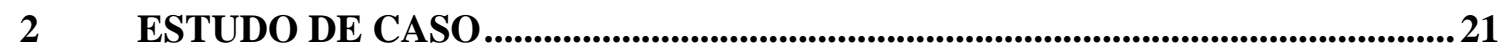

$2.1 \quad$ O PROCESSO EMGI ............................................................................................... 24

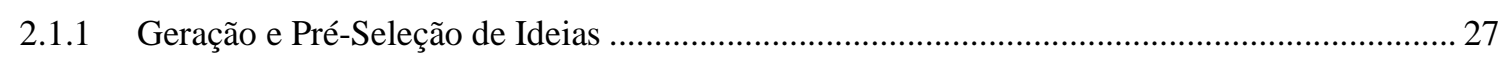

2.1.2 Plano de Negócio de Alto Nível................................................................................... 30

2.1.3 Plano de Desenvolvimento Estratégico ............................................................................. 31

2.2 PROBLEMÁTICA, QUESTÃO DE PESQUISA E OBJETIVOS ....................................... 32

$3 \quad$ REFERENCIAL TEÓRICO_.......................................................................................... 35

3.1 PROCESSOS DE INOVAÇÃO ……………………......................................................... 37

3.1.1 Pré-desenvolvimento ou FrontEnd of Innovation (FEI) ………………………………...... 38

3.2 GERAÇÃO DE IDEIAS .................................................................................................. 40

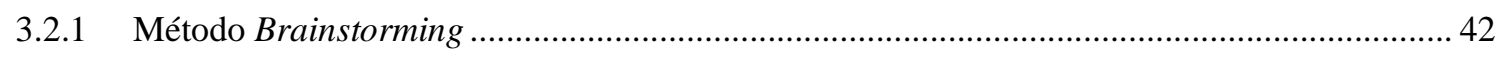

3.2.2 Participantes da fase de geração de ideias............................................................................... 44

4 PROCEDIMENTOS METODOLÓGICOS ................................................................49

5 ANÁLISE DOS DADOS COLETADOS..........................................................57

$5.1 \quad$ O PROCESSO EMGI ...................................................................................................... 59

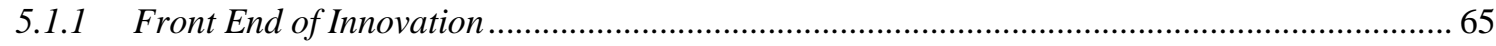

5.2 GERAÇÃO E PRÉ-SELEÇÃO DE IDEIAS ………….................................................... 70

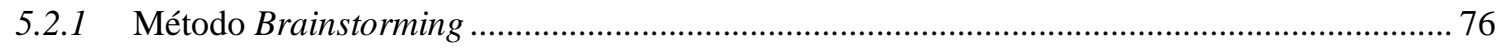

5.2.2 Participantes …………………………………………………………………. 83

5.3 PLANO DE NEGócio de ALTO NÍVEL E PLANO DE DESENVOLVIMENTO ESTRATÉGICO ............................................................................... 93

6 CONSIDERAÇÕES FINAIS, LIMITAÇÕES DA PESQUISA E PRINCIPAIS CONTRIBUIÇÕES....................................................................................97

REFERÊNCIAS .............................................................................................................103

APÊNDICE: INSTRUMENTO DE PESQUISA....................................................................... 111 



\section{INTRODUÇÃO}

O mundo está passando por uma quarta revolução industrial, baseada na transformação digital, que desafia o nosso entendimento por ser baseada na fusão de tecnologias que integram o físico, o digital e o biológico, conforme destaca Schwab (2015). Essa integração desestabiliza e cria novas oportunidades para as empresas, impondo aos seus líderes a pressão constante de entender as mudanças, avaliar o tamanho da oportunidade, desafiar paradigmas e inovar para acompanhar ou liderar essa transformação.

A inovação impulsiona as empresas a se transformarem, criando novos produtos, novos processos, novas formas de produção. Na teoria da criação destrutiva, Schumpeter (1961) apresenta a natureza evolutiva do ambiente em que as empresas capitalistas operam. Ambiente este que sofre influências de transformações políticas, sociais e econômicas, cujo fator principal para essa evolução é a inovação. Em se tratando de inovação, Schumpeter (1961) destaca como principal ameaça para as empresas a inovação que posiciona a empresa inovadora em uma posição de superioridade quanto à qualidade ou aos custos de seus produtos, o que afeta a base de seus competidores e não somente as suas práticas comerciais.

Há diversos exemplos de negócios líderes em seu segmento que estão sendo surpreendidos por inovações que podem gerar a ruptura do seu modelo de negócio e transformar o mercado, ameaçando o status quo de modelos antes dominantes. No Brasil pode-se citar como exemplo a desestabilização que os serviços da empresa Uber estão causando no modelo nacional de serviços de táxi $(\mathrm{G} 1,2016)$. Outro exemplo é o serviço de assinaturas da Netflix que permite o acesso a filmes e séries on demand e vem desafiando a tradicional TV aberta e a TV paga (SÁ, 2015). Como esses dois exemplos vão afetar os tradicionais serviços existentes no Brasil ainda está para ser revelado, mas eles indicam que inovar tem que ser um processo constante para negócios que queiram continuar ou avançar no seu mercado de atuação. 
De acordo com o Manual de Oslo (OECD, 2005), que padroniza a medição da inovação: "An innovation is the implementation of a new or significantly improved product (good or service), or process, a new marketing method, or a new organisational method in business practices, workplace organization or external relations." ${ }^{1}$ Ainda, segundo o referido manual, a inovação pode ocorrer nos setores públicos e privados da economia, sendo as suas orientações focadas na medição da inovação no setor privado (OECD, 2005).

Pesquisa publicada pela OECD (2015b), conforme apresentado na figura 1, com o objetivo de levantar os investimentos em Pesquisa e Desenvolvimento (P\&D) realizados pelas empresas privadas, universidades, governos e outras entidades sem fins lucrativos, identificou que o setor que mais investe é o privado. Para os países membros do OECD (legenda OECD) e da União Europeia (legenda EU28), os percentuais de investimento empresarial em P\&D nos últimos 10 anos têm se mantido constantes na faixa de $60 \%$. O destaque fica para a China que teve aumento de investimento pelo setor empresarial nos últimos dez anos.

\footnotetext{
1 Tradução livre da autora: "Uma inovação é a implementação de um novo produto, um produto melhorado significativamente (materiais ou serviços) ou um processo, um novo método de marketing, ou um novo método organizacional nas práticas de negócios, na organização do ambiente de trabalho ou nas relações externas."
} 
Figura 1 - Investimentos de diferentes países² em P\&D, por setores (dados de 2013)

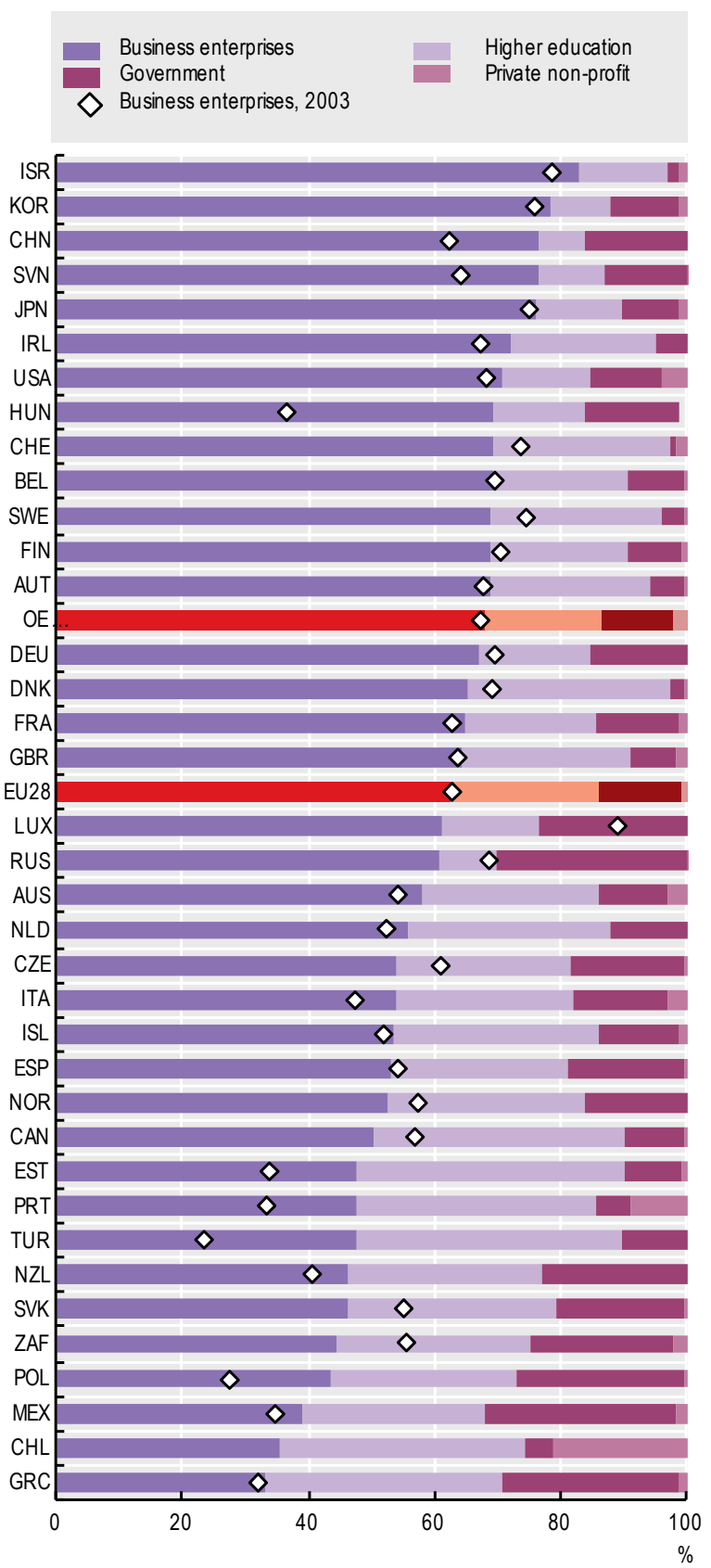

Fonte: OECD (2015b).

\footnotetext{
${ }^{2}$ Legenda dos países, na ordem em que aparecem na figura: ISR = Israel, KOR = Coreia do Sul, CHN = China, SVN = Eslovênia, JPN = Japão, IRL = Irlanda, USA = Estados Unidos, HUN = Hungria, CHE = Suíça, BEL = Bélgica, SWE = Suécia, FIN = Finlândia, AUT = Áustria, OE = Organização Europeia, DEU = Alemanha, DNK = Dinamarca, FRA = França, GBR = Reino Unido, EU28 = União Europeia, LUX = Luxemburgo, RUS = Rússia, AUS = Austrália, NLD = Holanda, CZE = República Tcheca, ITA = Itália, ISL = Islândia, ESP = Espanha, NOR $=$ Noruega, $\mathrm{CAN}=$ Canadá, EST $=$ Estônia, $\mathrm{PRT}=$ Portugal, TUR $=$ Turquia, $\mathrm{NZL}=$ Nova Zelândia, $\mathrm{SVK}=$ Eslováquia, $\mathrm{ZAF}=$ África do Sul, $\mathrm{POL}=$ Polônia, $\mathrm{MEX}=$ México, $\mathrm{CHL}=$ Chile, $\mathrm{GRC}=$ Grécia.
} 
Inovação é uma das forças motrizes para a economia dos países desenvolvidos e emergentes. As empresas privadas são as grandes investidoras na inovação e podem ter os seus investimentos em inovação distribuídos em ativos físicos e em ativos baseados no conhecimento (OECD, 2015a).

Inovação está inserida também na lista de prioridades estratégicas das empresas, como pode ser observado na Figura 2. A pesquisa publicada pelo Boston Consulting Group (BCG, 2015), com o objetivo de identificar as empresas mais inovadoras, demonstra que nos últimos dez anos a inovação é uma constante prioridade, sendo que $79 \%$ das empresas respondentes identificaram a inovação como uma de suas prioridades.

Figura 2 - Posição da inovação entre as prioridades estratégicas

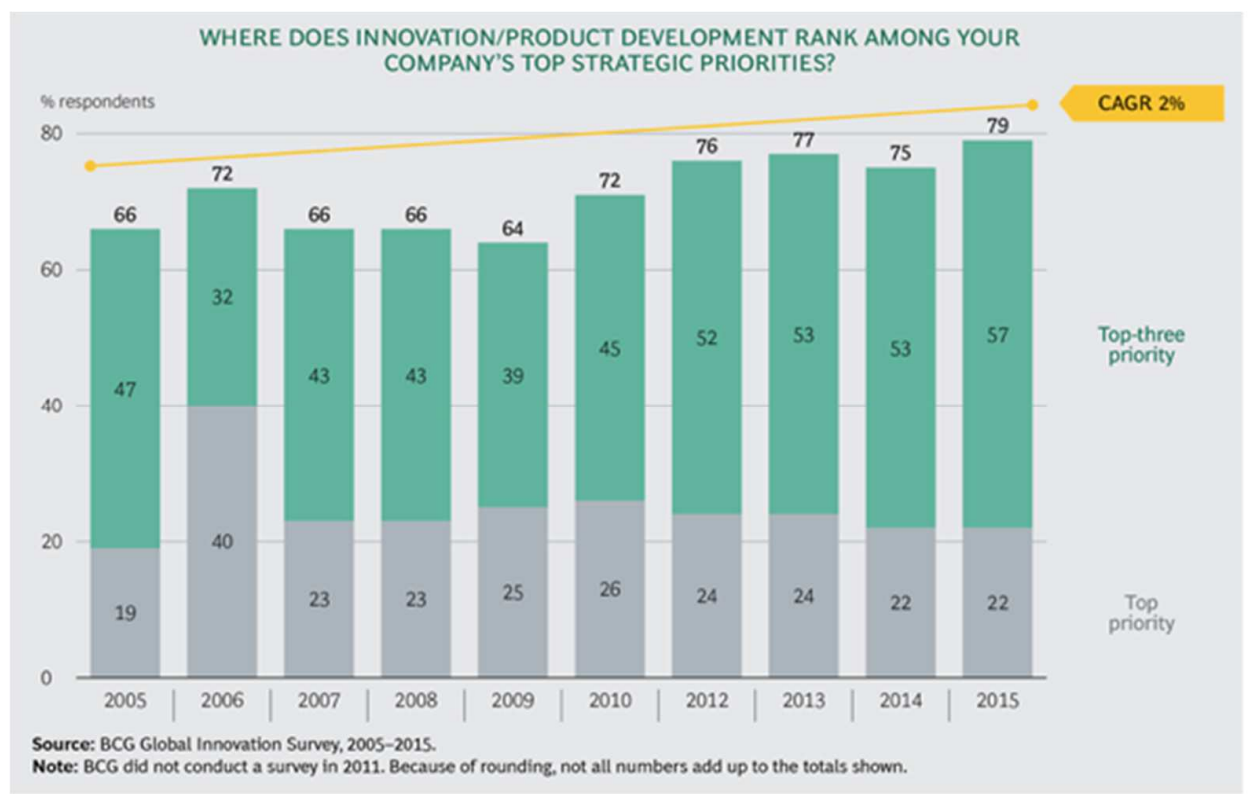

Fonte: BCG (2015).

Inovar é o resultado de um processo, intencionalmente estabelecido, com o intuito de buscar oportunidades que possam ser desenvolvidas e se tornar uma inovação. Raramente inovações ocorrem ao acaso. As inovações de sucesso surgem de empresas que estabelecem processos de inovação disciplinados (DRUCKER, 2002).

Diversos autores estudaram o processo de inovação, dentre os quais se destaca Cooper (2001, 2008) pelo desenvolvimento de um processo disciplinado denominado Stage-Gate ${ }^{\circledR}$ (vide Figura 3). Nesse processo, as empresas seguem uma sequência de estágios e pontos de decisão 
como forma de garantir que as atividades importantes para cada estágio sejam desenvolvidas e que, após cada estágio, os patrocinadores do projeto possam decidir se ainda há um caso de negócio para seguir em frente ou não. O Stage-Gate ${ }^{\circledR}$ abrange todo o processo de inovação desde o descobrimento da oportunidade, chamado de discovery, até a revisão após o lançamento do produto no mercado, chamado de post-launch review.

Figura 3 - Fluxo do Stage-Gate ${ }^{\circledR}$

\section{Stage-Gate ${ }^{\circledR}$ : A five stage, five-gate system along with Discovery and Post-Launch Review}

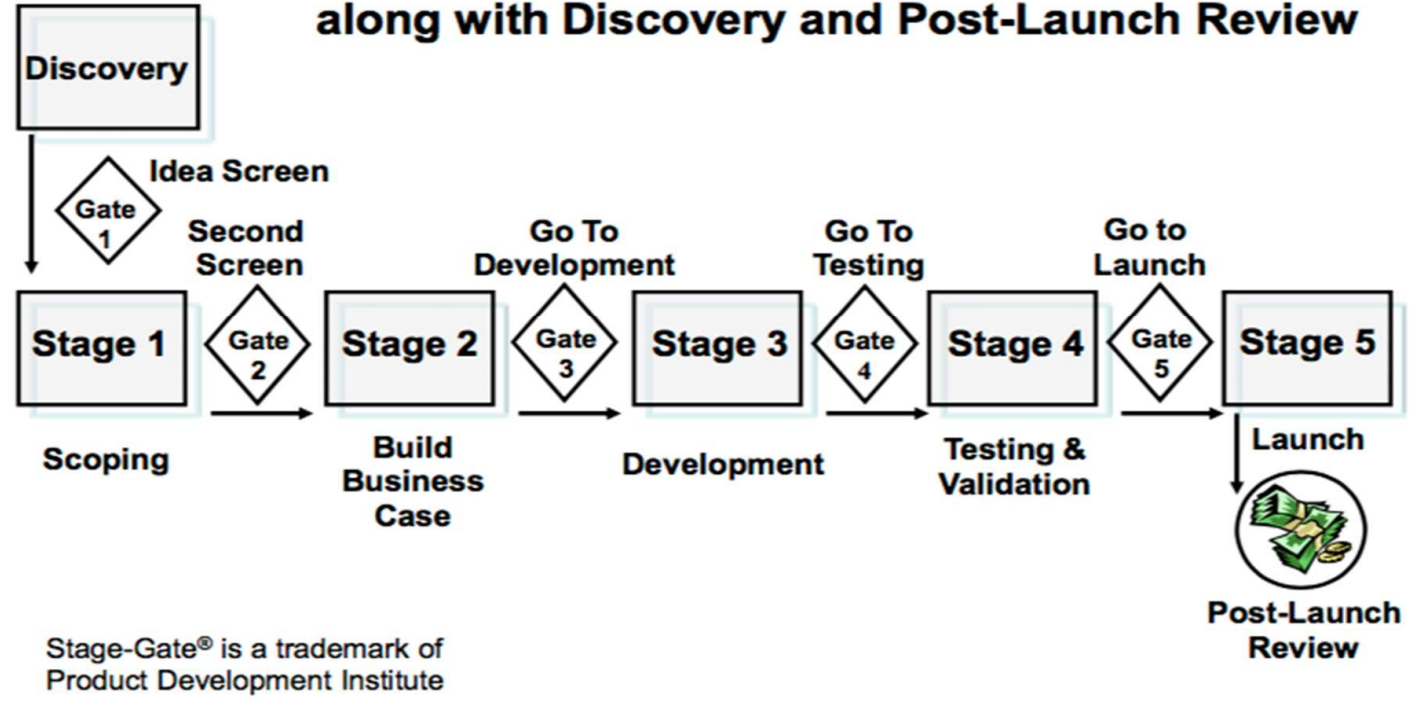

Fonte: Cooper (2001).

Praticamente qualquer iniciativa de inovar parte de uma ideia a ser desenvolvida, seja esta um novo produto, um serviço, uma mudança organizacional ou uma iniciativa de marketing. Dessa forma, a ideia tem uma participação crítica no processo de inovação (GIROTRA; TERWIESCH; ULRICH, 2010).

No âmbito das ideias para a inovação, pesquisadores apresentam que a busca das empresas é pela ideia excepcional, aquela que trará maiores retornos financeiros à organização. Dessa forma, no processo de inovação, o volume de ideias não é o objetivo principal, mas a habilidade de gerar, capturar, selecionar e desenvolver a ideia excepcional, aquela que será mais lucrativa.

Na etapa de geração de ideias (Figura 4), o objetivo final é o processo ter auxiliado na seleção da melhor ideia (TERWIESCH; ULRICH, 2009; GIROTRA; TERWIESCH; ULRICH, 2010). 
Figura 4 - Quatro fatores que afetam o desempenho do processo de geração de ideias

Generation process

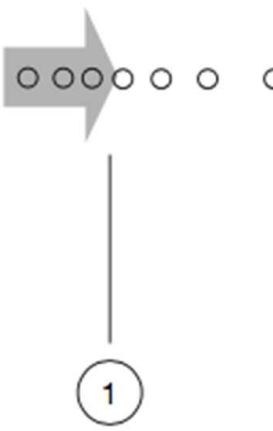

The number of ideas generated
Best idea

generated

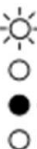

0 000 0000

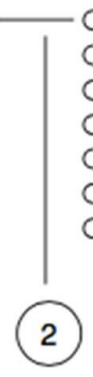

The average quality of the ideas generated
Selection process

Best idea

selected

Fonte: Girotra, Terwiesch, Ulrich (2010).

A fonte de ideias vem da junção do conhecimento com a criatividade (AMABILE, 1988). As empresas empregam diferentes fontes de conhecimento para alavancar projetos de inovação. Estudos comparativos, realizados por Pinho e Fernandes (2015), Figura 5, sobre as fontes de informação usadas por empresas para novos projetos de inovação tecnológica, em diferentes países em desenvolvimento, demonstram que há variações conforme o país. Seus estudos identificam treze formas diferentes de obter informações, sendo que as fontes predominantes são o conhecimento interno da própria empresa e os clientes.

Quanto à criatividade, Brem, Puente-Diaz e Agogué (2016) apresentam três dimensões que a influenciam em ambientes organizacionais: os fatores do ambiente organizacional, as competências de liderança relevantes para gerenciar essa criatividade e, finalmente, as ferramentas, técnicas e métodos para estimular o pensamento criativo em grupos. 
Figura 5 - Fontes de informação usadas por empresas quando da sugestão de novos projetos de inovação tecnológica

\begin{tabular}{|c|c|c|c|c|c|c|c|c|c|c|c|c|}
\hline \multirow[t]{2}{*}{ Sources } & \multicolumn{2}{|c|}{ India } & \multicolumn{2}{|c|}{ China } & \multicolumn{2}{|c|}{ Malaysia } & \multicolumn{2}{|c|}{ Mexico } & \multicolumn{2}{|c|}{ Brazil } & \multicolumn{2}{|c|}{ USA } \\
\hline & $\%$ & $\mathrm{R}$ & $\%$ & $\mathrm{R}$ & $\%$ & $\mathbf{R}$ & $\%$ & $\mathbf{R}$ & $\%$ & $\mathbf{R}$ & $\%$ & $\mathrm{R}$ \\
\hline $\begin{array}{l}\text { Firms' own } \\
\text { manufacturing } \\
\text { process }\end{array}$ & 81.0 & 1 & 67.6 & 6 & 86.7 & 1 & 48.8 & 4 & 71.6 & 1 & 73.7 & 2 \\
\hline Customers & 71.7 & 2 & 89.4 & 1 & 70.9 & 3 & 64.3 & 1 & 68.2 & 2 & 90.4 & 1 \\
\hline $\begin{array}{l}\text { Public research } \\
\text { institutes }\end{array}$ & 17.0 & 12 & 51.3 & 13 & 37.1 & 12 & 27.4 & 9 & 46.6 & 8 & na & na \\
\hline $\begin{array}{l}\text { Independent } \\
\text { suppliers }\end{array}$ & 41.4 & 6 & 53.3 & 12 & 46.3 & 9 & 40.1 & 6 & 40.1 & 10 & 45.6 & 4 \\
\hline $\begin{array}{l}\text { Technical } \\
\text { publications } \\
\text { and reports }\end{array}$ & 50.8 & 4 & 56.0 & 9 & 61.8 & 5 & 43.7 & 5 & 49.7 & 6 & na & na \\
\hline Affiliated suppliers & 38.1 & 7 & 62.3 & 7 & 80.3 & 2 & 25.3 & 11 & 50.3 & 5 & na & na \\
\hline Universities & 14.4 & 13 & 56.0 & 9 & 34.1 & 13 & 27.9 & 8 & 57.4 & 3 & 31.6 & 6 \\
\hline Competitors & 33.3 & 8 & 70.5 & 4 & 54.0 & 7 & 34.1 & 7 & 36.7 & 11 & 40.5 & 5 \\
\hline Internet & 55.1 & 3 & 70.9 & 3 & 62.0 & 4 & 57.1 & 2 & 47.8 & 7 & na & na \\
\hline $\begin{array}{l}\text { Consulting or } \\
\text { contract R\&D } \\
\text { firms }\end{array}$ & 24.0 & 11 & 54.3 & 11 & 57.1 & 6 & 19.6 & 12 & 24.1 & 12 & 22.8 & 7 \\
\hline $\begin{array}{l}\text { Fairs and } \\
\text { expositions }\end{array}$ & 28.5 & 10 & 59.3 & 8 & 42.4 & 10 & 52.5 & 3 & 53.1 & 4 & na & na \\
\hline $\begin{array}{l}\text { Indigenous } \\
\text { knowledge } \\
\text { systems }\end{array}$ & 50.8 & 4 & 81.8 & 2 & 41.3 & 11 & na & na & 40.7 & 9 & na & na \\
\hline $\begin{array}{l}\text { Cooperative or } \\
\text { joint venture } \\
\text { with other firms }\end{array}$ & 28.8 & 9 & 68.2 & 5 & 53.5 & 8 & 27.4 & 9 & 24.1 & 12 & 49.6 & 3 \\
\hline
\end{tabular}

Note: $\mathrm{R}=$ rank; na = data not available; numbers in italics are not fully comparable to data from other countries.

Fonte: Pinho, Fernandes (2015).

Este estudo busca explorar a etapa de geração de ideias, com o intuito de aumentar o entendimento dessa etapa do processo de inovação. Sendo a ideia o ponto de partida para todo o processo de inovação, a curiosidade da pesquisadora era: como habilitar um processo de inovação em que a fase de geração de ideias potencialize o nascimento da próxima inovação? A etapa de geração de ideias é composta por duas fases: a primeira, a geração de ideias em si; a segunda, a seleção dessas ideias. Este estudo foca na primeira etapa, a geração de ideias. Pesquisa realizada para identificar as empresas mais inovadoras (BCG, 2015) (vide Figura 6) aponta a falta de grandes ideias como o quinto maior obstáculo que as empresas enfrentam para obtenção do retorno do investimento em inovação. 
Figura 6 - Maiores obstáculos para gerar retorno sobre investimentos nos investimentos com inovação

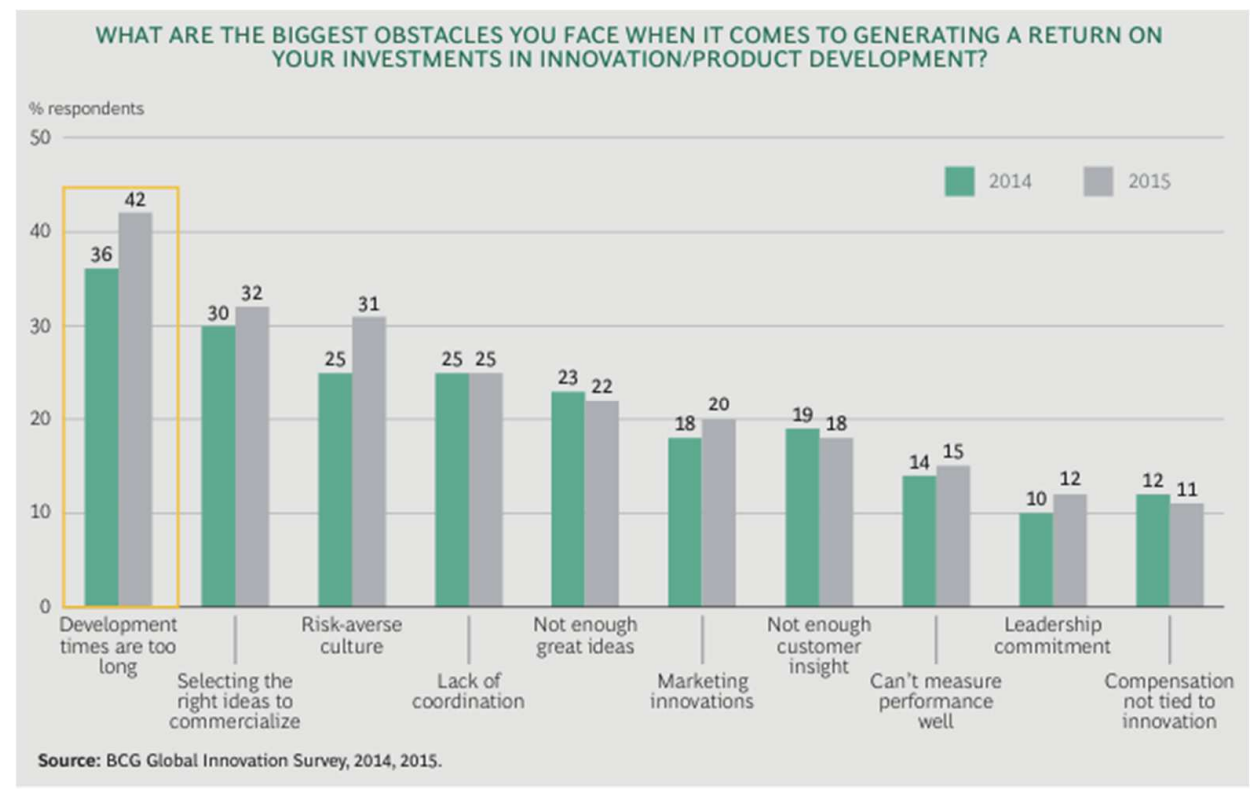

Fonte: BCG (2015).

Para entender os fatores que afetam a etapa de geração de ideias foi realizado um estudo de caso na empresa DuPont na América Latina, uma multinacional americana que figura como uma das 50 empresas mais inovadoras do mundo, de acordo com o ranking do Boston Consulting Group (2015). O estudo de caso focou no processo específico de inovação chamado Emerging Markets Growth Initiatives (EMGI), que tem por objetivo alavancar inovação na América Latina, incentivando a colaboração entre diferentes unidades de negócio. Esta dissertação se propõe a identificar os fatores que permitam melhorar a etapa de geração de ideias em um processo de inovação, com foco no método utilizado para gerar ideias e na composição dos participantes envolvidos durante a aplicação do método.

Este estudo se inicia apresentando o caso estudado. Na sequência, expõe o referencial teórico no qual esta pesquisa se embasou. Posteriormente discute a metodologia utilizada, em seguida apresenta a análise dos dados coletados, as considerações finais, limitações da pesquisa e principais contribuições. 


\section{ESTUDO DE CASO}

A empresa DuPont é uma multinacional norte-americana de ciências em operação desde 1802 (DUPONT, 2016d). A empresa está presente em mais de 90 países e tem como propósito trabalhar de forma colaborativa para desenvolver soluções, produtos e serviços que minimizem grandes problemas de âmbito mundial (DUPONT, 2016e).

Durante os seus mais de 213 anos de existência, a empresa DuPont se posiciona como líder em inovação, integrando química, engenharia, ciências de materiais e ciências biológicas. A empresa DuPont possui o domínio de tecnologia e competências científicas (Figura 7) que permiterm a inovação através de descobrimentos científicos, pesquisa e desenvolvimento de produtos e melhoria de processos para atender as necessidades nas áreas de alimentação, energia e proteção (DUPONT, 2016f)

Figura 7 - A Ciência da DuPont

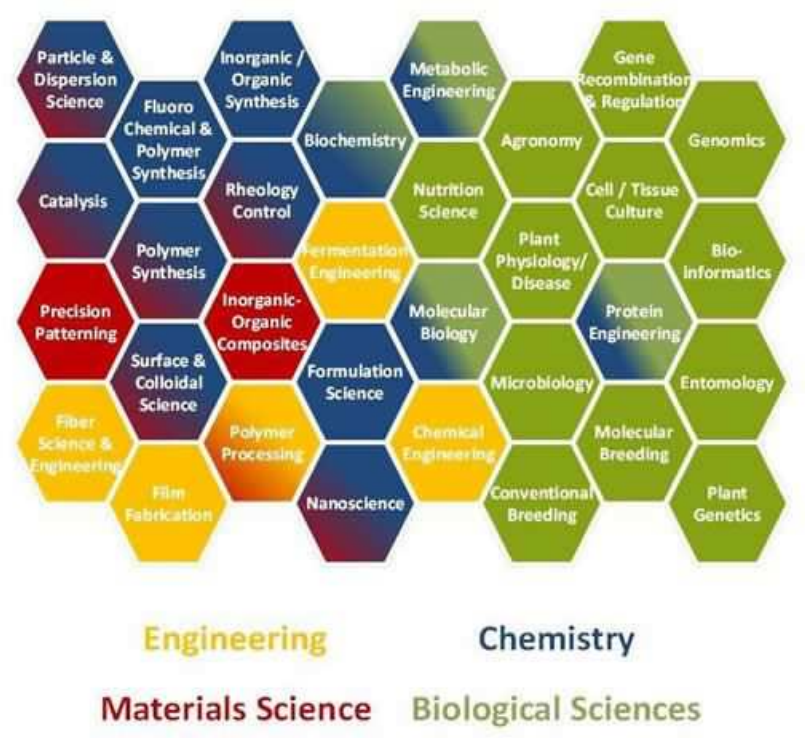

Fonte: DUPONT (2016f).

A inovação ocorre com uma equipe de desenvolvimento espalhada ao redor do mundo, com mais de 9.000 engenheiros e cientistas, distribuídos em mais de 150 centros de Pesquisa e Desenvolvimento (P\&D) (DUPONT, 2016c). A empresa DuPont possui oito grandes centros de $\mathrm{P} \& \mathrm{D}$, que conduzem pesquisas em múltiplas disciplinas. Esses oito centros estão localizados 
nos Estados Unidos (três), Brasil (um), Índia (um), China (um), Dinamarca (um) e Suíça (um). (DUPONT, 2015a).

Além dos centros de $\mathrm{P} \& \mathrm{D}$, a empresa DuPont possui uma rede de doze Centros de Inovação distribuída ao redor do mundo, que tem por objetivo fomentar a colaboração entre a empresa, seus clientes e parceiros estratégicos para gerar soluções para resolver necessidades do mercado (DUPONT, 2016b). Em 2015, esses Centros de Inovação desenvolveram mais de 500 projetos (DUPONT, 2016a).

Em 2015, a empresa DuPont investiu mundialmente US\$1,9 bilhões em P\&D e teve um faturamento superior a US\$ 25 bilhões. O faturamento advindo da venda de novos produtos correspondeu a $31 \%$ do faturamento total, com mais 1.600 novos produtos comercializados. $\mathrm{O}$ investimento em P\&D representou 8\% do faturamento total (DUPONT, 2016a).

A empresa DuPont tem passado por grandes transformações durante os seus anos de existência e um dos principais fatores que as alavancaram é a inovação. A empresa é reconhecida como líder em inovação nos Estados Unidos, bem como no Brasil, sendo escolhida como uma das empresas mais inovadoras em diversos rankings. Por exemplo, em 2015, a empresa DuPont foi selecionada pelo quinto ano consecutivo para constar na lista Top 100 Global Innovators realizada pela Thomson-Reuters (DUPONT, 2016a) e foi eleita uma das 50 empresas mais inovadoras por pesquisa realizada pelo Boston Consulting Group (BCG, 2015). No Brasil, a empresa DuPont foi a segunda colocada na pesquisa Best Innovator realizada pela A.T.Kearney com o apoio da revista Época Negócios (FELIX; GALEMBEK; CUNHA, 2015).

Em se tratando de processos de inovação, a empresa DuPont possui processos estruturados, com o objetivo de manter uma constante fonte de inovação: "We manage each project through a disciplined stage-gate process and critically evaluate them from both a technical and marketback perspective, and make appropriate adjustments to achieve or exceed our commercialization targets" ${ }^{3}$ (DUPONT, 2016a).

\footnotetext{
${ }^{3}$ Tradução livre da autora: "Nós gerenciamos cada projeto através de um processo disciplinado de stage-gate e avaliamos criticamente esses projetos por ambas as perspectivas, técnica e de mercado, e fazemos os devidos ajustes para atingir ou exceder os objetivos de comercialização".
} 
Os Centros de Inovação juntamente com os centros de pesquisa locais e as unidades de negócios colaboram com clientes, universidades, governos, entidades não governamentais e parceiros estratégico para gerar soluções inovadoras para os mercados locais e global (DUPONT, 2016a). Normalmente esses processos focam no desenvolvimento de soluções por uma única unidade de negócio.

Na América Latina, a empresa DuPont predomina no Brasil e no México, países que apresentam desafios específicos devido ao potencial de crescimento e por estarem em uma fase emergente. A empresa também está presente na Argentina, Chile, Colombia, Peru e Venezuela. Porter e Kramer (2011) destacam que mercados emergentes apresentam desafios não encontrados em economias desenvolvidas, como problemas de infraestrutura, restrição de acesso a recursos naturais, problemas de segurança física e patrimonial, etc. Para atender a essas necessidades surge a importância da inovação em produtos e em processos, através da criação de soluções específicas ou do redesenho de soluções existentes.

A necessidade de focar em prioridades do mercado específico da América Latina, agregada aos interesses de obter investimentos para essas prioridades, levou a liderança desta região a criar um novo processo de inovação, chamado de Emerging Markets Growth Initiatives (EMGI). O desenho do processo EMGI possui como grandes diferenciais: a) um processo de geração de ideias utilizando a imersão dos participantes em um processo criativo; b) os projetos selecionados têm como requisito obrigatório a colaboração por meio de produtos, tecnologias ou conhecimento de mais de uma unidade de negócio; c) o produto tem de ser desenvolvido e lançado no mercado no prazo de doze meses; d) o investimento é corporativo e limitado, sendo o valor de orçamento disponível para cada ciclo divido igualitariamente entre os projetos aprovados. O processo EMGI também apresenta um outro fator diferenciador, a utilização do conceito de triple bottom line como princípio para selecionar as ideias.

O termo triple bottom line surgiu em meados dos anos noventa e carrega o conceito que o sucesso de uma empresa não deve ser medido somente pelo desempenho financeiro, mas também pelo seu desempenho social e ético, e pelo desempenho em relação à atenção dedicada ao meio ambiente (NORMAN; MACDONALD, 2003). 
Assim, o processo EMGI utiliza tal conceito no processo de seleção de ideias, buscando expandir o entendimento dos colaboradores para categorizar as ideias apresentadas não somente pelo seu potencial financeiro, mas também pelas contribuições sociais e para o meio ambiente.

O processo EMGI é um dos processos de inovação utilizados na empresa DuPont e por isso foi selecionado para este estudo. A experiência da pesquisadora como observadora direta de etapas do EMGI e membro do grupo que gerenciava a execução do processo gerou o conhecimento do processo que está descrito a seguir. Além disso foram consultados documentos internos que não estão formalmente publicados.

\subsection{O PROCESSO EMGI}

O processo EMGI tem por objetivo lançar produtos, bens e serviços que agreguem valor aos mercados dos países da América Latina por meio da colaboração de diferentes unidades de negócios e buscando a identificação de oportunidades que poderiam não chegar a ter visibilidade nos processos tradicionais: primeiro, porque não há um incentivo explícito para a colaboração entre unidades de negócios; segundo, porque o potencial de retorno financeiro é inevitavelmente menor se comparado com o potencial encontrado no mercados da China e Índia. Vale ressaltar que, apesar de focar em iniciativas para a região da América Latina, todas as oportunidades selecionadas pelo processo têm de estar alinhadas com a estratégia global da empresa e com a estratégia dos negócios participantes.

O processo EMGI foi desenvolvido por líderes da organização da América Latina e implantado em 2003. Os seus princípios básicos são a) foco: indústrias de atuação da empresa; b) participantes: liderança da América Latina, líderes de negócios, engenheiros, técnicos e especialistas nas indústrias selecionadas e líderes em potencial; c) processo: utilização de processos já estabelecidos e de conhecimento dos times participantes; d) patrocinadores: presidentes, vice-presidentes e diretores das unidades de negócios.

Tal processo era executado periodicamente, normalmente com intervalo de dois anos e, ao longo dos seus doze anos de existência, foi passando por melhorias com o intuito de se tornar mais eficiente. $\mathrm{O}$ seu fluxo macro é apresentado na Figura 8 e é composto por três grandes 
etapas, que podem ser traduzidas como geração e pré-seleção de ideias, plano de negócio de alto nível e plano de desenvolvimento estratégico.

Na primeira etapa ocorre a geração, o desenvolvimento e a seleção das ideias. Ao final da primeira etapa, ocorre um gate e os patrocinadores escolhem as ideias que moverão para a próxima fase. Além da seleção dos projetos, os patrocinadores definem a equipe multidisciplinar e o líder para cada projeto que será desenvolvido durante a segunda etapa.

Na segunda etapa, se desenvolve uma análise da viabilidade do projeto e valida se as suposições desenvolvidas durante a primeira fase. Ao final da segunda etapa, ocorre outro gate que determina os projetos com viabilidade econômica e que atendam aos princípios estabelecidos para os projetos que serão executados sob o processo EMGI. Esses projetos seguirão para a terceira e última etapa.

Na última etapa ocorre o desenvolvimento do modelo de negócios, do business case em formato de pitch para apresentação aos patrocinadores. Um novo gate é realizado para aprovação final dos projetos, com o objetivo de obter investimento para o seu desenvolvimento. Normalmente nessa etapa é confirmada a unidade de negócio primária, que será a responsável por conduzir o projeto de desenvolvimento, lançá-lo no mercado e manter o produto no seu portfólio como fornecedora do produto final.

Cada ciclo do processo EMGI, composto pelas três etapas descritas, dura até seis meses. O objetivo é que ao final de cada ciclo, de duas a três ideias desenvolvidas em projetos de negócios sejam aprovadas pelos patrocinadores e obtenham investimentos para a execução da etapa de desenvolvimento e comercialização.

Há um prazo de doze meses após os investimentos serem liberados para completar o desenvolvimento e lançar o produto nos mercados definidos no business case. Durante esse prazo, os projetos são administrados como uma venture, ou seja, o investimento é corporativo e o patrocínio continua corporativo, como forma de manter o momento do projeto e impedir que o seu andamento seja afetado pela operação ou por outros projetos específicos das unidades de negócios envolvidas em cada projeto de desenvolvimento. 
Figura 8 - Processo EMGI

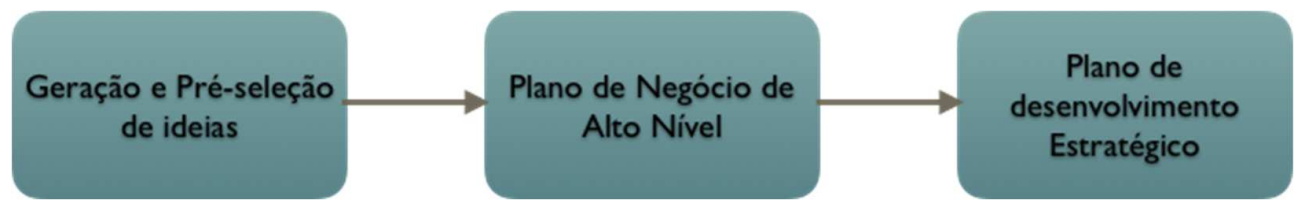

Fonte: Elaborado pela autora.

Desde a sua implantação, em 2003, onze inovações foram geradas, e desta destacam-se como exemplos de sucesso os produtos Solecina ${ }^{\mathrm{TM}} \mathrm{e}^{\text {DuPont }}{ }^{\mathrm{TM}}$ Armura $^{\circledR}$ (WANICK, 2011).

Solecina $^{\mathrm{TM}}$ foi desenvolvido pela DuPont América Latina com o objetivo de prover nutrição a baixo custo para a população de classe D do México, como parte da estratégia de crescimento da área de agricultura e nutrição. Solecina ${ }^{\mathrm{TM}}$ é um mix de proteína de soja e carne, com propriedades de consistência similar a da carne, com menos gordura e colesterol (FLETCHER, 2006), de valor mais acessível que a carne.

DuPont $^{\mathrm{TM}}$ Armura $^{\circledR}$ (Figura 9) é um sistema de blindagem automotiva de preço acessível, desenvolvido para o mercado de São Paulo e lançado em 2008, alinhado com a estratégia de crescimento na área de segurança. É um nível de blindagem destinado à proteção em eventos comuns em grandes centros urbanos contra armas de calibre 38 e que diminui o desgaste na estrutura do carro, devido ao menor peso (SPOTORNO, 2011).

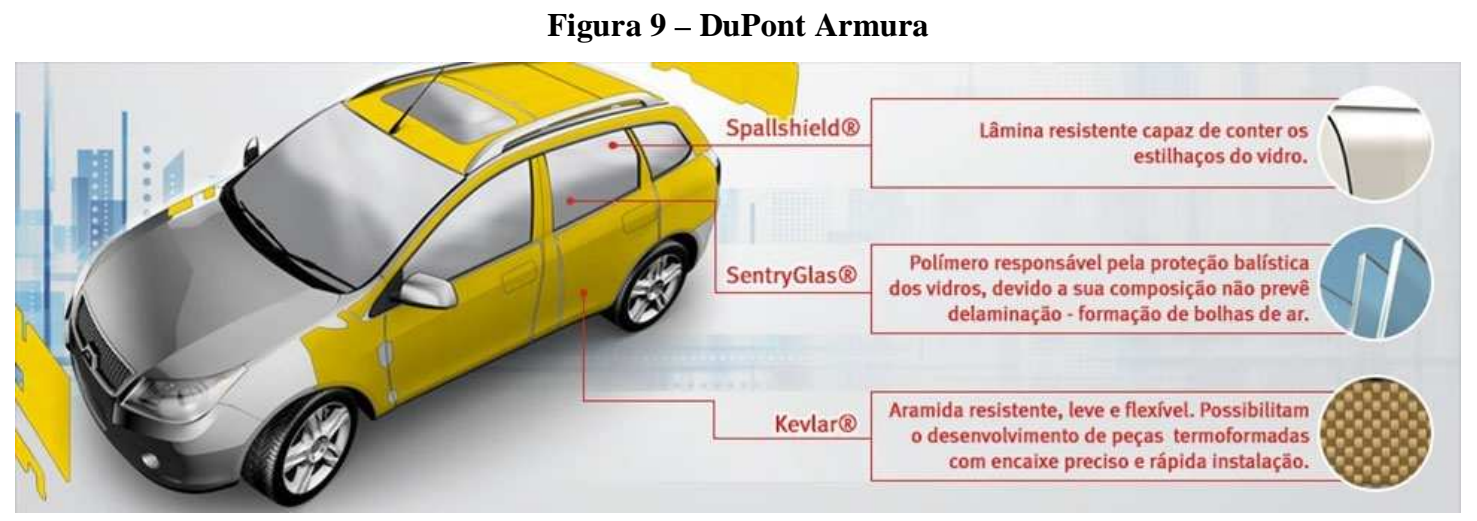

Fonte: DuPont (2008)

O DuPont ${ }^{\mathrm{TM}}$ Armura ${ }^{\circledR}$ foi idealizado durante um processo de geração de ideias sobre o tema segurança no ano de 2007. Durante o processo de geração de ideias usando a metodologia 
Futures Wheel chegou-se à ideia de desenvolver um sistema de blindagem acessível com a junção de duas unidades de negócios, Advanced Fibers e Packaging and Industrial Polymers.

A ideia do sistema de blindagem acessível veio da experiência da DuPont em prover os materiais para clientes de blindagem de níveis mais altos que o NBR 15000 - Nivel I e do conhecimento da DuPont da cadeia de valor para produtos de blindagem.

O projeto seguiu as etapas do processo EMGI até a sua aprovação para desenvolvimento. Com o investimento aprovado foi estabelecido o prazo de 12 meses para desenvolvimento e comercialização do produto. Além da criação de uma nova solução, o sistema de blindagem acessível Nível I, outra inovação foi introduzida na DuPont América Latina: a comercialização de produtos para consumidores diretos, que exigiu a criação de um novo modelo de negócio e a nova unidade de negócio na DuPont América Latina. Na sequência detalha-se as etapas do processo EMGI.

\subsubsection{Geração E Pré-SeleÇão de IdEIAS}

A primeira etapa do processo EMGI é a geração e pré-seleção de ideias. Normalmente é realizado em um período de três dias, e participantes vindos de todos os países da América Latina em que a empresa DuPont está presente ficam imersos para discutir sobre os desafios e as oportunidades das indústrias selecionadas (de uma a três indústrias).

Os participantes dessa etapa são funcionários especialistas nas indústrias selecionadas, funcionários com potencial de liderança e membros da liderança da empresa DuPont na América Latina. O número de participantes nessa etapa varia entre 50 e 100 pessoas e todos ficam imersos no processo durante a sua execução.

Os três dias de imersão são divididos em três etapas. A primeira etapa tem o objetivo de expandir o conhecimento e instigar a criatividade dos participantes. É realizada com a participação de clientes, consultores e especialistas nas indústrias selecionadas, e composta por palestras, vídeos e discussões. Essas atividades têm como objetivo fomentar nos participantes o pensamento sobre o estado futuro das indústrias selecionadas. 
A segunda etapa tem por objetivo promover a geração de ideias para as indústrias selecionadas. O processo de geração de ideias utiliza a metodologia denominada Futures Wheel, que foi desenvolvida por Jeremy Glenn e é uma técnica para avaliação do futuro (THE MILLENIUM PROJECT, 2012). Conforme consta no MindTools.com (2016), Jeremy Glenn desenvolveu essa técnica visual, baseada na técnica de brainstorming, com o objetivo de identificar possíveis consequências para eventos e tendências, sendo aplicada atualmente em outras áreas como processos de decisão e processos de mudança.

A metodologia do Futures Wheel é utilizada no processo EMGI para estimular a geração de ideias em diferentes rodadas, partindo da reflexão das consequências de eventos futuros nas indústrias selecionadas. Os participantes eleitos para participar são somente funcionários ou consultores formalmente contratados por meio de um contrato de confidencialidade. Esses participantes são divididos em grupos por indústria, e cada um destes tem a responsabilidade de executar a sessão de brainstorming e, ao final, decidir as ideias que serão apresentadas na etapa de pré-seleção de ideias.

Na metodologia de Futures Wheel, figura 10, a mudança ou evento futuro é colocado no centro de uma folha de flipchart. Uma vez que a mudança é estipulada, a fase de geração das consequências imediatas é iniciada. Todos os participantes são incentivados a gerar ideias das consequências imediatas e anotá-las em um post-it. Uma vez que todos os participantes concordam que terminaram a primeira fase, as ideias são lidas em voz alta, discutidas pelo grupo, modificadas ou melhoradas, e as consequências imediatas acordadas são colocadas na folha de flipchart, ao redor e conectadas à mudança ou ao evento inicial. 


\section{Figura 10 - Modelo visual da metodologia de Futures Wheel}

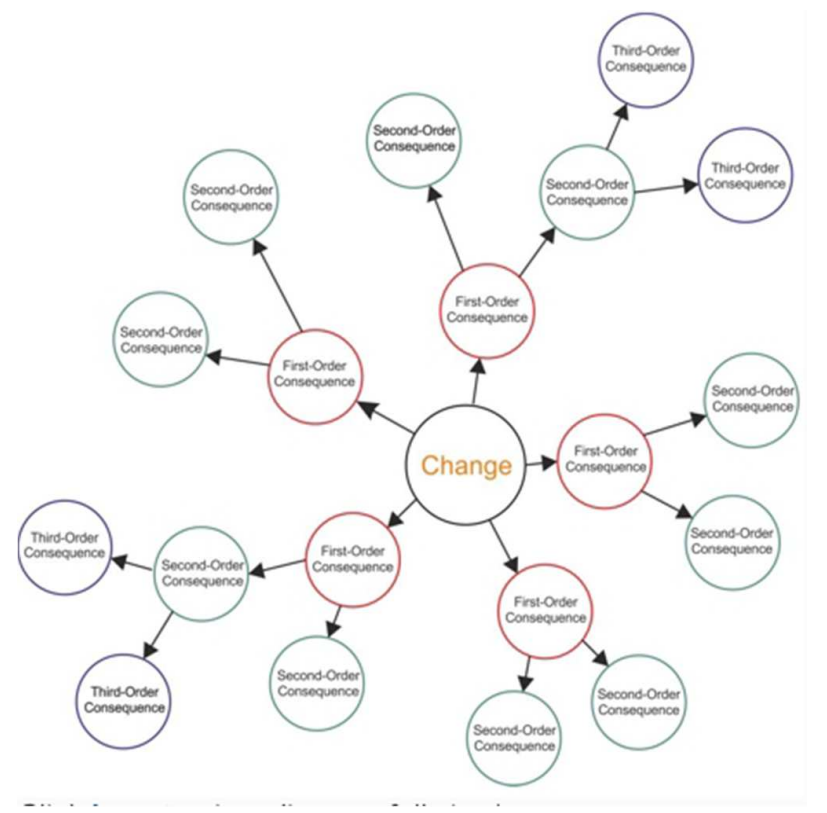

Fonte: Mind Tools (2016).

Em sequência, inicia-se uma nova rodada, em que, para cada uma das consequências imediatas, são geradas ideias. Cada rodada segue o processo descrito anteriormente, com anotação em post-its, leitura em voz alta, discussão de cada ideia e seleção de quais serão colocadas no flipchart ao redor das consequências identificadas. Rodadas subsequentes são executadas até que o grupo chegue à conclusão de que as ideias geradas no último nível possibilitam a discussão de potenciais produtos.

Para orientar o processo e garantir a participação de todos de forma ordenada, existe um facilitador para cada grupo. Cada facilitador realiza um estudo prévio da indústria selecionada para o processo de geração de ideias, como forma de se preparar para a aplicação da metodologia Futures Wheel e estimular a discussão entre os integrantes do grupo. A função do facilitador, além de orientar o processo, é permitir o livre fluxo de ideias, garantir que todos os participantes colaborem, e que as ideias não sejam criticadas, mas discutidas e melhoradas, permitindo que todos exerçam a sua criatividade. É parte da função do facilitador garantir que o processo seja seguido por todos, que não haja interferência dos participantes para pular etapas e que todos participem, independentemente de o participante ter características pessoais de introversão ou extroversão. 
Ao final do processo de brainstorming, quando o grupo, juntamente com o facilitador, concorda que há ideias suficientes para convergir, o grupo elege as ideias de que acreditam que a empresa DuPont tenha acesso ao conhecimento necessário para desenvolve las, além da tecnologia e dos produtos que permitam desenvolvê-las. De três a cinco ideias são selecionadas por grupo.

Como conclusão da segunda etapa, o grupo desenvolve, para cada ideia selecionada, um rápido estudo que inclui a descrição da ideia, o conhecimento a respeito e a tecnologia e os produtos que a empresa DuPont possui para concretizar a ideia em produto, indicando os desafios e os problemas envolvidos, uma avaliação de alto nível do potencial do mercado, os potenciais clientes e uma estimativa do tamanho da oportunidade. Cada grupo desenvolve apresentações para todas as ideias selecionadas e define um líder para a defesa de cada ideia.

A terceira e última etapa inclui a apresentação de cada ideia pelo líder selecionado a todos os participantes, mas somente o time de liderança da América Latina avalia e vota nas ideias de acordo com os critérios pré-definidos. Nessa etapa, os membros da liderança da América Latina recebem a folha com os critérios para seleção das ideias. Durante as apresentações, os líderes atribuem notas para cada um dos critérios e, ao final das apresentações, os membros da liderança da América Latina se unem para discutir os resultados da avaliação e definir por votação os projetos que seguirão para a próxima fase. A liderança da América Latina seleciona de três a seis ideias e define o líder do projeto, bem como os membros que participarão no desenvolvimento do plano de negócio de alto nível. É dado o prazo de um mês aos times para executar o plano de negócio de alto nível.

\subsubsection{Plano de Negócio de Alto Nível}

O plano de negócio de alto nível tem por objetivo refinar, para cada projeto, as suposições realizadas durante a etapa de geração e pré-seleção. O time de cada projeto tem um mês para criar o plano de negócio de alto nível que deve conter uma análise baseada no modelo SWOT ${ }^{4}$, utilizado como base para o planejamento estratégico na elaboração de um diagnóstico estratégico da empresa (HUMPHREY, 2005). O plano deve conter uma avaliação do mercado

\footnotetext{
${ }^{4}$ O termo SWOT é o acrônimo de Strenghts (Forças), Weaknesses (Fraquezas), Opportunities (Oportunidades) e Threats (Ameaças).
} 
potencial, uma análise dos concorrentes, do produto, da tecnologia existente, do preço e do canal, e uma avaliação de risco.

Uma vez completado o plano de negócio de alto nível, é agendado um workshop com duração de dois a três dias, com o objetivo de apresentar os resultados encontrados e o plano de negócio da ideia trabalhada. Para esse workshop os participantes convidados são o time de projeto, especialistas do mercado e da empresa DuPont, bem como a liderança da América Latina.

Quando os workshops de todos os projetos são concluídos, a liderança da América Latina define os projetos com melhor viabilidade e que ao mesmo tempo estejam alinhados com os princípios definidos para seleção de projetos no processo EMGI.

No total, de um até quatro projetos são selecionados nessa etapa. A liderança da América Latina valida o time de projeto e estabelece o prazo para a execução e apresentação da última fase do processo EMGI, o plano de desenvolvimento estratégico.

\subsubsection{Plano de Desenvolvimento Estratégico}

Na fase de plano de desenvolvimento estratégico é criado um plano de negócio final e o modelo de negócio. Essa fase utiliza da metodologia de Future Business History ${ }^{S M}$ (BREAKTHROUGH, 2015) para determinar como e/ou onde o novo negócio deve estar em cinco anos, e a partir disso determinam-se as etapas que são necessárias cumprir, a partir do primeiro dia do projeto, para atingir esse prazo. Nessa fase há uma ponderação sobre a viabilidade do negócio, sobre os riscos do novo negócio proposto e a determinação do caminho crítico do projeto.

Com o plano e o modelo de negócio finalizados, são realizados workshops de uma semana para rever o plano estratégico de cada projeto, estabelecer as atividades dos primeiros seis meses para cada projeto e alinhar um plano estratégico final que será submetido para aprovação de investimentos pela liderança global da empresa DuPont. 
Para cada oportunidade submetida e aprovada pela liderança global da DuPont são concedidos fundos corporativos para o desenvolvimento e a comercialização do projeto e o prazo estabelecido é de doze meses, da concessão de fundos até a comercialização do novo produto. Após esse prazo de doze meses, os fundos corporativos são removidos e a unidade de negócio que estiver liderando o projeto terá que definir investimentos próprios para terminar o projeto.

\subsection{PROBLEMÁTICA, QUESTÃO DE PESQUISA E OBJETIVOS}

Nos primeiros seis anos do processo foi constatado que seis produtos de sucesso foram lançados no mercado. É importante destacar que sucesso para a organização é definido como os produtos que foram lançados e geraram valor esperado, Desde então ocorreu a diminuição de ideias que possuíam as características que permitissem o desenvolvimento sob o processo EMGI. Finalmente, em 2015, tal processo foi suspenso e o foco dos negócios se voltou para o processo de inovação aplicado nos Centros de Inovação.

A participação da pesquisadora em um ciclo do processo EMGI levou ao questionamento de quais fatores podem ter influenciado o desempenho do processo, com foco específico na etapa de geração de ideias. Nessa fase, a pesquisadora questiona o método utilizado para estimular a geração de ideias e a composição dos participantes como fatores que podem interferir no resultado para obter a próxima ideia excepcional.

Em relação ao método de geração de ideias, o desempenho do indivíduo em uma sessão de brainstorming pode ser afetado por diversos motivos, como acomodação, apreensão e bloqueio (DIEHL; STROEBE, 1987). Em relação aos participantes, empresas tradicionais esperam que seus times de engenheiros e cientistas internos gerem suas próprias ideias (BAYUS, 2013). Entretanto, estudos empíricos, como o de Poetz e Schreier (2012), demonstram que, após um certo ponto, a exploração de conhecimento interno reduz e acarreta em um arrefecimento na geração de ideias para novos produtos. Pesquisas sugerem que a maneira com que ideias inovadoras são geradas sofre mudanças de paradigma e que há um grande potencial de ideias externas à empresa a ser explorado (CHESBROUGH, 2003). 
Tendo como base a etapa de geração de ideias do processo EMGI executado pela empresa DuPont na América Latina, definiu-se como problema de pesquisa desta dissertação: como melhorar o processo de geração de ideias para o desenvolvimento de novos produtos em uma grande organização multinacional?

O objetivo desta dissertação é analisar como o processo de geração de ideias do processo EMGI foi executado na empresa DuPont, visando apresentar soluções ou melhorias nesse processo.

Como objetivos específicos tem-se:

a) estudar processos de inovação com foco na etapa inicial de geração de ideias;

b) identificar alternativas aplicadas para melhorar a qualidade das ideias geradas através dos participantes engajados no processo; e

c) identificar sugestões para melhorar o método aplicado para geração de ideias.

Para atingir os objetivos desta dissertação foi executada uma análise em profundidade do referencial teórico que está apresentado no capítulo a seguir. 


\section{REFERENCIAL TEÓRICO}

Inovações têm sua origem em ideias que, ao serem desenvolvidas, se materializam em novos processos, produtos e métodos que agregam valor (KNIGHT, 1967; AMABILE, 1988; VAN DE VEN, 1986; GURTEEN, 1998; BJORK; MAGNUSSON, 2009). Para as organizações não basta uma ideia ser original, ela tem que ter aplicabilidade e utilidade (AMABILE, 1998). Para que sejam considerados como inovadores, novos produtos, processos ou métodos organizacionais ou de marketing precisam possuir um nível de novidade ainda não existente em uma organização, em um mercado, ou ser totalmente novos mundialmente (OECD, 2005). Inovação não se restringe somente ao desenvolvimento de um processo, produto ou método totalmente novo, inclui também a aplicação de algo já existente de forma inovadora e a modificação ou melhoria das características de produtos já existentes, de forma que incremente as suas funcionalidades.

Cooper e Kleinschmidt (1993) listam sete categorias de inovação conforme o seu grau de novidade em relação à empresa, ao mercado e ao mundo: produto totalmente novo que cria um novo mercado, um produto totalmente novo comercializado em um mercado já existente, um produto novo para uma empresa que possui características adicionais aos produtos similares de competidores, uma nova linha de produto que possui produtos similares de competidores, um novo item em uma linha de produto já existente, modificações significantes em um produto já existente e modificações menores em um produto já existente.

Organizações desenvolvem vários tipos de inovação para se manterem competitivas e estabelecem seus processos, sua estrutura organizacional e sua alocação de recursos de acordo com o tipo de inovação desenvolvida. A inovação incremental foca em desenvolver pequenas melhorias em um produto comercializado com o objetivo de agregar maior valor à base de clientes já existente e permitir que uma organização extraia maior retorno financeiro a partir de um desenho de produto ou processo estabelecido (ETTILE; BRIDGES; O'KEEFE, 1984; HENDERSON; CLARK, 1990; CLARK; WHEELWRIGHT, 2010; O’REILLY III; TUSHMAN, 2004). Inovação radical ocorre quando uma organização explora um campo da ciência ou processo e desenvolve algo totalmente novo, permitindo novas aplicações ou a criação de um novo mercado que afeta de forma radical uma indústria e suas organizações, 
podendo criar um novo padrão no mercado (ETTILE; BRIDGES; O'KEEFE, 1984; HENDERSON; CLARK, 1990; CLARK; WHEELWRIGHT, 2010; O'REILLY III; TUSHMAN, 2004). Inovação de arquitetura ocorre quando um produto ou processo tem um de seus componentes modificados e dessa forma faz com que toda a arquitetura seja reconfigurada de forma a conectar os existentes componentes de uma nova maneira, podendo criar um novo desenho dominante para um produto já existente (HENDERSON; CLARK, 1990; O'REILLY III; TUSHMAN, 2004). Clark e Wheelright (2010) identificam também a inovação de plataforma, que representa o desenvolvimento da próxima geração de um produto. A inovação de plataforma parte da agregação de diversas mudanças, adicionando ou subtraindo funcionalidades a um produto ou processo, com o objetivo de atender às necessidades de uma base maior de clientes e fornecendo ao cliente um caminho de transição para a nova geração.

Outra forma de categorizar a inovação foi elaborada por Clayton Christensen (2000), que identificou por meio de seus estudos empíricos a inovação disruptiva. Na inovação disruptiva um novo produto é desenvolvido por uma empresa com menos recursos, apresentando, inicialmente, preço, desempenho e funcionalidades inferiores em comparação aos produtos que dominam o mercado e destina-se a um segmento de mercado normalmente negligenciado pelos principais produtos. É conceituada como disruptiva quando o produto inicial se desenvolve e atinge um nível de sofisticação que atrai clientes tradicionais do mercado e estes migram o seu volume de consumo para o produto disruptivo, levando empresas tradicionais a perderem sua posição no mercado. Em contraponto à inovação disruptiva encontra-se a inovação de sustentação, que tem como foco melhorar o desempenho de produtos existentes nas dimensões que são valorizadas pelos atuais clientes (CHRISTENSEN, 2000; CHRISTENSEN; RAYNOR; MCDONALD, 2015).

Organizações que definem sua estratégia de renovação focando em múltiplos tipos de inovação podem adotar diferentes formas de gerenciamento, conforme o tipo estabelecido (O'REILLY III; TUSHMAN, 2004; BESSANT et al.; 2005). Mas, independentemente dos tipos de inovação em que uma organização concentre as suas atividades de pesquisa e desenvolvimento, as empresas necessitam ter a habilidade de identificar e selecionar as melhores ideias que permitam a execução de sua estratégia de inovação. Sendo a ideia o ponto inicial para a inovação, o fluxo contínuo de ideias (COOPER, 1988; COOPER; EDGETT; KLEINSCHMIDT; 2002; BOEDDRICH, 2004), a qualidade das ideias (COOPER, 1988) e a existência de um processo de inovação para coletar, avaliar e desenvolver essas ideias em 
produtos, processos ou métodos tornam-se críticos para a sustentabilidade e competitividade de uma organização (UTTERBACK, 1970; COOPER, 1988).

\subsection{PROCESSOS DE INOVAÇÃO}

O estudo de Utterback (1970) identifica três fases do processo de inovação: geração de ideias, solução do problema e implementação e difusão. No processo de geração de ideias origina-se o desenvolvimento de um conceito por intermédio da agregação de diferentes porções do conhecimento sobre tecnologia, comportamento de mercado, questões políticas e sociais visando resolver um problema. Na solução do problema acontece a invenção, ou seja, o desenho técnico da solução. Na etapa de implementação e difusão ocorre o desenvolvimento do produto e o lançamento deste no mercado. É nessa última etapa que um novo produto pode se tornar uma inovação.

A necessidade de se estabelecer um modelo de processo disciplinado de desenvolvimento de novos produtos foi identificada por Cooper e Kleinschmidt (1986) como fator determinante de sucesso. Estudos subsequentes de Cooper (1988) estabelecem três grandes fases do processo de inovação: pré-desenvolvimento, desenvolvimento de produto e comercialização. $\mathrm{O}$ autor destaca a necessidade de dedicar recursos e estabelecer um processo de inovação estruturado para todas as fases do processo, inclusive para a fase de pré-desenvolvimento, de forma a aumentar as chances de sucesso de um novo produto.

Boeddrich (2004) identifica dois grandes estágios do processo de inovação. No primeiro estágio ocorrem geração, análise, triagem e seleção de ideias, e a decisão de quais ideias se tornarão projetos de inovação. Esse primeiro estágio é caracterizado pelo uso maior de recursos intelectuais, sendo que quanto melhor a qualidade da informação obtida para a definição da ideia, melhores são os resultados dos projetos selecionados. O segundo estágio é caracterizado pela predominância do uso de recursos tangíveis e é quando ocorre o desenvolvimento e o lançamento dos produtos, processos ou métodos inovadores. Ambos os estágios devem ser estruturados, mas especialmente o primeiro, de forma a obter informações relevantes às ideias propostas, permitindo uma melhor tomada de decisão e redução das incertezas. 
Cooper (2001, 2008), baseado em seus estudos empíricos, estabelece um processo de inovação disciplinado denominado Stage-Gate ${ }^{\circledR}$. Nesse processo, as empresas seguem uma sequência de estágios e pontos de decisão como forma de garantir que as atividades importantes sejam desenvolvidas e que após cada estágio os patrocinadores do projeto possam decidir se ainda há um negócio para seguir em frente ou não. O Stage-Gate®é composto por sete etapas. A etapa inicial, chamada de descobrimento é a etapa em que ocorre a geração de ideias. Após o descobrimento ocorre os cinco estágios e cinco gates formados por: definição de escopo, criação de business case, desenvolvimento de produto, testes e validação do produto e lançamento do produto. E a etapa final, após o lançamento do produto onde se realiza a revisão pós-lançamento do produto (COOPER, 2008).

Similar aos estudos de Cooper (1988), o estudo de Koen, Bertels e Kleinschmidt (2014a) apresentam as mesmas três fases do processo de inovação, mas qualifica a etapa de prédesenvolvimento como Front End of Innovation (FEI). Enquanto todas as fases são importantes, estudos empíricos identificam a fase de pré-desenvolvimento como crítica para todo o processo de inovação. A geração e seleção das ideias que são desenvolvidas nessas etapas são de alto impacto para o sucesso da inovação (HERSTATT; VERWORN, 2001; KOEN et al., 2001; COOPER; EDGETT; KLEINSCHMIDT, 2002; REID; BREITANI, 2004).

\subsubsection{PRÉ-DESENVOLVIMENTO OU FrontEND OF INNOVATION (FEI)}

A etapa de pré-desenvolvimento ou FEI, também referenciada por outros autores como Fuzzy Front End (KOEN et al., 2002; KIM; WILEMON, 2002; GASSMANN; SCHWEITER, 2014; GAUBINGER; RABI, 2014) é o estágio que engloba as atividades de definição das ideias que serão desenvolvidas em um novo produto ou processo, e é apontado como uma etapa que organizações conduzem de forma não estruturada dentro do processo de inovação (KOEN et al., 2001; KIM; WILEMON, 2002; GASSMANN; SCHWEITZER, 2014). Há organizações que acreditam que estruturar o FEI pode coibir a criatividade dos participantes (BOEDDRICH, 2004). Khurana e Rosenthal (1998) apontam que organizações bem-sucedidas no processo de inovação conectam as estratégias de negócio e estratégia de produtos com o desenvolvimento de produto em um processo formal de execução do FEI. Enquanto autores apontam a necessidade de um processo formal, este precisa ser flexível (KHURANA; ROSENTHAL; 
1997), permitindo atividades em paralelo e interações entre as etapas para diminuir as incertezas dessa fase (COOPER, 2008; KOEN et al.; 2001; GAUBINGER; RABI, 2014). Há a necessidade de estruturar o FEI e encontrar o balanço correto entre flexibilidade e criatividade, de um lado, e estrutura e burocracia, do outro, estabelecendo forma ao processo sem inibir a criatividade (GAUBINGER; RABI, 2014).

As atividades do FEI podem ser ordenadas em três estágios, a saber: estágio 1 - geração e seleção de ideias; estágio 2 - investigação inicial para verificar a possibilidade da ideia, incluindo avaliação de mercado, técnica e financeira; estágio 3 - definição do conceito do produto a partir da ideia, executando o desenvolvimento do conceito, o teste e a avaliação para obter ou não a aprovação para seguir para o desenvolvimento de produto (COOPER, 1988). Gassmann e Schweiter (2014) definem as fases da etapa de FEI como: identificação das necessidades latentes dos consumidores, antecipando as necessidades e desejos de clientes e usuários, geração de ideias, avaliação das mesmas, desenvolvimento do conceito do produto, e avaliação do conceito desse produto.

As fases também podem ser distintas conforme o tipo de inovação. Koen, Bertels e Kleinschmidt (2014b) diferenciam as fases entre os tipos de inovação incremental e radical. Para a inovação incremental, os autores identificam cinco constructos: identificação e análise da oportunidade, geração de ideias, avaliação das ideias, seleção das ideias e definição do conceito. Para a inovação radical, os autores identificam oito constructos:avaliação do desempenho, identificação de oportunidade baseada em tendências macroeconômicas, culturais, demográficas e regulatórias; identificação de oportunidades disruptivas para a sua área de atuação; análise de oportunidades por meio de ferramentas, como planejamento baseado em cenários; análise de oportunidades por meio de análise competitiva e probabilidade de sucesso de mercado; geração de ideia com a utilização do método de etnografia; geração de ideias baseada em novas tecnologias ou invenções tecnológicas, e desenvolvimento de um plano de negócio.

Independentemente do modelo selecionado, à medida que se progride nas fases do FEI, as incertezas técnicas e de mercado vão diminuindo (GASMANN; SCHWEITER, 2014). Reduzir a ambiguidade sobre a qualidade da ideia é importante parte do processo, evitando-se descartar ideias com grande potencial prematuramente (KIM; WILEMON, 2002). Outro fator crítico durante a execução das fases do FEI é a participação ativa dos gestores para que eles estejam 
capacitados para selecionar e investir em ideias que tenham maior probabilidade de sucesso (BACON et al., 1994; KHURANA; ROSENTHAL, 1998; KIM; WILEMON, 2002; GASSMANN; SCHWEITZER, 2014; KOEN; BERTELS; KLEINSCHMIDT, 2014a). Podese também, na fase de FEI, incluir os clientes (GOLDENBERG; LEHMANN; MAZURSKY, 2001; KIM; WILEMON, 2002) para identificar soluções nas oportunidades que atendam às suas expectativas.

Nas fases do FEI é mais fácil e menos custoso influenciar e modificar as decisões tomadas do que na fase de desenvolvimento de produto (GASSMANN; SCHWEITER, 2014). Segundo Dolan (1993, apud GOLDENBERG; LEHMANN; MAZURSKY, 2001), é importante que as organizações identifiquem potenciais falhas nas ideias selecionadas o mais cedo possível, de preferência antes do início da etapa de desenvolvimento, pois quanto mais avançado no processo de inovação, maior o investimento realizado. Além de evitar investimentos extras, deve-se focar nas fases iniciais para refinar o conceito de uma ideia minimizando o retrabalho nas etapas seguintes (GASSMANN; SCHWEITER, 2014).

\subsection{GERAÇÃO DE IDEIAS}

A ideia é a solução inicial, ainda que embrionária, de um problema (BOEDDRICH, 2004; KOEN; BERTELS; KLEINSCHMIDT, 2014b). Gurteen (1998) define: “An idea is simply 'something' that is unrealized, unproven or untested', ou seja, pode ser algo totalmente novo ou algo já existente, transformado por um novo conhecimento ou pela nova aplicação de um conhecimento já existente. Ao gerar ideias, indivíduos ou grupos de indivíduos exercem a sua criatividade e identificam possibilidades que possam ser desenvolvidas para trazer inovação a uma organização (AMABILE, 1988; GURTEEN, 1998), no entanto, uma ideia demonstra a sua utilidade somente quando gera valor, após o seu desenvolvimento e comercialização (KNIGHT, 1967; GURTEEN, 1998; VAN DEVEN, 1986). Pesquisas na psicologia cognitiva suportam a noção de que o conhecimento dos indivíduos, participando do processo de geração das ideias, interfere na riqueza da ideia, ou seja, quanto maior o conhecimento do indivíduo no domínio explorado, mais esse indivíduo tem a capacidade de rearranjar os elementos do seu

\footnotetext{
${ }^{5}$ Tradução livre da autora: "Uma ideia é simplesmente 'algo' que ainda não foi realizado, provado ou testado."
} 
conhecimento e gerar ideias alternativas (AMABILE, 1988). Ideias surgem da aplicação do conhecimento de forma criativa. O sucesso em processos de inovação demanda a criação de uma cultura organizacional em que estratégia, estrutura organizacional, mecanismos de reconhecimento e prêmios, e comportamentos incentivem à criatividade (MARTINS; TREBLANCHE, 2003).

A etapa de geração de ideias é o momento em que se busca encontrar a forma inicial de um produto ou serviço para solucionar um problema, e trata-se de um processo evolucionário no qual ideias são construídas, modificadas e combinadas até se chegar à maturidade de uma ideia que entra em um processo de seleção (KOEN et al., 2002). Utterback (1970) define essa etapa como o momento em que uma necessidade ou uma tecnologia é identificada como uma oportunidade e o desenho de um produto é criado. Cooper (1998) identifica a geração de ideias como a etapa em que ocorre a concepção de uma ideia de produto. Boeddrich (2004) indica a necessidade de adoção de um processo sistematizado para permitir a captura contínua de ideias, e para potencializar as oportunidades de uma organização em gerar inovação de valor.

Para a execução da etapa de geração de ideias, as organizações podem adotar diferentes ferramentas, técnicas ou métodos para estimular a criatividade e coletar e compartilhar ideias. Entre as técnicas sugeridas estão sessões de brainstorming, caixa de sugestões (COOPER, 1988; KOEN et al., 2002), concursos (COOPER, 1998) etc.

Há autores que identificam a diversificação dos participantes envolvidos na etapa de geração de ideias para enriquecer o conhecimento envolvido. Cooper, Edgett, Kleinschmidt (2002) indicam ser interessante o engajamento de clientes, direta ou indiretamente, no processo, e a utilização de lead users (HERSTATT; VERWORN, 2001). Hansen e Birkinshaw (2007) identificam três grupos de participantes na geração de ideias: times internos de uma área de negócio, colaboração entre unidades de negócios e grupos externos. Os autores concluem que a melhoria da qualidade da ideia ocorre quando as organizações adotam a colaboração entre unidades de negócios e times externos. Para Koen e colaboradores (2002), também é importante a interação com clientes e a colaboração de times multifuncionais na etapa de geração de ideias. Os autores acrescentam, ainda, a colaboração com outras empresas e instituições como alternativas adicionais de participantes. 
A adoção de ferramentas, técnicas e métodos, agregada com a diversificação dos participantes, busca aumentar a qualidade das ideias geradas. E isso é mais relevante para o processo de inovação do que o número total de ideias, pois as empresas estão em busca da ideia excepcional que vai estabelecer vantagem competitiva (BJORK; MAGNUSSON, 2009; GIROTRA; TERWIESCH; ULRICH, 2010; HIRUNYAWIPADA; PASWAN; BLANKSON, 2015).

Os processos organizacionais utilizados na etapa de geração de ideias são estudados por duas disciplinas: pela psicologia social e pelo gerenciamento de inovação. A psicologia social estuda o método de brainstorming como forma de alavancar ideias inovadoras. Em gerenciamento da inovação se estudam os resultados da inovação e as formas organizacionais (GIROTRA; TERWIESCH; ULRICH, 2010). Para efeitos deste estudo, o foco será no método de brainstorming, que está apresentado a seguir.

\subsubsection{MÉtodo BRAINSTORMING}

O método de brainstorming, disseminado por Osborn (1957, apud DIEHL; STROEBE, 1987), encoraja a participação dos membros de um grupo na geração de ideias, estabelecendo regras que permitam a livre contribuição de todos os participantes. As regras aplicadas no método de brainstorming são: livre fluxo de ideias, pois quanto mais ideias melhor; ideias diferenciadas, inovadoras e ousadas; autonomia para melhorar e combinar as ideias apresentadas; e não criticar ou rejeitar nenhuma ideia. De acordo com Osborn, a aplicação desse método de gerar ideias em grupos aumenta a produtividade dos indivíduos em comparação ao processo de geração de ideias individuais. Entretanto, estudos empíricos contestam essa afirmação (BOUCHARD; HARE, 1970; DIEHL; STROEBE, 1987; MULLEN; JOHNSON; SALAS, 1991; PAULUS; YANG, 2000).

O desempenho individual em uma sessão de brainstorming pode ser afetado por três motivos: acomodação quando o resultado é medido pelo grupo, não pelo desempenho individual; apreensão pelo julgamento, quando as pessoas se inibem em expressar suas ideias com receio de serem julgadas pelos outros participantes; e bloqueio de produção, que ocorre quando as pessoas têm que esperar uma pessoa terminar de falar para expressar suas ideias (DIEHL; STROEBE, 1987). Nos estudos de Janis (1982, apud GIROTRA; TERWIESCH; ULRICH, 
2010) identificou-se a pressão subconsciente para os participantes se conformarem uns com outros. Há diferentes opiniões sobre a eficácia do brainstorming como forma de propiciar um ambiente que permita a identificação da ideia excepcional que gere impacto no mercado como uma inovação radical (GIROTRA; TERWIESCH; ULRICH, 2010). Os estudos de Kavadias e Sommer (2009), por exemplo, concluíram que o método de brainstorming, quando aplicado para solução de problemas complexos que envolvam múltiplas disciplinas entre diferentes domínios do conhecimento, apresenta ideias com qualidade inferior. Diehl e Stroebe (1987) concluíram que na geração de ideias, indivíduos trabalhando sozinhos podem ser mais produtivos que em grupos. Sutton e Hagardon (1996), no entanto, argumentam que o uso do brainstorming pode trazer benefícios adicionais para os participantes e para a empresa, e que a efetividade do brainstorming não deve considerar somente o volume e qualidade das ideias como métricas de sucesso da aplicação do método.

Estudos de Paulus e Yang (2000) confirmam que uma alternativa para aumentar a produtividade em brainstorming é aplicar a técnica do brainwriting, técnica na qual os participantes da sessão do brainstorming escrevem de duas a quatro ideias em um papel e, posteriormente, leem essas ideias aos outros participantes. Os autores argumentam que, por meio dessa técnica, a produtividade do grupo é comparável ou superior à produtividade na geração de ideias por indivíduos sozinhos. Há também a sugestão de alternar sessões em grupo com sessões individuais, concedendo aos participantes um período de incubação, o que permitiria que cada um refletisse sobre as ideias geradas nas sessões em grupos, agregando o seu conhecimento e com isso gerando ideias adicionais (PAULUS; BROWN, 2007).

Gurteen (1998) argumenta que ser criativo vai além de estimular ou participar de sessões de brainstorming, e defende que os indivíduos precisam incentivar a criatividade em cada interação e, dessa forma, transformar em hábito a habilidade de inovar. Esse autor defende que o diálogo é uma das principais ferramentas para desbloquear a criatividade e define o diálogo como um processo de ganha-ganha, em que as partes escutam umas às outras, aprendem a partir dessa interação e exercem sua criatividade sem receios de serem julgadas.

O processo EMGI utiliza a técnica do Future Wheels, que permite a realização do método de brainstorming de forma estruturada. Nessa técnica os participantes escrevem as suas ideias para cada fase do processo e, posteriormente, o facilitador lê as ideias identificadas para compartilhar 
e estimular a criatividade para a fase seguinte. Baseados nesse método e nos princípios do processo EMGI, que requerem que as ideias sejam multinegócios, estabelece-se:

Proposição 1: A técnica utilizada para gerar ideias limita a geração de ideias inovadoras em situações que requerem conhecimento de múltiplas áreas de negócios.

\subsubsection{PARTICIPANTES DA FASE DE GERAÇÃo DE IDEIAS}

Para gerar ideias é necessário que os participantes apliquem a criatividade, que inclui inventar novas formas de resolver um problema, aplicar o conhecimento, a técnica e o talento no domínio do conhecimento, além de estar motivado, fatores que podem ser intrínsecos ou extrínsecos ao processo (AMABILE, 1998). Segundo Amabile (1998), indivíduos intrinsecamente motivados aumentam as chances de gerar ideias inovadoras. Ford (1990, apud MCADAM; MCCLELLAND, 2002) indica que o pensamento criativo pode ser estimulado nos participantes com a aplicação de técnicas como o brainstorming.

Ao aplicar a técnica de brainstorming ou suas variações é importante observar as características dos participantes. King e Anderson (1995, apud MCADAM; MCCLLEAND, 2002) destacam que o grupo precisa ser heterogêneo para a geração de ideias e também salientam que grupos de curta duração são mais criativos. A repetição de participantes e a conformidade entre os participantes, portanto, podem ser fatores inibidores de novas ideias. A habilidade de identificar a melhor ou as melhores ideias pode ser limitada pelo engajamento de ter os mesmos participantes, pois cria uma dependência entre a ideia gerada pelo grupo e a sua história (GIROTRA; TERWIESCH; ULRICH, 2010).

Os participantes do processo de brainstorming podem sofrer influências de outros participantes que coíbem a efetividade do processo. Participantes de processos de geração de ideias podem também sofrer o efeito de fixação cognitiva, ou seja, o sucesso de uma ideia anterior gera efeito no autor de continuar sugerindo ideias similares, não explorando todo o potencial do seu domínio de conhecimento e produzindo uma ideia menos original (BAYUS, 2013). 
É natural para muitas organizações buscarem ideias internamente, normalmente dentro da sua própria área, restringindo o acesso a grupos de outras unidades ou a busca por ideias em fontes externas às empresas (HANSEN; BIRKINSHAW, 2007). A inclusão de ideias externas às organizações ao processo de inovação é um fenômeno recente, que se tornou mais proeminente a partir da década de 1990 (GASSMANN, 2006). As mudanças na tecnologia de informação e comunicações (GASSMANN, 2006; GASSMANN; ENKEL; CHESBROUGH, 2010) possibilitaram o acesso ao conhecimento para a solução de problemas e o desenvolvimento de soluções, ao eliminar barreiras físicas. A internet, que se tornou predominante tanto na vida profissional quanto pessoal dos indivíduos, permitiu a aproximação das organizações aos seus consumidores, universidades e outras organizações, permitindo a disseminação da inovação aberta.

A inovação aberta se apresenta, portanto, quando as empresas abrem o seu processo de inovação e alavancam a circulação de ideias entre diferentes atores, externos às organizações, como forma de potencializar os seus resultados (CHESBROUGH, 2003; GASSMANN, 2006). A inovação aberta se apresenta como contraponto à inovação fechada, identificada como a inovação praticada por organizações que se declaram autossuficientes em seus processos de criação, buscando adquirir e manter todo o conhecimento necessário para inovar internamente. Empresas que apresentam a inovação fechada restringem a participação de fontes externas de conhecimento ao processo de inovação e executam todo o processo, desde a geração de ideias até a comercialização, com seus times internos de engenheiros e cientistas. DuPont, IBM e Xerox são citadas como exemplos de grandes corporações com altos investimentos em pesquisa e desenvolvimento, e com processo de inovação fechado. Exemplos na indústria da Tecnologia da Informação demonstraram que as empresas, para serem bem sucedidas, não são obrigadas a manter um processo fechado de inovação para deter a dominância no mercado (CHESBROUGH, 2003).

O conceito da inovação aberta se baseia, portanto, no volume imensurável de conhecimento disponível em recursos externos à organização. Aplicando a inovação aberta, as organizações podem trazer ideias e conhecimentos externos para trabalhar internamente com suas equipes de P\&D e gerar inovação de valor. O conceito de inovação aberta tem como princípio: "if we make the best use of internal and external ideas, we will win"6 (CHESBROUGH, 2003, p. xxvi).

\footnotetext{
${ }^{6}$ Tradução livre da autora: "se fizermos o melhor uso de ideias internas e externas, nós iremos vencer."
} 
Fontes externas de conhecimento podem ser exploradas e as organizações têm a opção de utilizar tanto fontes de ideias internas quanto externas para avançar a sua agenda de inovação (CHESBROUGH, 2004). Ao explorar a inovação aberta como forma de ampliar as oportunidades para inovação, as organizações podem escolher a forma mais apropriada de incluir atores externos no seu processo de inovação (GASSMANN; SANDMEIER; WELCHT, 2006). Gassmann (2006) aponta estudos que exploram a inovação aberta sob as perspectivas de globalização da inovação, integração antecipada de fornecedores, outsourcing de P\&D, inovação pelo usuário e comercialização externa e aplicação de tecnologia.

Gassmann, Enkel e Chesbrough (2010) apresentam que as organizações devem equilibrar atividades de inovação aberta e inovação fechada com o objetivo de proteger suas competências e propriedade intelectual, ao mesmo tempo em que agilizam os seus ciclos de inovação para enfrentar os seus competidores.

Segundo Poetz e Schreier (2012), a aproximação com clientes para definir a solução de um problema específico ainda é controversa, mas as empresas têm adotado práticas de engajamento de clientes como parte do processo de inovação aberta. Ferro (2010) explica que o engajamento de clientes é uma prática importante dentro do modelo de inovação aberta, destacando que pesquisas empíricas categorizam esse tipo de engajamento em três categorias: comunidades de usuários em geral, que trabalham em conjunto para um objetivo comum; criação colaborativa e de geração de ideias; e comunidades e redes virtuais na geração de inovação.

Chesbrough (2004) categoriza a inclusão de clientes e comunidades de clientes na inovação aberta de outside-in, ou seja, busca-se trazer recursos de fora da empresa para colaborar com o processo de inovação. Prahalad e Ramaswamy (2004) argumentam que as organizações devem proporcionar experiências que facilitem a cocriação entre consumidores e seus times internos de inovação, de forma que essa interação seja a base para a definição e a entrega de valor. Uma forma de engajamento de clientes na geração de ideias pode ocorrer por meio da participação de lead-users (VON HIPPEL, 2005; LILIEN et al., 2002). Para Von Hippel (1986) lead-users são os usuários que estão à frente do seu tempo, identificando e elaborando soluções que atendam a sua necessidade e que podem se tornar o padrão do mercado no futuro. Boudreau e Lakani (2013) vão mais além e sugerem uma alternativa mais abrangente para engajamento de consumidores, através do acesso a crowds por meio da internet para a solução de problemas complexos. Segundo Kozinets, Hemetsberger e Schau (2008), crowds é definido como um 
grupo online composto por um alto número de participantes que se juntam para executar uma atividade específica. É o objetivo comum que os atrai, e eles mantêm o senso de propósito e a participação até que o objetivo seja completado. Após o final da atividade, o grupo se separa. King e Lakhani (2013) apontam o uso de torneios de inovação como forma de obter ideias com o uso de crowds. Terwiesch e Xu (2008) explicam que "In an innovation contest, a firm (the seeker) facing an innovation-related problem (e.g., a technical $R \& D$ problem) posts this problem to a population of independent agents (the solvers) and then provides an award to the agent that generated the best solution."7

A importância da inclusão de clientes nos processos organizacionais é constatada pela pesquisa realizada pela IBM (2013), que aponta que 55\% dos líderes sêniores das empresas respondentes indicam que irão colaborar mais com os seus clientes, indo além do processo de desenvolvimento de produtos, engajando os clientes na definição da estratégia de negócio.

No processo EMGI, a fase de geração de ideias era executada com a participação predominantemente de funcionários, mantendo um time fixo de participantes, sendo o time variável composto de funcionários com potencial de serem futuros líderes da organização e especialistas na indústria explorada. Ocasionalmente clientes, consultores e especialistas participavam desta fase. Baseados na composição dos participantes do processo, estabeleceram-se as seguintes proposições:

Proposição 2: A repetição dos participantes na geração de ideias afeta a geração de ideias inovadoras.

Proposição 3: A participação restrita a funcionários limita o conhecimento do grupo na geração de ideias.

Se uma empresa tem a habilidade de estimular, capturar e avaliar ideias, essa organização aumenta o seu potencial de identificar ideias de qualidade que podem trazer diferenciação no mercado. A busca pelo conhecimento do processo de inovação, suas fases e, especificamente,

\footnotetext{
${ }^{7}$ Tradução livre da autora: "Em um torneio de inovação, a empresa (buscadora) que está enfrentando um problema relacionado com inovação (por exemplo, um problema técnico de $\mathrm{P} \& \mathrm{D}$ ) coloca este problema para um grupo de agentes independentes (solucionadores) e, então, fornece um prêmio para o agente com a melhor solução."
} 
um entendimento em profundidade da fase de geração de ideias visam explorar alternativas de como essa fase pode ser mais eficiente nas organizações. 


\section{PROCEDIMENTOS METODOLÓGICOS}

Este estudo visa analisar como a etapa de geração de ideias do processo EMGI para desenvolvimento de novos produtos está sendo desenvolvida na empresa DuPont, visando apresentar soluções e/ou melhorias nesse processo.

A proposta de pesquisa surgiu da curiosidade da pesquisadora em entender, dentro do processo de inovação, a fase de geração de ideias, especialmente por essa fase ser o ponto de partida da inovação.

Para atender ao objetivo desta dissertação selecionou-se como método de pesquisa o estudo de caso único, com finalidade exploratória, porque visa à descoberta e ao entendimento pela pesquisadora dos fatores que podem ou não afetar a organização estudada (HAIR et al., 2005). Gil (1987) destaca que a pesquisa exploratória é aplicada incialmente para auxiliar o pesquisador a tornar um problema mais explícito para auxiliá-lo na definição do que irá estudar.

Segundo Yin (2010), os estudos de casos são apropriados quando se busca responder "como" processos organizacionais e fenômenos complexos são relacionados à avaliação de eventos contemporâneos em profundidade. Martins e Theóphilo (2007) destacam que se trata de uma investigação em profundidade dentro do contexto real do fenômeno, ou seja, o pesquisador não interfere ou controla o ambiente, e sua função é observar, inquerir e levantar dados que permitam compreender e interpretar um fenômeno. Para Yin (2010), trata-se da investigação de um fenômeno contemporâneo no seu contexto de vida real, e se não há uma clara divisão entre o fenômeno e o contexto, o estudo de caso é o seu melhor método de pesquisa.

Da mesma forma, Gil (1987, p. 37) define estudo de caso como "estudo profundo e exaustivo de um ou poucos objetos, de maneira que permita seu amplo e detalhado conhecimento". O caso selecionado trata da investigação de um específico processo de inovação em uma empresa de manufatura reconhecida mundialmente como uma das líderes na área de inovação, com o intuito de obter compreensão sobre a experiência da fase de geração de ideias. A unidade de pesquisa foi escolhida pelo acesso da pesquisadora aos dados primários e secundários do processo de inovação dessa organização e aos participantes do processo. 
A coleta de dados secundários foi executada a partir da obtenção de informações e documentos dos processos de inovação, pelo acesso ao banco de dados da empresa, a notícias e matérias publicadas em revistas, jornais, e ao site da empresa. A coleta de dados primários utilizou a abordagem de pesquisa qualitativa, com a adoção de entrevistas em profundidade, e a observação direta. Hair (2005, p. 152) destaca que "as abordagens qualitativas para coleta de dados são usadas tipicamente no estado exploratório do processo de pesquisa". Hair (2005) indica para os estudos exploratórios que a coleta seja obtida com dados narrativos por meio de entrevistas e observação de comportamento.

Cronologicamente, a observação direta foi realizada em 2010, anterior ao início desta pesquisa. A observação ocorreu pois a pesquisadora estava diretamente envolvida no processo de geração e pré-seleção de ideias. No primeiro dia desse processo ocorreu a participação em palestras e discussões sobre os mercados de atuação para instigar a curiosidade sobre os mercados e suas oportunidades, o que permitiu abrir os horizontes dos participantes para iniciar o processo criativo. No segundo dia, os participantes foram divididos em grupos, e para cada grupo foi especificado um mercado e um facilitador que orientava a aplicar o método de Futures Wheel. Desse processo, duas ideias foram selecionadas e desenvolvidas para apresentação no processo de pré-seleção. A participação ativa da pesquisadora ocorreu durante a fase de brainstorming e no auxílio do desenvolvimento da ideia para que esta fosse apresentada para seleção. A experiência em participar desse processo a instigou a investigar qual processo de geração de ideias seria o ideal para permitir o processo criativo dos participantes, levando a pesquisadora a questionar a técnica utilizada e a composição dos participantes. A dúvida recaía especialmente sobre se deveria ou não ser aberto o processo de geração de ideias para a participação de agentes externos à empresa.

A observação do processo de geração e pré-seleção de ideias, reunida aos dados secundários e teóricos levantados durante os anos de 2014 e 2015, permitiram a criação do instrumento de pesquisa para a realização de entrevistas em profundidade com outros participantes desse processo. A estrutura do instrumento de pesquisa foi baseada nos três estágios do processo de inovação definidos por Cooper (1998): geração e seleção de ideias; pesquisa inicial para verificar a efetividade da ideia, incluindo avaliação de mercado, técnica e financeira; e definição do conceito do produto a partir da ideia, com o desenvolvimento, teste e avaliação do conceito para obter ou não a aprovação e seguir para o desenvolvimento do produto. 
As entrevistas em profundidade foram realizadas de forma semiestruturada, com a utilização do instrumento de pesquisa (disponibilizado no Apêndice deste trabalho), que serviu como guia para a interação com os entrevistados. Esse procedimento possibilitou que cada entrevistado se aprofundasse nas áreas em que tinha maior conhecimento e que o entrevistador agregasse perguntas adicionais às estabelecidas. $\mathrm{O}$ uso de entrevistas semiestruturadas é uma abordagem que, segundo Hair (2005, p. 167), “(...) pode resultar no surgimento de informações inesperadas e esclarecedoras melhorando as descobertas". Gil (1987, p. 133) indica, ainda, que as entrevistas são a principal fonte de informação para um estudo de caso, e salienta que a entrevista em profundidade é aplicável a um estudo de caso porque permite ao entrevistado não só descrever os fatos, mas opinar sobre eles, bem como sugerir materiais e outros contatos, o que colabora para enriquecer os resultados desse tipo de estudo. Sobre a entrevista em profundidade, Hair (2005, p. 167) explica que se trata de uma entrevista individual que permite um aprofundamento sobre as razões que suportam a resposta apresentada pelo entrevistado, revelando os fatores que influenciam determinados comportamentos. Hair também destaca a necessidade de escolher os entrevistados quanto ao seu grau de envolvimento e conhecimento do caso pesquisado, como forma de focar no descobrimento de situações relevantes à pesquisa realizada.

Os entrevistados que compuseram a amostra intencional não probabilística foram selecionados a partir de seu cargo na organização e envolvimento com os processos de inovação que já foram realizados. A seleção dos candidatos também levou em consideração a escolha de representantes dos dois países (Brasil e México) com maior representatividade nos negócios da empresa na América Latina, sendo a representatividade medida em termos de volume de vendas em dólar.

Antecipando possíveis desistências, foi convidado um número maior de participantes que o planejado. A proposta de amostra original foi planejada com nove entrevistas, mas foram convidadas onze pessoas e todas elas aceitaram o convite, ficando a amostra final com um total de onze entrevistas realizadas, conforme apresentado no Quadro 1.

O processo foi realizado por meio de convite pessoal e, uma vez recebido o aceite, foram agendadas reuniões de uma hora com cada participante para a realização das entrevistas. Todas as entrevistas foram conduzidas pessoalmente e virtualmente, utilizando ferramentas de 
conferência à distância (i.e. Skype) quando os participantes estavam impossibilitados de estar presencialmente.

Quadro 1 - Distribuição Amostral dos Entrevistados

\begin{tabular}{|c|c|c|c|}
\hline \multirow{2}{*}{ País } & \multirow{2}{*}{ Cargo } & \multicolumn{2}{|c|}{ Número de Entrevistados } \\
\cline { 2 - 4 } & & Planejados & Realizados \\
\hline \multirow{3}{*}{ Brasil } & Executivo Senior & 2 & 3 \\
\cline { 2 - 4 } & Gerente Senior & 2 & 3 \\
\cline { 2 - 4 } & Engenheiros e Cientistas & 2 & 1 \\
\hline \multirow{3}{*}{ México } & Executivo Senior & 1 & 1 \\
\cline { 2 - 4 } & Gerente Senior & 1 & 1 \\
\cline { 2 - 4 } & Engenheiros e Cientistas & 1 & 11 \\
\hline
\end{tabular}

Fonte: Elaborado pela autora.

Todas as entrevistas foram gravadas com o aceite dos entrevistados e, por questões éticas, a identidade de todos foi mantida em sigilo, preservando o anonimato dos participantes. As entrevistas foram transcritas e informações consideradas confidenciais foram omitidas das transcrições. Três das onze entrevistas foram conduzidas em espanhol, e suas transcrições foram mantidas em seu idioma original.

\section{Quadro 2 - Perfil dos Entrevistados}

\begin{tabular}{|c|c|c|c|c|c|c|c|c|c|}
\hline Identificação & Cargo & Páis & $\begin{array}{c}\text { Anos de } \\
\text { Empresa }\end{array}$ & $\begin{array}{l}\text { Participou de } \\
\text { ciclos do IME? }\end{array}$ & $\begin{array}{c}\text { Contribui com } \\
\text { ideias IME? }\end{array}$ & $\begin{array}{c}\text { Ideia } \\
\text { escolhida? }\end{array}$ & \begin{tabular}{|c|} 
Liderou \\
Projeto \\
Selecionado? \\
\end{tabular} & $\begin{array}{c}\text { Membro de time } \\
\text { de projeto } \\
\text { selecionado? }\end{array}$ & $\begin{array}{r}\text { Liderou o } \\
\text { processo de } \\
\text { IME? }\end{array}$ \\
\hline Entrevistado 1 & Executivo & Brasil & 30 & sim & $\operatorname{sim}$ & 1 & não & não & não \\
\hline Entrevistado 2 & Executivo & Brasil & 20 & $\operatorname{sim}$ & sim & 1 & não & não & $\operatorname{sim}$ \\
\hline Entrevistado 3 & Executivo & Brasil & 30 & sim & sim & 1 & não & não & não \\
\hline Entrevistado 4 & Gerente & Brasil & 15 & não & não & 0 & não & não & não \\
\hline Entrevistado 5 & Gerente & Brasil & 19 & sim & sim & 1 & $\operatorname{sim}$ & não & não \\
\hline Entrevistado 6 & Gerente & Brasil & 10 & $\operatorname{sim}$ & sim & 0 & não & sim & não \\
\hline Entrevistado 7 & Engenheiro & Brasil & 11 & $\operatorname{sim}$ & sim & 0 & $\operatorname{sim}$ & sim & não \\
\hline Entrevistado 8 & Engenheiro & Brasil & 7 & $\operatorname{sim}$ & sim & 0 & não & $\operatorname{sim}$ & não \\
\hline Entrevistado 9 & Executivo & México & 7 & $\operatorname{sim}$ & sim & 1 & não & $\operatorname{sim}$ & sim \\
\hline Entrevistado 10 & Gerente & México & 10 & $\operatorname{sim}$ & sim & 0 & não & $\operatorname{sim}$ & não \\
\hline Entrevistado 11 & Engenheiro & México & 13 & sim & sim & 0 & não & $\operatorname{sim}$ & não \\
\hline
\end{tabular}

Fonte: Elaborado pela autora. 
O perfil dos entrevistados foi compilado e está apresentado no Quadro 2. Da amostra de onze entrevistados selecionados, somente uma pessoa que tem o cargo de gerente não havia participado de nenhuma etapa do processo EMGI, mas sua contribuição foi mantida por apresentar aspectos de outros processos de inovação existentes na empresa DuPont.

Dois executivos entrevistados foram líderes do processo EMGI, envolvidos no planejamento e execução do processo, incluindo logística, seleção de temas, seleção dos métodos e técnicas aplicados, participantes envolvidos, rituais de reuniões de acompanhamento e gates até o encerramento do ciclo. Um desses entrevistados foi responsável pela exportação do processo EMGI para países na Ásia.

Seis entrevistados contribuíram, além da etapa de geração de ideias, liderando ou atuando como um membro da equipe das ideias selecionadas, para desenvolvê-las e submetê-las aos estágios seguintes.

Quanto ao número de ideias fornecidas pelos entrevistados e escolhidas para serem desenvolvidas, cinco entrevistados contribuíram com ideias que foram selecionadas e um entrevistado indicou que essa era uma pergunta difícil de responder em função de o método de geração de ideias ser colaborativo. Como os diferentes métodos aplicados ao longo dos anos se baseavam no compartilhamento e melhoria das ideias através da interação do grupo, ao final todas as pessoas do grupo que trabalharam na ideia selecionada poderiam se sentir como o gerador da ideia:

Si tu le preguntas a la gente que participaba, todos te van a decir que de alguna forma la idea final que pasó era de ellos. Todos. Y en parte tienen razón. Porque yo creo que nunca una idea tal cuál como fue expressada en la primera ocasión por uma persona iba avanzado. Y esa es la belleza del proceso. La idea que llega al final no es la idea de una sola persona, es la inteligencia de $10,15,20$ personas que trabajan durante el proceso y va evolucionando esa idea, se va mejorando, entonces la respuesta corta a tu pregunta es si $i^{8}$ [Entrevistado 9].

A análise dos dados coletados nas onze entrevistas foi executada usando os métodos de análise de conteúdo, considerando as categorias que permitissem responder ao problema de pesquisa.

\footnotetext{
${ }^{8}$ Tradução livre da autora: "Se perguntar às pessoas que participavam, todos vão dizer que de alguma forma a ideia final era deles. Todos. E em parte eles têm razão. Porque, eu creio, que nunca uma ideia, tal qual foi apresentada na primeira vez por uma pessoa, tenha avançado. E essa é a beleza do processo. A ideia que chega ao final não é a ideia de uma única pessoa, é a inteligência de 10, 15, 20 pessoas que trabalham durante o processo e desenvolvem e melhoram essa ideia inicial, então a resposta a sua pergunta é sim”.
} 
"A análise de conteúdo aparece como um conjunto de técnicas de análise das comunicações, que utiliza procedimentos sistemáticos e objetivos de descrição do conteúdo das mensagens" (BARDIN, 1977, p. 38). Segundo Bardin (1977), esse conjunto de técnicas permite a análise da mensagem explícita e implícita do entrevistado, permitindo que o pesquisador explore o conteúdo oral, e por meio da confirmação ou da inferência verifique suas hipóteses. Moraes (1999) ressalta que o método auxilia o pesquisador a interpretar e compreender em profundidade os fenômenos estudados, e para isto o pesquisador não faz uma leitura normal do conteúdo, mas uma leitura interpretativa dos dados coletados.

Para a execução da análise de conteúdo foi definida uma estrutura de análise, a partir das categorias apresentadas na Figura 11. O eixo norteador da análise foi o processo de inovação EMGI da empresa DuPont. Dentro desse tema foram especificadas as seguintes categorias: geração e pré-seleção de ideias, plano de negócio de alto nível e plano de desenvolvimento estratégico. Dentro da categoria de geração e pré-seleção de ideias, se definiram como unidades de análise o método de brainstorming e os participantes.

Figura 11 - Estrutura para análise de conteúdo

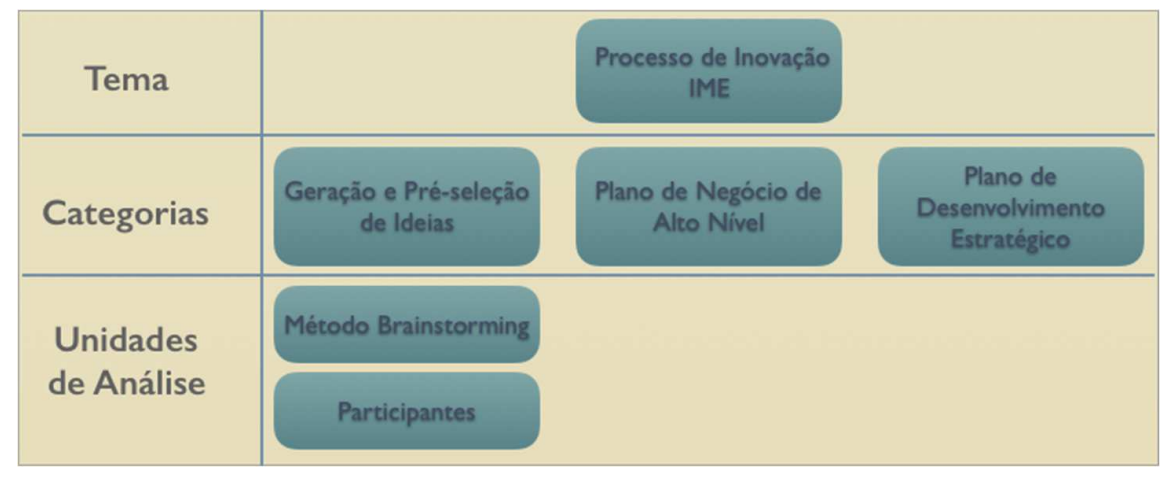

Fonte: Elaborado pela autora.

As categorias e unidades de análise foram definidas somente como forma de guiar a análise, uma vez que este estudo é qualitativo. Por exemplo, na unidade de análise método de brainstorming, investigou-se o impacto do método aplicado, e a análise limitou-se à geração de ideias inovadoras no processo EMGI, por se tratar de uma geração de ideias que requer conhecimento de múltiplas áreas de negócio. 
$\mathrm{Na}$ outra unidade de análise - participantes -, se analisou se a repetição dos integrantes na geração de ideias afetou a geração de ideias inovadoras e/ou se a participação restrita a funcionários limitou o conhecimento do grupo na geração de ideias.

Para analisar os dados, as respostas dos entrevistados foram agrupadas por categoria e a participação de cada entrevistado foi analisada e comparada com as demais respostas, permitindo contrapor o resultado das entrevistas com a teoria estudada. 


\section{ANÁLISE DOS DADOS COLETADOS}

A empresa DuPont é reconhecida mundialmente pela inovação e atingiu esse reconhecimento pela aplicação de diversos processos para gerar inovação em diferentes níveis da organização, conforme aponta o entrevistado 1: "Nós temos vários processos [de inovação] ${ }^{9}$, e alguns são processos locais. Por exemplo, a fábrica tem o seu processo de geração de ideias para melhorar a produtividade”. Há também o processo central de inovação conduzido na Estação Experimental localizada nos Estados Unidos: "A empresa DuPont já tem um processo de inovação global [conduzido] no centro de pesquisa central, muito focado dentro de um negócio" [Entrevistado 1]. O mesmo entrevistado destaca, ainda, o processo de inovação executado nos Centros de Inovação, que promove a interação entre um cliente e uma unidade de negócio "trazemos um cliente [ao Centro de Inovação], apresentamos o portfólio de soluções da empresa, o cliente apresenta o seu escopo de atuação e juntos, em um processo de geração de ideias, buscam-se sinergias em que os líderes de ambas as empresas veem valor”. Outro entrevistado destaca que "existem diversos Centros de Inovação ao redor do mundo, e estes centros estão interligados e possuem um processo próprio de inovação. Por meio dos Centro de Inovação se tem a conexão com toda a rede de pesquisadores da empresa. Baseada na necessidade do cliente convidado, pode-se envolver outras unidades de negócios para colaborar" [Entrevistado 5].

Um entrevistado cita o uso do método Kaizen e os comitês por segmento de mercado que também são utilizados para gerar inovação de processo e produto. Quanto ao uso do método Kaizen, esse mesmo respondente ressalta que este "leva à imersão em uma oportunidade ou problema, com a participação de representantes de todos os membros de cada etapa do processo analisado, inclusive clientes. Assim [com a aplicação do método Kaizen] criaram-se novos processos e partes de um novo produto" [Entrevistado 4].

Já os comitês de segmento de mercado têm como responsabilidade trazer a perspectiva dos clientes, ou seja, as oportunidades ou problemas que a unidade de negócio pode explorar. Os

\footnotetext{
${ }^{9}$ Para esclarecimento das falas dos entrevistados, foram adicionados complementos entre colchetes ao longo da análise.
} 
comitês de segmento de mercado também auxiliam no entendimento do mercado, inclusive na melhor linguagem para se relacionar com clientes do mercado em questão.

O processo EMGI é mais um processo de inovação aplicado pela empresa DuPont e este diferencia-se dos anteriores por apresentar como característica a colaboração entre múltiplas unidades de negócios para buscar oportunidades e soluções para problemas dos países emergentes da América Latina. O tipo de oportunidade identificada poderia ser uma inovação incremental, como também uma inovação radical: "quando se faz um processo EMGI corporativo para a região, buscam-se ideias inovadoras, breaktrough. Não é o objetivo resolver problemas pontuais de um negócio" [Entrevistado 2]. Os processos estabelecidos para o EMGI eram bem específicos para esse processo, sendo ele em si uma inovação.

Quanto aos processos de inovação da empresa DuPont, um entrevistado destaca que:

Todos esses processos funcionam, mas eles precisam sempre ser renovados porque [as pessoas envolvidas podem perder a motivação se suas ideias não passam para a execução] e os processos podem morrer. Os processos de inovação precisam contar com inovação para criar novos processos. [Esses processos] têm que ser renovados para continuar estimulando as pessoas, ou há a necessidade de se ter uma renovação de pessoas muito grande dentro da empresa, o que não é o caso na empresa DuPont [Entrevistado 1].

A mesma percepção de que os processos têm que ser renovados é compartilhado por outro entrevistado: "o processo tem que considerar se ocorreram vícios, se as pessoas se adaptaram e se estão usando o processo [não alinhado com as suas premissas]” [Entrevistado 3].

Constata-se que uma empresa inovadora pode buscar múltiplos processos de inovação para buscar oportunidades de diferentes formas para manter suas fontes de inovação, e todas estas são intencionalmente estabelecidas, estruturadas e disciplinadas (UTTERBACK, 1970; COOPER, 1988; DRUCKER, 2002; COOPER, 2001, 2008). A forma de gerenciamento da inovação pode variar conforme o tipo de inovação (O'REILLY III; TUSHMAN, 2004; BESSANT et al.; 2005), pois há indícios neste estudo de que alguns dos processos citados tinham por objetivo diferentes tipos de inovação. 


\subsection{O PROCESSO EMGI}

O processo Emerging Markets Growth Initiatives (EMGI), em si, foi uma inovação de processo, conforme definição da OECD (2005). O processo EMGI foi desenhado, implantado e executado pelos membros da organização da América Latina com o intuito de combinar esforços entre as diferentes unidades de negócios para gerar inovação de produto e atender às necessidades dos mercados locais.

Diferentemente dos processos citados anteriormente, que envolviam apenas uma unidade de negócio e/ou eram direcionados para a necessidade específica de um cliente, o foco do processo EMGI previa a colaboração entre diferentes unidades de negócios, visando buscar soluções para mercados emergentes. "O objetivo do processo EMGI era identificar alguma forma de sinergia entre os negócios e gerar ideias maiores do que se geraria se fosse um só negócio” [Entrevistado 1]. Outro entrevistado descreve os objetivos do processo EMGI como:

[...] lo que queríamos era algo que fuera multi business y que fuera sustancialmente grande y que justo en el negocio estuvieran por interese directo en resolverlo, lo que no pudieran resolver en su propio negocio. Buscábamos fomentar proyectos regionales, multinegocio, que nos pudieran ayudar a encontrar oportunidades que un solo negocio no podría resolver ${ }^{10}$ [Entrevistado 9].

Um entrevistado destaca que a forma de avaliar um mercado ou uma indústria e identificar as soluções para os seus problemas é o caminho correto da inovação: “[Com o processo EMGI] olha-se a indústria e qual o caminho [que essa indústria] está seguindo, as necessidades dos seus consumidores e identificam-se que produtos ou tecnologia podem-se oferecer que se encaixem nessas necessidades" [Entrevistado 3]. Outro entrevistado cita a importância de se dar acesso à tecnologia de primeiro mundo aos países emergentes:

[El proceso] estaba enfocado en traducir una necesidad de una base de una economia que probablemente no tenía acesso a tecnología. La tecnología que fabrica a empresa DuPont está siempre enfocada a países industrializados. Entonces el hecho que tuviera esa característica, una modificación tecnológica

\footnotetext{
${ }^{10}$ Tradução livre da autora: “[...] o que queríamos era algo que fosse multinegócios e que fosse substancialmente grande e que os negócios tivessem interesse direto em resolver algo, que não poderiam resolver sozinhos. Buscávamos fomentar projetos regionais, multinegócios, que nos pudessem ajudar a encontrar oportunidades que um só negócio não poderia resolver".
} 
o un desarrollo tecnológico, pero enfocado en la base de la pirámide era fabuloso ${ }^{11}$ [Entrevistado 11].

Porter e Kramer (2011) destacam que há necessidades específicas em países emergentes, e que as empresas globais precisam se atentar para a importância da inovação em produtos ou processos para esses mercados, criando soluções específicas ou redesenhando soluções existentes. Essa necessidade apontada por Porter e Kramer (2011) é confirmada pelos exemplos apresentados:

Os dois processos [global e EMGI] estão corretos, ambos agregam muito valor. Por exemplo, o produto de proteção contra assaltos [gerado a partir do processo EMGI] jamais surgiria como projeto global porque é [uma solução para] um problema específico do Brasil e outros países em desenvolvimento. Outro exemplo é o maior sucesso lançado no mercado de agricultura local. Originalmente o produto foi desenvolvido pelo centro de pesquisa global para uma cultura e localmente era necessário para outra cultura. Houve a necessidade de muita negociação para obter-se aprovação. Dentro dos processos globais há a dificuldade para adaptar os produtos globais às necessidades locais, porque há a necessidade de se fazerem escolhas. Há desafios que se encontram somente no Brasil, como o pré-sal, então a tecnologia tem que ser desenvolvida aqui, em nenhum outro lugar do mundo vai se ter essa experiência [Entrevistado 1].

Outros entrevistados [3 e 5] confirmam a percepção de que o maior valor do processo EMGI era possibilitar à região da América Latina ter uma maior independência para analisar as oportunidades e investir em dois ou três projetos por ciclo baseados em critérios específicos para o processo, com o foco no desenvolvimento de soluções para atender às necessidades de clientes da região. Mais um entrevistado crê que "porque a empresa já conhecia e se sentia bem com o processo de inovação global, isso gerou uma dificuldade em aceitar o processo regional” [Entrevistado 1].

O processo EMGI era um processo disciplinado, alinhado com os estudos de Drucker (2002) que apontam que inovações de sucesso surgem de processos de inovação disciplinados, e contava com apoio da liderança da América Latina, considerado como um fator crítico por diversos estudiosos (BACON et al., 1994; KHURANA; ROSENTHAL, 1998; KIM; WILEMON, 2002; GASSMANN; SCHWEITZER, 2014; KOEN; BERTELS; KLEINSCHMIDT, 2014a) para aumentar a probabilidade de sucesso do processo de inovação.

\footnotetext{
11 Tradução livre da autora: "[O processo] estava focado em traduzir a necessidade de uma economia que, provavelmente, não teria acesso à tecnologia. A tecnologia que a empresa DuPont fabrica está sempre direcionada a países industrializados. Dessa forma, ter a característica de promover uma mudança tecnológica ou um desenvolvimento tecnológico focado à base da pirâmide é fabuloso".
} 
Primeiro tinha-se o suporte da presidência, a alta liderança [estar participando] era muito importante. O processo era muito consistente embasado em metodologias, e os participantes tinham que confiar no processo. Eu vejo, ainda hoje, que muitas empresas não têm [um processo de inovação estruturado]. Acham que inovação é só uma ideia brilhante. [A ideia] é essencial, mas se você não tiver o processo, as ideias se perdem. Vira só uma grande ideia” [Entrevistado 6].

Entretanto, algumas das premissas estabelecidas para o processo podiam restringir o pensamento criativo. Um entrevistado cita a restrição a projetos com mais de doze meses de execução como um inibidor. "O cliente tinha um problema enorme com subprodutos da manufatura, tínhamos ideias boas de como resolvê-lo, mas estávamos limitados pelos próprios recursos locais e pelo tempo disponível para desenvolver e comercializar uma solução [dentro do processo EMGI]" [Entrevistado 3]. Outro entrevistado concorda que o tempo de doze meses eliminava do processo projetos muito inovadores:

Inovação não traz frutos imediatamente. É muito difícil você ter um projeto que, em um ano, traga resultados. É uma construção. Inovar requer bravura, porque tem de investir um tempo para aquilo virar uma realidade. Quantas ideias demoram cinco, seis anos para começar a gerar resultados positivos? [Entrevistado 6].

Os projetos que não eram selecionados pelo processo EMGI ou que após serem selecionados ultrapassavam o período de doze meses, tinham a opção de continuar, e o investimento para realizá-lo deveria ser das unidades de negócios envolvidas, e não mais do fundo corporativo:

O primeiro ano é financiado pelo processo EMGI e [a partir do] segundo ano tem que ir para o negócio. Há projetos muito bons de maturação longa, e muitos projetos não seguiram [dentro do processo EMGI] por causa disso. [Quando o projeto já estava sendo executado dentro do processo EMGI] teve que tomar a decisão entre short e long [term] e [para essa decisão] deve se considerar o momento da empresa [Entrevistado 1].

Durante o período de execução do processo EMGI ocorreram casos em que o projeto ultrapassou o período de doze meses e a unidade de negócio deu continuidade ao projeto, como no exemplo relatado por um dos entrevistados:

Foi dada a continuidade ao projeto, já que no planejamento se a tecnologia funcionasse (e estava funcionando), estimava-se que em cinco anos já poderíamos ter um produto comercial. Na verdade está mais próximo de dez anos. O projeto foi cancelado. Foi [uma decisão] difícil. Há sempre o questionamento: "Será que em mais cinco anos não teríamos um negócio fantástico?" [Entrevistado 1].

O requisito de ter ideias nas quais a solução devesse incluir pelo menos duas unidades de negócio também foi considerado por alguns entrevistados como uma dificuldade do processo. 
"Se a ideia beneficiava em 100\% somente um negócio, era eliminada do EMGI, porque o que se estava buscando era um cross-fertilization, um trabalho de [pelo menos] dois negócios" [Entrevistado 1]. Esse respondente também indica que apareciam casos de ideias que eram de um negócio só. Curiosamente, esses projetos já vinham descritos em grande nível de detalhe e, na verdade, o negócio estava procurando o investimento, mas esses projetos não eram selecionados.

Outro entrevistado também cita a colaboração de unidades de negócios como uma dificuldade: "É uma boa iniciativa, mas é difícil de implementar em uma empresa [como a DuPont], cujos negócios trabalham muito separados. Porque fica o dilema de a qual projeto dar prioridade, o do negócio ou do processo EMGI” [Entrevistado 3].

Nota-se que não há flexibilização no processo em relação às suas premissas e essa rigidez pode ser apontada como um possível inibidor do processo. Algumas dessas oportunidades, como uma ideia de um único negócio, poderiam buscar um dos outros processos de inovação citados como alternativas para desenvolver a ideia. Ser muito flexível quanto às premissas pode desconfigurar as características do processo EMGI. Khurana e Rosenthal (1997) concordam que existe a necessidade de um processo formal, mas indicam que o processo precisa ser flexível.

Em contrapartida, um entrevistado acredita que o processo EMGI abriu um canal formal para os negócios colaborarem, e cita um exemplo em que pessoalmente esteve envolvido:

Uma unidade de negócio me procurou uma vez para ajudá-los em como agregar um produto da minha unidade de negócio em um dos seus produtos. Esse projeto eles não conseguiriam fazer sozinhos [por causa do conhecimento da tecnologia], eu participei como voluntário. [Pelo processo EMGI] você tem a força da metodologia. Se ficasse com um modelo só, se perdem [oportunidades] [Entrevistado 7].

O uso do triple bottom line como critério de seleção de projetos é considerado bom para o processo. Um dos entrevistados ressalta que era fácil avaliar: "ou o projeto tem um impacto ou ele não tem" [Entrevistado 3]. Ao mesmo tempo, esse entrevistado indica que não tinha conhecimento do porquê de esse ter sido um dos critérios definidos para a seleção e questiona se era o melhor critério para a seleção de projetos de inovação na empresa DuPont. 
Apesar de não ser um critério explícito, outro entrevistado salienta que projetos que tinham clientes identificados, no momento da defesa nos gates, possuíam mais chances de seguir para as próximas etapas: "Se havia cinco projetos [sendo avaliados no gate] e só dois iriam ser aprovados... E todos [os projetos] eram interessantes, mas dois já tinham clientes levantando a mão, falando que queriam... Com certeza esses [projetos] levavam vantagem na hora do julgamento" [Entrevistado 5].

Os entrevistados apontam como benefício do processo EMGI a oportunidade de os participantes ampliarem o conhecimento sobre as competências existentes na empresa, "[o processo] estimulava o cross-fertilization" [Entrevistado 5].

Alguns entrevistados [1 e 5] também distinguem como benefício adicional a oportunidade de conhecer os talentos da empresa. Um entrevistado explica que "uma vez que se tinha toda a empresa representada no processo de geração de ideias, tornava-se também uma oportunidade de conhecer talentos" [Entrevistado 5]. Outro entrevistado também destaca a visibilidade dos talentos da empresa que o processo EMGI proporciona:

É um projeto que começou com o objetivo de gerar ideias de crescimento, mas com um processo muito interessante que envolvia vários níveis da organização e com a interação muito mais próxima dentro do ambiente de trabalho, [se] comparado com eventos internos [que executamos para engajar as pessoas]. Colocam-se as pessoas para trabalhar nos projetos, se expor e dar visibilidade [dos talentos] para toda a liderança da América Latina [Entrevistado 1].

Um entrevistado destaca o efeito colateral benéfico mais importante como sendo "a oportunidade de envolver pessoas de diferentes unidades de negócio e diferentes funções em um trabalho em comum, o que ajudou a aglutinar as pessoas na região que chamamos de América Latina, oportunidade que não existiria [sem esse processo]" [Entrevistado 1]. O benefício de trabalhar unido, como uma única região, também é compartilhado pelo entrevistado 9.

Outro entrevistado agrega como benefício entender as necessidades de todos os países que compõem a região: "la colaboración también era romper barreras de países. Te permitía conocer 
cuales eran las principales necesidades de la región, no sólo los países más grandes, sino conhecer el resto de la región"12 [Entrevistado 10].

Outro benefício apontado pelo entrevistado 2 foi o aprendizado de processos, ferramentas, técnicas e métodos que são aplicados até hoje dentro das unidades de negócio. O entrevistado 3 concorda que participar do processo era um bom aprendizado. Outro entrevistado o descreve em detalhes:

[...] todos teníamos claro por lo menos un modelo, una forma, un método exitoso para plantear un business case. Para desarrollar un plan, para hacer un plan estratégico, para hacer la generación de ideas, para desarrollar un value proposition, plan de pricing. El simple participar del proceso era en sí mismo un proceso educativo ${ }^{13}$ [Entrevistado 9].

Finalmente, o entrevistado 5 destaca a oportunidade de se tornar um dos líderes de projeto selecionado. A importância de ser escolhido era ter a visibilidade de liderar um projeto selecionado entre mais de 200 ideias. E outro entrevistado explica que "muitas pessoas se conheceram melhor [participando do processo EMGI] e ficaram unidas. Quando há alguma necessidade, busco até hoje a solução de problemas [com colegas que participaram do processo]" [Entrevistado 2].

Os benefícios secundários obtidos pelo processo são apontados por diversos entrevistados. Nota-se que ter um processo específico para a região, criado e executado pela liderança local, promoveu colaboração, troca de conhecimentos e aprendizados entre os participantes, bem como o senso de união da região. Destacam-se esses benefícios como possibilidades de estudos futuros, pois merecem atenção.

\footnotetext{
12 Tradução livre da autora: "a colaboração também era quebrar as barreiras entre países. O processo permitia conhecer quais eram as principais necessidades da região, não somente dos países maiores, mas conhecer todos os países da região."

${ }^{13}$ Tradução livre da autora: "todos tínhamos claro pelo menos um modelo, um padrão, um modelo de sucesso para defender um business case. Para desenvolver um plano, um plano estratégico, para realizar uma geração de ideias, para desenvolver um value proposition, um plano de preço... Participar do processo era um processo educativo em si."
} 


\subsubsection{FRONT END OF INNOVATION}

Cabe retomar que o processo EMGI compreende três fases: a primeira abarca a geração e préseleção de ideias; a segunda inclui o plano de negócio de alto nível; e a última fase trata do plano de desenvolvimento estratégico, como já apresentado na Figura 8, similar aos 3 estágios do FEI propostos por Cooper (1988). Um dos entrevistados ressalta: "o processo tem que contar com um líder experiente que planeje bem o processo. Há a necessidade de definir qual(is) técnica(s) vai(ão) ser aplicada(s), definir os participantes que deverão ser envolvidos no processo e ter um executivo como patrocinador que suporte todo o processo" [Entrevistado 2].

Outro entrevistado destaca como positivo o processo em diferentes fases e gates:

[...] me gustaba que el proceso tenía como sesiones. No nada más era una vez e ya, sino que iba por un proceso donde las ideas botadas, que mejor casaran con tecnología, fit, triple bottom line iban siendo inoculadas y alimentadas y nutridas. Empezaban de 20, llegaban a 12, luego de 12 iban a seis y luego esos seis se desarrollaban. A través de ir pasando por diferentes filtros y de ensamblando diferentes equipos, lo llevaron a su siguiente nivel, permitía que una idea loca pasara de ser loca a ser una idea quizá un poco más pulida y, con suerte, un diamante" ${ }^{, 14}$ [Entrevistado 11].

Nota-se que, alinhado com a teoria de Cooper (1998), o sucesso de processos de inovação é potencializado quando um processo estruturado é estabelecido para todas as suas fases. O processo EMGI é apontado como estruturado em todas as suas etapas, incluindo as sequências de etapas e gates, para que os patrocinadores acompanhem o processo e avaliem a viabilidade do projeto antes de seguir para o próximo estágio, como sugere Cooper $(2001,2008)$. O processo EMGI definido em etapas também permitiu a construção e o refinamento da ideia através das suas diferentes etapas, reduzindo as incertezas (GASSMANN; SCHWEITER, 2014), evitando descartar ideias prematuramente (KIM; WILEMON, 2002), e direcionando as decisões para que modificações na ideia ocorram durante o processo de definição do projeto e não durante o desenvolvimento do produto (GASSMANN; SCHWEITER, 2014; DOLAN, 1993, apud GOLDENBERG; LEHMANN; MAZURSKY, 2001). Era parte do EMGI ir abandonando ideias durante o processo, de forma a não descartar ideias prematuramente e, ao

\footnotetext{
14 Tradução livre da autora: “[...] me agradava que o processo tinha sessões. Não era um evento único, mas um processo onde as ideias geradas que melhor casavam com a tecnologia, fit, triple bottom line iam sendo desenvolvidas e nutridas. Iniciavam com 20 ideias, chegavam a 12, depois das 12 selecionavam 6 e estas 6 eram desenvolvidas. Através da passagem por diferentes filtros e distintas combinações de equipe, levavam-se as ideias ao nível seguinte, permitia-se que uma ideia louca deixasse de ser louca e se tornasse uma ideia polida que poderia se tornar um diamante."
} 
mesmo tempo, tomar a decisão de seguir em frente ou não baseando-se em dados mais refinados ao longo do processo.

No entanto, existe divergência entre pesquisadores a respeito da estruturação das etapas iniciais do processo de inovação, chamado de pré-desenvolvimento ou FEI. Gaubinger e Rabi (2014), por exemplo, destacam a necessidade de achar um consenso entre flexibilidade e criatividade, de um lado, e estrutura e burocracia, do outro, para dar forma ao processo sem inibir a criatividade dos participantes. O processo EMGI foi estruturado desde a sua fase inicial, e considerou como um dos seus componentes gerar um ambiente criativo, como destacado por um entrevistado: "uma mente, para ser criativa, tem que estar fora de seu contexto. Tem que se criar um ambiente propício à criatividade" [Entrevistado 2].

A forma escolhida para estimular a criatividade foi por intermédio de palestras com clientes, consultores, especialistas e futuristas para tirar os participantes do processo do seu dia a dia, no dia anterior à etapa de brainstorming:

[...] é necessário fazer as pessoas se desprenderem de autocrítica e irem para a etapa de geração de ideias despidas de preconceitos e barreiras. Um processo adotado [pelo processo EMGI] era trazer palestrantes para falar em um contexto no qual as ideias iriam ser geradas. Por exemplo, no projeto sobre Jogos Olímpicos, um representante do Comitê Olímpico Internacional fez uma apresentação sobre o tema [Entrevistado 6].

No caso de tema distintivo, outro entrevistado menciona a qualidade do conhecimento do palestrante no tópico a ser apresentado: "tem que conhecer a indústria e apresentar aspectos relevantes relacionados aos problemas enfrentados na indústria [apresentada]" [Entrevistado $3]$.

No que tange à criatividade, um entrevistado destaca que "todas as pessoas têm capacidade criativa, e o ambiente em que se está inserido pode estimular ou não essa criatividade. $\mathrm{O}$ processo EMGI propiciou esse ambiente criativo" [Entrevistado 2]. Brem, Puente-Diaz e Agogué (2016) ressaltam a dimensão do ambiente criativo como um dos fatores que afetam a criatividade. As palestras e workshops executados antes da sessão do brainstorming, tinham como objetivo criar o ambiente criativo descrito por Brem e colaboradores. 
Os entrevistados 2 e 3 sugerem que a etapa para criar um ambiente criativo deveria durar pelo menos dois ou três dias ao invés de meio dia. A imersão dos participantes em um ambiente criativo por mais dias também é mencionada pelo entrevistado 11.

Um participante exemplifica que "ao trazer um especialista no tópico sobre a falta de alimentos no futuro, os participantes conhecedores do know-how da empresa levam essa necessidade junto com seus conhecimentos para as sessões de brainstorming" [Entrevistado 2]. Ele também destaca que, no processo de criação, o mais difícil é identificar o problema que precisa ser resolvido. Ou seja, a forma como o problema é apresentado precisa ajudar os participantes a conectar a necessidade com as competências existentes na empresa, "é mais difícil identificar o problema que se quer resolver, porque, no fundo, uma vez que o problema é detectado, as soluções surgem" [Entrevistado 2]. Outro entrevistado destaca que "a diversidade de equipe e trazer assuntos fora do contexto são coisas que estimulam a criatividade" [Entrevistado 8]. Esse entrevistado enfatiza a participação de clientes em processos de inovação como um fator positivo.

Outro exemplo da importância dos palestrantes é descrito por um entrevistado:

[...] me recuerdo de una vez, trajimos un experto, que era justamente un economista, él se llamaba futurista a sí mismo. Y el hablaba de cuales son los grandes problemas que íbamos vivir en 50 años. Entonces decía: "miren, la tendencia ya sea de población, la tendencia desde el punto de vista de escasez del agua, y desarrollamos un modelo, un modelo para decir cuáles van ser las circunstancias que íbamos estar en 10, 20, 50 años." Tú te puedes imaginar, la gente ahí empezaba a abrir un poquito su perspectiva ${ }^{15}$ [Entrevista 9].

Para o entrevistado 10 a interação com os especialistas trouxe novas informações que permitiram gerar ideias durante a sessão de brainstorming. $\mathrm{O}$ entrevistado 2 ressalta que o conhecimento dos indivíduos nos tópicos a serem discutidos interfere na riqueza das ideias. Ao discutir sobre a necessidade de alimentos no futuro, um desafio mundial que pode afetar milhões de pessoas, ocorreu o estímulo aos participantes de unir o seu conhecimento técnico com a necessidade apresentada para gerar ideias. Constata-se que quanto maior o conhecimento do indivíduo no domínio, maior a capacidade de gerar ideias, como já havia sido identificado por Amabile (1988). Também se confirma, como Koen e colaboradores (2002) identificaram,

\footnotetext{
15 Tradução livre da autora: “[...] me lembro que uma vez trouxemos um especialista, um economista, que se autodenominava futurista. Ele discutia os maiores problemas que iríamos enfrentar em 50 anos. Ele dizia: "olhem, a tendência é de escassez de água, e desenvolvemos um modelo prevendo as circunstâncias em 10, 20 e 50 anos." Pode-se imaginar que a partir daí, as pessoas começavam a abrir um pouco a sua perspectiva”.
} 
que a colaboração de clientes com outras empresas e instituições é uma alternativa de ter outros participantes no processo de geração de ideias.

Há menção de que o processo poderia ser enriquecido pela adoção de outras metodologias, como a discussão sobre tendências de consumo e o futuro da tecnologia, enfatizando que "os participantes com formação em Engenharia naturalmente fazem o processo ser mais racional. O processo de geração de ideia tem que ser intuitivo, há a necessidade de se pensar aonde o mercado está indo" [Entrevistado 6]. Aplicar as outras metodologias citadas pelo entrevistado auxiliaria os participantes a entender melhor o mercado.

Por outro lado, há quem não concorde que o processo instiga a criatividade: "em termos de processo, a empresa DuPont é boa, só que isso atrapalha. Eu creio que na parte de geração de ideias tem que ser um processo mais lúdico" [Entrevistado 8]. Essa afirmação nos remete a Boeddrich (2004) que constatou que há organizações que acreditam que estruturar o processo inicial de inovação coíbe a criatividade dos participantes.

Uma melhoria de processo sugerida é comunicar aos participantes o que ocorreu com os projetos. Ao longo do processo, diferentes pessoas eram envolvidas e muitas delas não tiveram a atualização do que aconteceu com os projetos: "Creo que ahí la parte de comunicación hubiera sido interesante como para cerrar el ciclo [con los participantes]"16 [Entrevistado 10]. Apontase aqui que era alto o número de participantes envolvidos em um ciclo do processo, e esses participantes poderiam estar presentes ao longo de todas as suas etapas do processo, ou especificamente em uma única etapa. Sugere-se, ainda, aprofundar os estudos de como um processo de comunicação pode influir no engajamento dos participantes, principalmente daqueles mais críticos do processo, como forma de estimular a participação em ciclos futuros.

No total, seis ideias foram relatadas pelos entrevistados como produtos de sucesso, originados e comercializados dentro do processo EMGI. Destacam-se que outros produtos tiveram origem no processo EMGI, mas ultrapassaram o prazo de doze meses, e por isso não são contabilizados como casos de sucesso do EMGI.

\footnotetext{
16 Tradução livre da autora: "Creio que teria sido interessante a comunicação para encerrar o ciclo com os participantes."
} 
Quanto à criatividade, não se detectou pelas respostas dos entrevistados que a burocracia ou o formato prejudicassem a criatividade dos participantes. A contribuição do entrevistado 1, no entanto, menciona haver a necessidade de renovar os processos, ou seja, também inovar nos componentes que formam o processo de inovação para manter o interesse dos participantes. Nota-se que no grupo de participantes havia opiniões opostas quanto ao ser criativo. Um executivo especificamente coloca em dúvida que a criatividade seja estimulada em todos os participantes, se ser criativo é uma característica pessoal de alguns indivíduos ou se há a necessidade de fornecer um tempo para que a criatividade aflore. Ford (1990, apud MCADAM; MCCLELLAND, 2002) confirma, da mesma forma, que o pensamento pode ser estimulado nos participantes com a aplicação de técnicas como o brainstorming.

É interessante citar que o processo EMGI foi exportado para países da Ásia. O entrevistado 11 comenta que os líderes envolvidos em exportar o processo compartilharam que diferenças culturais influíram em como o processo era conduzido em outros países. Outro entrevistado indica que houve a necessidade de adaptar o processo à cultura, ao ambiente socioeconômico e à forma de operar em diferentes países. Ele cita que na China houve o seguinte questionamento: "por qué necesitamos hacer tanto esfuerzo para generar una idea que nos de crecimiento, si aquí el crecimiento llega solo" 17 [Entrevistado 9].

Martins e Treblanche (2003) esclarecem que o sucesso da inovação demanda, entre outros fatores, o estabelecimento de mecanismos de reconhecimento e prêmios. Durante as entrevistas não foi mencionado que o processo EMGI estabeleceu processos de reconhecimentos específicos. Um entrevistado menciona que os participantes não recebiam nenhum incentivo específico para participar do processo.

Na sequência apresenta-se a análise sobre o processo de geração de ideias e, em mais detalhes, os resultados sobre esse processo.

\footnotetext{
17 Tradução livre da autora: "Por que necessitamos ter tanto esforço para gerar uma ideia de crescimento, se aqui o crescimento chega sozinho?"
} 


\subsection{GERAÇÃO E PRÉ-SELEÇÃO DE IDEIAS}

No âmbito das ideias, um entrevistado aponta que estas "existem dentro da empresa DuPont, mas há a necessidade de um processo para trazê-las à mesa de discussão e fazer um filtro" [Entrevistado 1]. O comentário do entrevistado 1 nos remete a Boeddrich (2004), que indica a necessidade de haver um processo sistematizado para capturar ideias. Outro entrevistado destaca que "[...] não é por que se tem um processo e participantes que se chega à melhor ideia. É onde as empresas falham. A melhor ideia pode aparecer de fontes inesperadas" [Entrevistado 2]. Em oposição, outro respondente acredita que, conforme a indústria, as ideias podem acabar: "esgotou mesmo a quantidade de ideias para aquela indústria... A não ser que ocorra algo mais fundamental, trabalhe em algo mais profundo para a indústria, [oportunidades] já foram identificadas" [Entrevistado 3].

No processo de geração de ideias, a pré-seleção era composta de várias etapas: a) sessão de brainstorming para gerar ideias; b) agrupamento e classificação dessas ideias; c) seleção da melhor ideia dentro do grupo; d) desenvolvimento de uma proposta de projeto para cada ideia selecionada; e) apresentação da proposta de cada projeto; f) votação e seleção pelo time de liderança das ideias; g) definição do time e do líder para desenvolver cada proposta de projeto.

A geração de ideias pela sessão de brainstorming era, na verdade, a forma encontrada para identificar a forma bruta da solução de um problema (COOPER, 1998; GURTEEN, 1998; BOEDDRICH, 2004; KOEN; BERTELS; KLEINSCHMIDT, 2014b). As etapas posteriores tinham o objetivo de transformar aquela ideia inicial em uma proposta de projeto, por meio de agrupamento, classificação, seleção e desenvolvimento de uma proposta para entrar em um processo de seleção entre outros projetos (KOEN et al., 2002).

O objetivo do processo de geração de ideia do processo EMGI é descrito por um entrevistado como:

En la idea generation lo que queremos hacer es dentro de un tema, dentro de un escupo que se plantea, queremos tratar de ese caso, durante una sesión de brainstorming. Queremos fomentar el mayor número de ideas disparatadas, totalmente relacionadas, o no tan relacionadas, pero, que con la suma de inteligencia de todo el grupo que está participando, salga el mayor número de ideas para después poder elegir de esas ideas, algunas muy acertadas, otras 
más complejas, tener un grupo ya de ideas al final que nos puedan ayudar a decidir el trabajo para definir un proyecto ${ }^{18}$ [Entrevistado 9].

O ponto de partida para a geração de ideias era selecionar os temas que seriam discutidos em cada ciclo. A seleção dos temas era um processo de geração de ideias em si, conduzido por meio de entrevistas com a liderança da empresa, partindo da pergunta, "quais os problemas atuais ou futuros que mais preocupam?". Na sequência, membros da equipe desses líderes eram entrevistados para obter mais detalhes sobre as preocupações e oportunidades em um mercado ou indústria. De posse de todas essas informações, o time de liderança da América Latina (total ou parcial) definia os temas. Uma vez definido o tema: "ahí tratamos de ser enfocados, para asegurarnos que los temas eran relevantes para el negocio y también para asegurar que nos preparábamos y los expertos que traíamos, las personas que convocábamos eran relevantes para los temas a tratar"19 [Entrevistado 9].

Durante os doze anos do processo EMGI foram usadas várias ferramentas para geração de ideias. Segundo o entrevistado 9, utilizou-se o método tradicional de brainstorming e, posteriormente, o Futures Wheel. O entrevistado 2 indicou que testou o método de geração de ideias por intermédio de bases de dados de colaboração. Na opinião do entrevistado, o uso da ferramenta não é o processo ideal para um processo de inovação com o objetivo do EMGI. O entrevistado acredita que a geração de ideias assíncrona é útil para gerar inovações que facilitem o trabalho no negócio, mas para o processo de geração de ideias, que busca a ideia excepcional, não é o ideal. O entrevistado também cita que existe a necessidade do ser humano em se destacar e que o uso de ferramentas virtuais ainda restringe a participação de algumas gerações. $\mathrm{O}$ entrevistado acredita que "a nova geração já não tem a necessidade presencial, eles fazem idea generation por [ferramentas de] messaging" [Entrevistado 2].

Além da geração de ideias por banco de dados, o entrevistado 2 relata que houve um momento em que o processo EMGI estimulou que os participantes fossem à sessão com ideias já definidas. Do ponto de vista do entrevistado 2, a questão é que "o foco das ideias era orientado

\footnotetext{
18 Tradução livre da autora: "Na geração de ideias, o que queremos é dentro de um tema, dentro de um escopo prédefinido, discutir esse tema dentro de uma sessão de brainstorming. O que queremos é fomentar, com a inteligência de todo o grupo que está participando, o maior número de ideias, relacionadas ou não com o tema, para depois poder selecionar, dessas ideias, algumas mais acertadas, outras mais complexas, e ter um grupo de ideias que ao final nos ajudem a decidir o trabalho para, ao final, ter um projeto."

19 Tradução livre da autora: "[...] passamos a ser enfocados, para assegurarmos que os temas eram relevantes para o negócio e também para garantir que nos preparássemos e que os especialistas que trazíamos e as pessoas convidadas eram relevantes para o tema escolhido."
} 
para um único negócio, para resolver uma necessidade específica, [os participantes] não vinham com ideias excepcionais".

O processo EMGI empregou diversas técnicas e métodos (COOPER, 1988; KOEN et al., 2002)

para a etapa de geração de ideias no intuito de identificar a mais propícia para o processo, sendo que o uso de sessões de brainstorming foi o predominante.

O processo de geração de ideias utilizava o método de brainstorming para divergir e depois empregava outros métodos para convergir e sair com propostas de ideias para apresentar para votação. Um entrevistado descreve esse processo de conversão:

Dónde ya de muchas ideas [del brainstorming] queríamos llegar a unas cuantas, que ya estuvieran un poco más aterrizadas y que pudieran ya llevarnos a una posible solución, una posible oportunidad real. [Había equipos] que terminaban con 50,60, 100, 200 ideas distintas... Y con todas esas ideas, nosotros lo que hacíamos era: los poníamos sobre una pared. En desorden, no teníamos quien lo ordenara, simplemente las poníamos todas. Una vez que tenemos todas las ideas, comenzaba, ahí, sí, la sesión de convergencia. En la sesión de convergencia, y también había diferentes métodos, pero el que más usábamos era: pedíamos que la gente, en silencio, fuera tratando de agrupar las ideas en grupos o en clusters que tuvieran algún tipo de relación. No había tema, cada quién las iba agrupando en base a algunas similitudes que la gente veía. Entonces dedicábamos una media hora, una hora. Ya que estaban agrupados le nombrábamos el cluster. E ya íbamos de alguna manera haciendo la convergencia de las ideas. Cuando teníamos esos grupos ya con sus clusters nombrados, ahí el siguiente paso era: asignábamos los diferentes grupos a diferentes personas. Y los grupos tenían que hacer era: tomaban todas las ideas, las documentaban en electrónico y lo que hacían era: elegían de esas ideas dentro de esos temas una o dos que realmente creyeran que pudiera solucionar el problema, o que pudiera capturar la oportunidad que habíamos previamente identificado ${ }^{20}$ [Entrevistado 9].

Um entrevistado descreve que "no processo de agrupamento das ideias, dividiam-se os participantes e cada grupo recebia um conjunto de ideias para estruturá-las em um projeto" [Entrevistado 8]. Durante a seleção das ideias dentro do grupo, para definir qual seria

\footnotetext{
20 Tradução livre da autora: "De muitas ideias geradas durante o brainstorming queríamos chegar a um número de ideias mais factíveis e que podiam nos levar a uma possível solução, uma possibilidade real. Havia equipes que terminavam com 50, 60, 100, 200 ideias diferentes, sem ordem. Não as ordenávamos. Uma vez que todas as ideias estavam listadas, começávamos a etapa de convergência. Nessa sessão, utilizando métodos diferentes, o que mais utilizávamos era: pedíamos às pessoas que, em silêncio, agrupassem as ideias em grupos ou clusters que tivessem algum tipo de relação. Não havia um tema, as pessoas as agrupavam com base nas similaridades que encontravam. Dedicávamos uma meia hora, uma hora, nessa etapa. Uma vez agrupados, nomeávamos o cluster. E, dessa maneira, já estávamos fazendo a convergência de ideias. Após o agrupamento, o passo seguinte era: definir os diferentes clusters para um grupo de pessoas. E os grupos pegavam as ideias do cluster, documentavam-nas eletronicamente, e definam dentro todas as ideias, uma ou duas que realmente acreditavam que poderiam solucionar o problema ou que poderiam capturar a oportunidade identificada previamente."
} 
apresentada para avaliação, o entrevistado 7 apontou que as pessoas deixaram de colaborar para batalharem para sua ideia ser selecionada para o desenvolvimento de uma proposta de projeto.

Quanto à criação da proposta de projeto para submeter a pré-seleção, o entrevistado 3 observou situações em que os participantes do grupo que estavam desenvolvendo a ideia buscavam identificar formas de formatar a ideia para que ela atendesse aos critérios de seleção. $O$ entrevistado 8 diz que a proposta de um tempo de 4 horas para a criação de um projeto para a ideia selecionada pelo grupo foi corrida. Outro entrevistado menciona que não basta somente ter uma ideia para ser bem-sucedido no processo de geração de ideias, "[tem que ter] dados ou argumentos suficientes para convencer o grupo [de trabalho] que é um negócio que vale a pensa explorar mais" [Entrevistado 1].

No momento de apresentar a proposta de projeto para votação, um entrevistado destaca que a paixão pela ideia era um fator importante. Ele destaca que, como líder, ele acreditava ser importante o time estar apaixonado pela ideia, "é bom que o [time de projeto] se apaixone mesmo, dessa forma vai fazer a coisa certa" [Entrevistado 1]. Ele acrescenta que os líderes selecionavam as pessoas que demonstravam essa paixão, "a melhor coisa que tem é você dar para alguém um projeto em que a pessoa realmente acredita, porque vai fazer a diferença. Quando você põe pessoas motivadas e inteligentes para fazer um projeto, você obtém resultados" [Entrevistado 1]. O entrevistado também salienta que "times de projeto que não acreditavam muito na ideia foram descartados, porque não conseguiram defender" [Entrevistado 1]. Um dos respondentes também destaca a influência do apresentador para que uma ideia seja selecionada:

Digamos que la mayoría de las ideas eran interesantes, sin embargo, también influía mucho quién presentaba la idea. As veces quien presentaba era muy buen vendedor, que creía en la necesidad, que tenía conocimiento de la industria, cuando él presentaba el proyecto, se enamoraba, ¿no? Decías: "sí, es perfecto." Y tal vez otros proyectos que también eran interesantes, pero el presentador no era tan extrovertido, tan seguro de sí mismo etc., no tenía mayor impacto, entonces el jurado, los jueces que elegían tal vez no prestaban tanta atención, entonces era importante quién mencionaba y presentaba la idea $^{21}$ [Entrevistado 10].

\footnotetext{
${ }^{21}$ Tradução livre da autora: “A maioria das ideias eram interessantes, mas também influenciava muito quem apresentava a ideia. Às vezes quem apresentava era um excelente vendedor, que acreditava na necessidade, que conhecia a indústria, quando essa pessoa apresentava o projeto as pessoas diziam: "sim, é perfeito". E talvez outros projetos que também eram interessantes, mas o apresentador não era tão extrovertido, tão seguro de si, não tinham tanto impacto, então os jurados que selecionaram talvez não prestassem tanta atenção, então era importante quem apresentava a ideia."
} 
Um entrevistado indica que, na etapa de pré-seleção de ideias, os líderes da América Latina seguiam um grupo de métricas bem definido para selecioná-las, "eram entre 8 e 9 métricas, sempre visando ao triple bottom line, ou seja, [a ideia deveria ter] retorno financeiro, ser no mínimo neutra para o meio ambiente e ter um impacto positivo para a sociedade" [Entrevistado 1]. Essas métricas permitiram reduzir o viés na hora da votação dos projetos. Além do grupo de métricas, o entrevistado destaca que o mais importante era a discussão sobre a pontuação atribuída a cada projeto por todos os líderes. O foco estava principalmente nas discrepâncias de opinião,

[...] por exemplo, para [a métrica sobre] o impacto na sociedade [de um projeto], um líder atribuía 10 [alto impacto positivo], enquanto outros atribuíam [zero], totalmente negativo. As explicações de cada líder ajudavam o grupo a enxergar as diferenças. Então, o mediador [do processo] era muito importante, porque ele observava os extremos. [Uma vez discutidas as diferenças] o grupo tinha chance de mudar o ranking que tinha dado e rever o resultado. Esse processo era extremamente valioso para conhecer o pensamento, o instinto das pessoas do grupo de liderança que votava nos projetos [Entrevistado 1].

O entrevistado 2 indica que escolhia de dez a doze projetos na etapa de pré-seleção, pois sabia que ao longo do processo EMGI algumas ideias seriam abandonadas e de três a quatro seguiriam para desenvolvimento. Quanto à pré-seleção de ideias, um entrevistado sugeriu que o critério de seleção considerasse também ideias nas quais a tecnologia estava prestes a ficar disponível no mercado, e indica que pode ser prematuro eliminar uma ideia porque a empresa ainda não possui a tecnologia:

Às vezes havia uma ideia excelente, mas na hora da pré-seleção ouvia-se: "a ideia é excelente, mas a empresa não tem essa competência." A empresa não tem no momento, mas deve-se perguntar, há uma tendência no mercado? A empresa está nessa tendência? Qual o horizonte da empresa em adquirir esta competência? [Entrevistado 5].

O entrevistado 9 destaca que no processo de screening ou pré-seleção das ideais se utilizava o critério do triple bottom line e a representação gráfica do potencial do projeto no mercado-alvo contra a capacidade da empresa como forma de comparar os projetos e identificar, entre diferentes ideias, quais tinham o maior potencial de serem executadas e de retorno financeiro.

Quanto a gerar ideias dentro do formato definido pelo processo EMGI, um entrevistado contesta que a geração de ideias possa ser realizada em um processo de imersão como foi adotado pelo EMGI:

Não é em dois ou três dias que se analisa a indústria e elabora uma ideia inovadora. Eu acho que o ideal seria, após a análise da indústria, [o grupo sair] 
com algumas potenciais necessidades dessa indústria para refletir. Na minha opinião, os insights não acontecem naqueles dois dias, ele acontece com o tempo... Minha sugestão é não se precipitar em ter a ideia, é ficar com a necessidade na cabeça, pesquisar, em algum momento se vai descobrir algo que vai resolver a necessidade [Entrevistado 3].

Em contraposição, outro entrevistado argumenta que: "esse negócio de inspiração genial não existe se o participante não preparar o seu cérebro para pensar naquele tema... Então há a necessidade de cuidar muito da preparação [antes do brainstorming]" [Entrevistado 7].

Os entrevistados 5, 8 e 10 comentam que alguns participantes, em conhecimento do tema a ser discutido na sessão de brainstorming, chegavam com ideias preparadas, inclusive a apresentação. O entrevistado 3 apontou a mesma situação de participantes que trouxeram ideias prontas, e acredita que o fato de os participantes já irem com ideias pré-definidas prejudicou essa etapa.

Curiosamente detectou-se que dois engenheiros entrevistados tinham ideias opostas em relação a conhecer as premissas do processo. Um entrevistado sentiu dificuldade de contribuir na etapa de brainstorming com ideias que atendessem às premissas do processo EMGI, porque foi informado sobre essas premissas momentos antes do início da etapa do brainstorming: "me preocupou um pouco, porque havia algumas ideias que eram muito alinhadas com a unidade de negócio que eu representava, [mas não atendiam à premissa] porque o direcionamento foi feito na hora" [Entrevistado 7]. Esse entrevistado indica que as ideias geradas somente com sua unidade de negócio posteriormente foram desenvolvidas fora do processo EMGI. Em contrapartida, um entrevistado cita que o processo "era muito direcionado. Após os grupos serem divididos, os pilares da seleção eram informados. A partir do momento que se sabe qual o critério de seleção, eles [os participantes] se policiam para pensar naquilo que vai ser aprovado e creio que [esse direcionamento] acaba eliminando boas possibilidades de inovação no processo de geração de ideias" [Entrevistado 8].

Outro entrevistado destaca que: "se sua ideia já morre dentro do seu grupo [ou seja não é a ideia escolhida para apresentar para votação pelos líderes], a pessoa começa a se perguntar "qual o incentivo de continuar no processo se a minha ideia já foi descartada?" [Entrevistado 7].

Pode-se considerar que, para atender às premissas do processo EMGI, a colaboração entre os participantes para gerar ideias era um pré-requisito, principalmente com participantes de outras 
unidades de negócios. Ter ideias previamente pensadas antes da sessão requer a interação entre esses participantes antes do processo EMGI. Sugere-se para estudos futuros aplicar de forma efetiva ferramentas de colaboração virtual para a solução de problemas complexos que envolvam mais de uma unidade de negócio.

Este estudo foca no uso da técnica do brainstorming, que foi o método predominante durante os anos de execução do processo e com os participantes dessa etapa do processo. Em seguida, inicia-se a descrição em profundidade das duas unidades de análise: método brainstorming e participantes.

\subsubsection{MÉTOdo BRAINSTORMING}

Durante os doze anos do processo EMGI, a etapa de geração de ideias usou diferentes métodos de brainstorming para gerar ideias. Um entrevistado comenta que "no início o processo era bem aberto, os participantes podiam contribuir com ideias de qualquer mercado de atuação da empresa. Em uma segunda etapa se passou a direcionar a mercados pré-definidos [com os participantes tendo informação sobre o mercado durante o processo de geração de ideias]" [Entrevistado 1].

Os entrevistados 2 e 9 relatam que dois métodos de brainstorming foram utilizados: "Não se pode repetir as mesmas técnicas do passado" [Entrevistado 2]. Na primeira técnica cada participante escrevia em um post-it a sua ideia e passava para a pessoa ao lado para que construísse, melhorasse a ideia inicial. A segunda técnica aplicada foi a do Futures Wheel, baseada em um cenário futuro. Esse entrevistado destaca que o uso do método brainstorming é na verdade "uma técnica de coleta de dados, para depois se classificarem as ideias apresentadas" [Entrevistado 2].

Outro entrevistado destaca que ter um processo bem definido, claro, para que todos entendam onde começa e onde termina uma sessão é o mais importante:

Yo creo que lo que es importante es tener un proceso en el cuál todos estamos de acuerdo. Y que realmente nos ayuda a pensar fuera de la caja. Hay muchos procesos, frameworks y metodologías que lo logran. Pero sí es bien importante 
que todos estén muy bien definidos, para entender dónde empieza y dónde termina la sesión ${ }^{22}$ [Entrevistado 9].

O entrevistado 2 destaca que o sucesso da sessão de brainstorming está relacionado com o conhecimento dos participantes convidados, seus engajamentos e o ambiente estabelecido para eles, que permitam a livre participação. Ele acredita que o método brainstorming para gerar ideias em grupo traz mais resultados do que o indivíduo pensando sozinho. O entrevistado 3 concorda com o uso do método brainstorming de forma direcionada para um tema para gerar oportunidades, mas acredita que é parte de um processo no qual os participantes deveriam refletir nas oportunidades e, em uma etapa posterior, voltar com as ideias: "achei muito interessante [a técnica de brainstorming utilizada], porque o processo de geração de ideias, inicialmente, era feito de forma individual. Se escrevia [cada ideia] em um post-it e depois se apresentavam as ideias, que então eram classificadas e agrupadas. [A técnica] permitia, a cada participante, a liberdade de colocar no papel a sua ideia”. O entrevistado 8 descreve que participou em uma sessão utilizando a mesma técnica de brainstorming do entrevistado 6 e destaca que, de todos os processos de geração de ideias, esse era o mais estruturado e que as pessoas se motivavam pelas ideias e se voluntariavam para desenvolvê-las.

O entrevistado 10 concorda que foi positivo utilizar a técnica do brainstorming e que isso auxiliou os participantes a se sentirem seguros quanto ao processo. Ele destaca que o uso da técnica Futures Wheel ajudou os participantes a abrir o pensamento, "pensar fora da caixa" para gerar ideias inovadoras. Importante também salientar que o entrevistado 10 indicou que "os participantes acreditavam no processo", ainda que algumas vezes achassem a técnica repetitiva. Um entrevistado descreve as regras utilizadas durante o processo de brainstorming:

Entonces teníamos varias reglas del juego, era como nuestros basics rules, en la cuál era: no hay ideas tontas, todo se vale. Algunas de las ideas tienen que ser disparatadas, tenemos que decir “¿qué? ¿Realmente eso es una idea?”, para forzarlos, realmente forzarlos a pensar out of the box. Después tratar de ser ordenados y respetuosos, por supuesto, tratar de eliminar nuestros propios paradigmas. Es decir, no permitir cosas como: "oye, ya hemos intentado eso mil veces, vamos a tratar de realmente sacar algo que pueda funcionar", o "vamos a pensar en ideas palpables, no en algo futurista", o "no hay que soñar", todo eso... quitar esos paradigmas ${ }^{23}$ [Entrevistado 9].

\footnotetext{
22 Tradução livre da autora: "Eu acredito que o importante é ter um processo no qual todos estamos de acordo. E que realmente nos ajude a pensar fora da caixa. Há muitos processos, frameworks e metodologias que ajudam. Mas o importante é que todos estejam bem definidos para entender onde começa e onde termina a sessão."

${ }^{23}$ Tradução livre da autora: "Tínhamos diversas regras de jogo, eram como as regras básicas: não há ideias estúpidas, tudo vale. Algumas ideias têm quer ser absurdas, tínhamos que dizer 'o quê', 'isso realmente é uma
} 
A técnica de brainstorming utilizada democratizou o processo, todos tinham o direito de se expressar, apresentar ideias, independentemente do nível hierárquico. Um entrevistado indica essa democratização como o "maior ponto positivo do processo" [Entrevistado 7]. Outro entrevistado indicou, no entanto, que não se sentiu confortável com o processo:

[...] ficamos três ou quatro dias para fazer a geração de ideias, selecionar e escrever uma proposta de projeto. Eu achei muito corrido. Eu não senti que estava aberta para pensar em novas ideias. O processo de geração de ideias tem de ter tempo para fomentar a criatividade. Tem que ter estímulo para sair um pouco do contexto em que vive" [Entrevistado 8].

Esse respondente também sentiu que as regras deveriam ser enfatizadas, principalmente para insistir que "estamos nessa fase [de geração de ideias], todas as ideias são bem-vindas. Não podemos matar nenhuma ideia” [Entrevistado 8].

Quanto ao processo utilizado, um entrevistado destaca que o objetivo era de divergir durante a sessão de brainstorming:

Tratar durante la primera etapa de la sesión de generación de ideas ir a los extremos, realmente push the boundaries. Para tratar de tener todo el panorama que podamos tener. Y esa sesión de generación de ideas, nosotros le llamábamos de diverging. Estamos haciendo una divergencia, desde donde estamos empezando, estamos ampliando el horizonte en más ideas, en más un problema, una oportunidad que ya habíamos identificado y esa es la primera parte. Lo que queremos obtener es el mayor número de ideas, tomando en cuenta el mayor número de posibles impactos, tomando en cuenta las diferentes áreas, diferentes formas como se podría solucionar un problema o capturar una oportunidad. Entonces esa era la primera etapa. Después, durante la segunda etapa, ya que teníamos todas las ideas, empezábamos con la sesión de convergencia ${ }^{24}$ [Entrevistado 9].

Quanto ao volume de ideias, os entrevistados 5 e 6 indicaram que nos processos em que eles participaram surgiram muitas ideias. Os entrevistados 1 e 2 identificam que nos primeiros ciclos do processo EMGI, o volume de ideias foi alto, e houve uma redução nos ciclos posteriores. Uma forma de superar essa redução foi mudar o processo e trazer pessoas externas à

ideia?', para nos forçarmos a pensar fora da caixa. Depois, tratar de ordená-las e, de uma forma respeitosa, tratar de eliminar nossos próprios paradigmas. Não permitir coisas como: 'já tentamos isto mil vezes, vamos tratar de achar algo que realmente pode funcionar', ou 'vamos pensar em ideias factíveis, não em algo futurista', ou 'não podemos sonhar', eliminar todos esses paradigmas."

${ }^{24}$ Tradução livre da autora: "Tratar, durante a primeira etapa da sessão de geração de ideia. de ir aos extremos, passar dos limites. Para permitir ter todo o panorama que podemos ter. E chamávamos essa sessão de geração de ideias de divergir. Estávamos fazendo uma divergência, desde o princípio estávamos ampliando o horizonte de mais ideias, em mais um problema, uma oportunidade que havíamos identificado. O que queremos obter é o maior número de ideias, levando em conta o maior número possível de impacto, as diferentes áreas, as diferentes formas de como se poderia solucionar um problema ou capturar uma oportunidade. Depois, na segunda etapa, após ter todas as ideias, começávamos a sessão de convergência." 
organização para trazer insights do mercado e da indústria, com uma outra perspectiva do futuro para fomentar ideias, por meio de palestras e workshops, conduzidos na noite anterior do início da sessão de brainstorming.

Quanto à repetição de ideias, o entrevistado 6 indica que isso ocorria em grupos em que havia pessoas que trabalhavam juntas ou dentro do mesmo negócio. Um entrevistado reflete que talvez as ideias realmente se esgotem quando se repetem pessoas por diversos anos: "você tem as mesmas pessoas discutindo as mesmas indústrias por cinco anos seguidos, acho que [a repetição] acaba esgotando [as ideias]" [Entrevistado 1]. Ele exemplifica que no "primeiro ano foi um negócio fantástico, difícil até de fazer a seleção, e aí o volume de ideias foi diminuindo". Esse respondente também recorda que, quando começou ocorrer a diminuição do volume de ideias, se criaram processos diferentes, ou seja, foi feito um foco na etapa de geração de ideias em temas específicos e passou-se a "trazer pessoas de notório saber na área [selecionada]" [Entrevistado 1], como forma de ajudar os participantes a conectar as necessidades da indústria com a tecnologia existente na empresa DuPont.

Um entrevistado reforça que "a mistura de pessoas é a chave [do processo]" [Entrevistado 2], seguindo a mesma percepção do entrevistado 1: "nos primeiros dois ciclos gerou-se muito mais ideia do que no terceiro. Porque no terceiro já não misturamos mais pessoas. Sempre era o mesmo grupo, praticamente" [Entrevistado 2]. Ele acredita que isso ocorreu porque "no começo tem-se um monte de ideias borbulhantes [represadas]. Na segunda vez, os participantes esgotaram as ideias. No terceiro, realmente tem de se entrar nas ideias novas" [Entrevistado 2].

O entrevistado 3 também compartilha a percepção de que as ideias foram se esgotando quando se repetiam a indústria ou os mercados. $\mathrm{O}$ entrevistado 5 aponta que algumas ideias retornavam na sessão de brainstorming em ciclos subsequentes, não porque faltava criatividade, mas porque as condições de mercado ou tecnologia tinham mudado. Ou seja, uma ideia que foi descartada em um ano por não ser viável, retornava nos anos seguintes, e nesse momento poderia já ter se tornado viável. No momento em que a ideia se repetia, no processo de préseleção poderiam ocorrer duas coisas: "essa ideia já foi estudada, nada mudou e ela não era selecionada. Ou questionava-se o que mudou, e eventualmente ela poderia ser selecionada" [Entrevistado 5]. Outro entrevistado cita o exemplo do evento descrito pelo entrevistado 5: "eu mesmo liderei um projeto que nós descartamos, porque era uma ideia que já tinha sido gerada, 
e voltou um pouco modificada. Nós pesquisamos, fizemos diversas análises e não deu certo. Então abandona-se a ideia e tenta-se buscar uma coisa nova" [Entrevistado 1].

Outro entrevistado é mais enfático ao afirmar que "muitas ideias voltavam. A unidade de negócio trabalhava um pouco mais na ideia, e na sessão seguinte a trazia um pouco mais madura" [Entrevistado 3]. No ponto de vista desse entrevistado, a situação de retornar a ideias rejeitadas anteriormente coibiu a inovação "porque [quando essa repetição ocorre] acaba não se tendo mais a inovação em si, mas um processo de revisitar ideias para que elas se encaixem nas premissas do processo, para serem selecionadas e obter investimento. Não significa que é ruim, mas eu acho que as premissas do processo levavam um pouco a essa situação" [Entrevistado 3].

Um respondente confirma a possibilidade de repetição de ideias e afirma que se incluíam artifícios no processo para minimizar a repetição de ideias. "Entonces intentábamos que los temas fueran variando año con año. Incluso, tratar de que pasara más de un año. Dos años para volver a tocar un tema en algunos de los negocios. O por lo menos en esa área de negocio. Tambíen se ententaba cambiar los expertos y las personas, com el cambio de temas" 25 [Entrevistado 9].

Um entrevistado sugere que "talvez fosse mais eficiente se os participantes tivessem feito um trabalho prévio, colaborado antes do brainstorming para serem mais eficientes na geração de ideias. Não há como um brainstorming ser eficiente se não houver um estudo anterior [sobre o assunto]" [Entrevistado 7].

O entrevistado 6 menciona que "às vezes, íamos para uma etapa posterior do processo [após a pré-seleção], e se eu tive uma ideia que achei brilhante e não passou no primeiro filtro, ficava me questionando: ‘será que entenderam mesmo minha ideia?’ E a pessoa fica com uma certa fixação em tentar trazer de volta: 'mas e se fizéssemos daquele jeito?'.” O entrevistado 6 indica que não presenciou a repetição de ideias durante os ciclos em que participou. $\mathrm{O}$ entrevistado 8 nota que ideias rejeitadas anteriormente pelo processo EMGI ou por outros processos voltavam a ser apresentadas. Ele sugere aproximar mais as pessoas que estão no mercado para trazer esses

\footnotetext{
25 Tradução livre da autora: "Tentávamos fazer com que os temas fossem variados ano após ano. Inclusive, tratar de que tivesse passado mais de um ano, dois anos para voltar a um tema em alguns negócios, ou pelo menos em uma área de negócio. Também se tentava modificar os especialistas e pessoas com as mudanças de tema."
} 
insights do mercado para dentro da empresa DuPont. Um entrevistado aponta que os participantes se repetiam porque a empresa não é muito grande na região: "a escolha dos participantes era um processo genuíno de buscar quem conhecia sobre o tema a ser abordado, quem estava envolvido no assunto e [esse processo de engajar as pessoas com conhecimento apropriado] é importante" [Entrevistado 3]. Outro entrevistado cita que "a essência [do grupo de participantes] era o grupo de liderança, que sempre participava, e outras pessoas eram convidadas, [mas durante os anos de execução do processo EMGI] ocorreram poucas mudanças no time de liderança. Todos são muito criativos, [mas havia a repetição de pessoas]" [Entrevistado 2]. Ele relata que uma nova forma de estimular a criatividade foi estabelecida quando no processo se colocou o líder de um negócio para liderar o negócio de outro líder: "Dessa forma, se estimulou novamente a criação de ideias inovadoras" [Entrevistado 2].

Quanto à repetição de ideias devido ao sucesso de ideias anteriores, os entrevistados 2 e 3 explicitamente registram que não viram a repetição de ideias por as ideias semelhantes terem sido bem-sucedidas.

Um único entrevistado destaca a questão do idioma utilizado na sessão de brainstorming. Como o evento era regional, o inglês foi selecionado como idioma comum: "o idioma utilizado era o inglês e nem todas as pessoas tinham a capacidade de se comunicar de forma fluente" [Entrevistado 11].

Quanto à novidade das ideias, um respondente assinala que, nos primeiros ciclos do processo EMGI, "todas as ideias que saíam eram fabulosas e novas. Tinha ideias originais, com potencial de execução e aplicabilidade. Acredito que por causa da liberdade que as pessoas tinham de falar independente da hierarquia" [Entrevistado 1].

Avaliando as técnicas de brainstorming utilizadas, conclui-se que nos diferentes tempos do processo de geração de ideias foi utilizada a técnica de brainwriting. Constata-se que nesse processo não se identifica a presença dos motivos que possam prejudicar uma sessão de brainstorming identificados por Diehl e Stroebe (1987). Não foi percebido acomodação, apreensão ou bloqueio dos participantes durante a etapa de geração de ideias. Também não se identificou a pressão subconsciente de conformação com o grupo, citada por Janis (1982, apud GIROTRA; TERWIESCH; ULRICH, 2010). A forma com que o brainstorming foi aplicado permitia que os participantes trabalhassem sozinhos para gerar ideias (escrevendo as ideias em 
post-its) (PAULUS; YANG, 2000). De posse das ideias, o grupo trabalhava em conjunto para melhorá-las (PAULUS; BROWN, 2007) e as discussões entre os membros do grupo para rever, agrupar, aprimorar, compor e agregar as ideias apresentadas permitia a discussão entre diferentes membros do grupo, o que incentivava o processo criativo (GURTEEN, 1998). A interação levava a um nível de discussão, inclusive técnica, que gerou a preocupação de se agregarem clientes nesse processo, uma vez que seria difícil evitar o vazamento de propriedade intelectual nesse processo de discussão.

Uma proposição desta pesquisa era investigar se a técnica utilizada para gerar inovação limita a criação de ideias inovadoras em situações que requerem conhecimento de múltiplas áreas de negócios. Conclui-se, assim, que a técnica de brainstorming utilizada não limitou a geração de ideias inovadoras em situações que requeriam conhecimento de múltiplas áreas de negócios.

Diversos entrevistados apontam que durante a sessão de brainstorming o facilitador tem um papel fundamental. Ele conduz os trabalhos de seu grupo de forma a garantir que o processo seja seguido e os princípios do método sejam respeitados: "era un guardián de la metodología"26 [Entrevistado 10]. De acordo com um entrevistado, é papel do facilitador "colocar as ideias em evidência" [Entrevistado 2], e não deixar nenhuma ideia ser rejeitada. O entrevistado 9 destaca que o facilitador tem que atuar como um fator de equilíbrio no grupo que está conduzindo, porque havia temas mais difíceis, grupos com dinâmicas diferentes e, nos grupos com maior dificuldade, o facilitador ajudava as pessoas a não perderem o rumo.

Os facilitadores eram treinados para serem ativos no processo, "entrava[m] [nas discussões], questionava[m], puxava[m] o time" [Entrevistado 2]. "Era uma pessoa treinada em metodologia, preparada para conduzir o processo e com habilidade de comunicação. Deveria saber dosar, saber quando deixar falar, quando trazer a discussão para o foco, mas sem bloquear. O objetivo não era o controle de tempo e agenda" [Entrevistado 6]. Um entrevistado reportou sensível diferença no desempenho do grupo quando compara diferentes momentos do processo ao longo do tempo: "entre los primeiros y los últimos, yo sí vi una diferencia. O sea, porque en los primeiros, a lo mejor había facilitadores que tenían más experiência manejando el grupo y haciendo preguntas difíciles"27 [Entrevistado 11]. O entrevistado 8 não acredita que o

\footnotetext{
26 Tradução livre da autora: "era um guardião da metodologia."

${ }^{27}$ Tradução livre da autora: "entre as primeiras e as últimas sessões, eu vi uma diferença. Nas primeiras havia facilitadores que tinham mais experiência administrando o grupo e fazendo perguntas difíceis."
} 
facilitador ajudou o processo, ele sentiu que algumas ideias foram descartadas prematuramente durante a etapa de brainstorming por estarem muito fora do contexto. Outro entrevistado destaca a preparação que esses facilitadores tinham que executar antes da sessão de brainstorming:

Las personas que coordinaban, tenían que tener el conocimiento bastante amplio, preparase, documentarse con información actual, actualizada. Como iban trabajar con desde directores hasta vendedores, gente de crédito, gente que tal vez no tenía mucha relación en el día a día, tenían que practicar sus habilidades de liderazgo, como orientase a todo un grupo de diferentes personas, como encamina para que vayan aterrizando las ideas ${ }^{28}$ [Entrevistado $10]$.

A escolha do facilitador para cada grupo respeitava o fato deste não estar no mesmo grupo que seu supervisor, para não colocá-lo em uma posição difícil perante o grupo. Um dos entrevistados [7] reportou que a sessão em que participou o próprio presidente da empresa facilitou o processo e notou que as pessoas não se intimidaram com o fato de tê-lo como facilitador.

Conclui-se que o papel do facilitador no processo foi fundamental para que os princípios do uso do método de brainstorming fossem aplicados e que se evitassem problemas advindos da aplicação dessa técnica, problemas estes identificados por diversos autores. A preparação do facilitador na liderança do grupo e das etapas do processo foi citada como fator crítico para que a etapa fosse bem-sucedida. Brem, Puente-Diaz e Agogué (2016) citam a necessidade de estudos adicionais nesse campo para entender como o facilitador deve atuar para se ter uma liderança criativa.

\subsubsection{PARTiCiPANTES}

Ter um processo de geração de ideias estruturado, que estimule a criatividade e que aplique técnicas para gerar ideias é uma parte do processo. No entanto, segundo um entrevistado, o resultado do processo também "depende de os participantes estarem presentes, dispostos a

\footnotetext{
28 Tradução livre da autora: “As pessoas que coordenavam tinham que ter um conhecimento amplo, preparar-se, documentar-se com informações atuais. Como iam trabalhar com diretores, vendedores, gerentes de crédito, pessoas que tinham muita relação com o dia a dia, tinham que praticar as suas habilidades de liderança, como orientar um grupo diverso, como direcionar para que aterrizassem as ideias."
} 
contribuir no ambiente estabelecido. Primeiro, há a necessidade de trocar as pessoas [ao longo do anos]. Minha impressão é que há a necessidade de trazer pessoas de diferentes disciplinas, inclusive de fora da área de conhecimento do tema que se está trabalhando" [Entrevistado 2]. De acordo com esse entrevistado existe a tendência natural das áreas de negócios em convidarem participantes para sessões de brainstorming que são do próprio negócio, entretanto "se os participantes já estão vivenciando o problema no dia a dia, eles já fizeram o máximo. Existe a necessidade de juntar o conhecimento desses participantes com participantes de outras disciplinas para questionar, fazer essas pessoas refletirem e trazerem novas ideias" [Entrevistado 2].

A diversidade dos participantes foi citada por diversos entrevistados como um fator positivo do processo, confirmando os estudos de King e Anderson (1995, apud MCADAM; MCCLLEAND, 2002). Um entrevistado menciona que a "diversidade traz ideias diferentes, porque cada vivência é diferente" [Entrevistado 2]. Outro entrevistado destaca como importante a "diversidade de pensamento. Havia diversos negócios e funções participando do processo" [Entrevistado 5]. Outro respondente indica: “A diversidade acontecia. Quando íamos fazer [um ciclo do processo EMGI] procurávamos levar as pessoas que tinham relação com o tema selecionado. As pessoas que eu indicava para participar variavam conforme o tema" [Entrevistado 3]. Outro entrevistado compartilha que buscava formar grupos bem diversos: "Otra cosa que hacíamos era: nos aseguramos que los grupos fueran muy diferentes. Que la gente en los diferentes grupos tuvieran background, experiencias, edades, género, diversidad, todo, muy diferente. Para realmente asegurarnos que en esas excepciones íbamos a tener ideas muy dispares"29 [Entrevistado 9]. Um entrevistado salienta que a

[...] diversidade é fundamental para o processo de criação. Empresas como a DuPont são organizadas em silos, há unidades de negócios diferentes trabalhando isoladamente. [Ter um processo] com vários representantes da empresa, de diferentes áreas que pudessem contribuir de outra forma, olhando o negócio sobre outro ponto de vista, é muito positivo [Entrevistado 6].

Outro entrevistado também destaca a formação da equipe com diversidade, "un equipo era ensamblado con personas multifuncionales, unos externos, unos internos y a lo largo de dos, tres dias intentaban a lo major no hacer expert ese grupo, pero cuando menos tensionarlo lo

\footnotetext{
29 Tradução livre da autora: “Outra coisa que fazíamos era: nos assegurávamos que os grupos fossem bem diferentes. Que as pessoas nos diferentes grupos tivessem background, experiências, idades, gênero, diversidade. Tudo bem diferente. Para realmente assegurarmos que, com essa diversidade, teríamos ideias bem diferentes".
} 
suficiente para que pensara en posibilidades. Entonces esta multifuncionalidad a mí me pareció rica" 30 [Entrevistado 11].

A colaboração entre os participantes foi considerada uma fortaleza do processo por um dos entrevistados:

[...] lo punto que yo diría como positivo es que permitía primero una colaboración interna por los diferentes times que se formaban. Había personas de finanzas, había personas de diferentes negocios. Entonces esa integración, esa colaboración de diferentes mentes, de diferentes visiones, hacía que el proceso fuera mucho mejor ${ }^{31}$ [Entrevistado10].

Quanto à seleção dos participantes, buscava-se incluir participantes de marketing, finanças, aplicação de produtos, vendas, membros da organização em processo de desenvolvimento com possibilidade de se tornarem futuros líderes da organização e a liderança da organização da América Latina. O entrevistado 10 destaca que "no todas las personas podían ir, entonces había una cierta sensácion entre los empleados que sí, iban, y los que no. Habia una competencia sana, una competencia buena"32 [Entrevistado10].

Outro entrevistado argumenta que na etapa de brainstorming necessita-se de pessoas técnicas e contesta a inclusão de outras pessoas, como de finanças, futuros líderes, etc.: "A empresa DuPont é uma empresa de ciências, existe a necessidade de ter conhecimento científico. A batalha de ideias pessoais de outras áreas não creio que seria necessária” [Entrevistado 7].

Outro fator considerado para a seleção dos participantes era incluir membros da organização que não acreditavam no processo. Havia pessoas no grupo que não acreditavam nesse tipo de processo e eram também consideradas importantes na formação dos times: "tenía esa voz discordante ahí en el proceso y eso nos obligaba a no solamente ser demasiado optimista"33 [Entrevistado 9].

\footnotetext{
${ }^{30}$ Tradução livre da autora: "uma equipe montada com pessoas de múltiplas funções, algumas internas, outras externas e ao longo de dois e três dias buscava-se, não transformar esse grupo em especialistas, mas criar tensão para que pensassem em possibilidades. Dessa forma, essa multifuncionalidade me pareceu bem enriquecedora."

${ }^{31}$ Tradução livre da autora: "o ponto positivo é que permitia primeiro uma colaboração interna pelos diferentes times que se formavam. Havia pessoas de finanças, havia pessoas de negócios. Essa integração, essa colaboração de diferentes perspectivas, de diferentes visões, fazia com que o processo fosse muito melhor."

32 Tradução livre da autora: "nem todas as pessoas podiam ir, então havia uma certa competição entre os que iam e os que não iam. Havia uma competição saudável, uma competição boa."

33 Tradução livre da autora: "tínhamos a voz da discórdia no processo e isso nos obrigava a não ser somente demasiadamente otimistas."
} 
Constata-se que a diversidade intencionalmente aplicada na seleção dos participantes está alinhada com diversos autores que indicam que a melhoria na qualidade da ideia ocorre quando as organizações adotam a colaboração entre unidades de negócios (HANSEN; BIRKINSHAW, 2007) e times multifuncionais (KOEN et al., 2002).

Um entrevistado sinaliza que "um aspecto a considerar [em relação aos participantes] é que há pessoas que são mais criativas do que outras, e é por dom, ou porque trabalha na área, ou porque gosta do assunto e se dedica mais. Essas pessoas têm a capacidade de juntar conhecimentos para gerar uma ideia" [Entrevistado 3]. Ele também cita a intuição como fator contribuidor para o desempenho do processo:

[...] no processo [de geração de ideias] deve haver gente intuitiva misturada com pessoas com características mais lógicas. Talvez faltava um pouco mais de gente intuitiva, tinham poucas na empresa DuPont, e continua assim porque o processo de [recrutamento e seleção de pessoas] busca pessoas mais lógicas [Entrevistado 9].

Outro entrevistado também aponta a intuição como uma característica que contribui para que os participantes sejam mais criativos. "Há pessoas que são mais perspicazes, que por viverem em diferentes meios, quando estão com o cliente ou próximos ao mercado sentem a solução para uma necessidade. Essas pessoas são intuitivas" [Entrevistado 2]. Um respondente menciona que deve-se considerar a característica de personalidade dos participantes, identificar e misturar participantes introvertidos e extrovertidos e ter regras para engajar ambos os tipos no processo de brainstorming, "[el processo debe] balancear o generar reglas donde introvert e extrovert pueden expresarlo, porque enriquecen todos"34 [Entrevistado 11].

Conclui-se que existe a oportunidade de explorar estudos adicionais em relação às questões dos participantes e dos estilos de aprendizados em Kolb e Kolb (2005) e de como utilizar os diferentes estilos de aprendizado para potencializar os resultados das diferentes etapas do processo de inovação.

Quanto à participação da liderança nos grupos de brainstorming, o entrevistado 2 não acredita que a participação dos líderes de negócios nos grupos de brainstorming tenha constrangido os demais envolvidos a ponto de coibir a sua participação. Ao mesmo tempo afirma que "por

\footnotetext{
34 Tradução livre da autora: "o processo deve ponderar ou gerar regras nas quais introvertidos e extrovertidos possam expressar-se, porque enriquece a todos."
} 
natureza, o líder vai comandar”. Outro entrevistado também não constatou constrangimento dos outros participantes pelo fato de a liderança ter participado do brainstorming: "não percebi a hierarquia limitando [o processo]. Minha percepção é que até os participantes queriam [ter os líderes presentes], todos queriam que saíssem ideias boas e inovadoras, o que não é fácil" [Entrevistado 3]. Entretanto, um entrevistado indica que sentiu que seria avaliado pela liderança durante o processo de geração de ideias e sugere que "o líder tem que entrar em determinados momentos, participar de tudo pode prejudicar o processo" [Entrevistado 6]. O entrevistado 8 sentiu que a presença da liderança intimidou e direcionou o processo. Ele sentiu que o ambiente era como uma reunião de trabalho, não um processo de geração de ideias. A mesma percepção de que a liderança inibia foi compartilhada por outro entrevistado, mas este acredita que isso não limitou o processo: "Creio que, dependendo da composição do grupo, alguns participantes se inibiam. Creio que isso é natural, e que no final o processo funcionava" [Entrevistado 5]. Outros entrevistados [10 e 11] também alegam que algumas pessoas se sentiam inibidas com a presença de líderes, e outro ainda cita que era difícil que alguns dos participantes não se sentissem inibidos na presença dos líderes. Ele afirma que se reduzia essa inibição por intermédio das regras de participação no processo de brainstorming e destaca que o facilitador tinha um papel fundamental em garantir que todos tivessem as mesmas oportunidades de colaborar, conforme a regra definia: "en esa sesión de generación de ideas no hay jerarquía, no es que la idea del director vale más que la del gerente y la del gerente más que la del individuo, no hay jerarquías en ese sentido" 35 [Entrevistado 9].

Um entrevistado destaca que a liderança tinha que estar presente, porque ela empurrava o projeto, impunha disciplina e, após o processo de votação, alocava os recursos para que os projetos aprovados seguissem para a próxima etapa. "O líder de negócio tinha que colocar seus recursos, se não o projeto não seguia. O processo EMGI tinha recursos próprios, mas não eram suficientes [para executar todos os projetos]" [Entrevistado 3].

A participação do time de liderança também é destacada por diversos autores como fator crítico para a execução do processo, além da percepção de que os líderes devem estar capacitados para selecionar e investir nas ideias inovadoras (BACON et al., 1994; KHURANA; ROSENTHAL, 1998; KIM; WILEMON, 2002; GASSMANN; SCHWEITZER, 2014; KOEN; BERTELS;

\footnotetext{
35 Tradução livre da autora: "nessa sessão de geração de ideias não há hierarquia, não existe isso de que a ideia do diretor vale mais que a ideia do gerente, e que a ideia do gerente vale mais que a do indivíduo. Não há hierarquia nesse sentido."
} 
KLEINSCHMIDT, 2014a). No processo EMGI a liderança estava presente em todas as etapas, o que inclusive é apontado por alguns entrevistados como um possível fator inibidor na sessão de brainstorming. A atuação do facilitador nas sessões de brainstorming era crítica para minimizar o efeito inibidor da participação dos líderes nessa etapa.

Após alguns anos de execução do processo EMGI, um entrevistado aponta que "las personas año con año iban, conocían el proceso, pero se pusieron un poco cansadas. Porque era año con año las mismas metodologías, tal vez algunas mismas personas..." ${ }^{\text {[6 }}$ [Entrevistado 10].

A participação de agentes externos à organização da empresa DuPont era principalmente concentrada nas etapas de criatividade, através de palestras e workshops. Nessa etapa foi reportado que clientes, consultores e futuristas eram convidados a trazer insights sobre os mercados e indústrias, com uma visão de futuro, para estimular os participantes a conectarem as necessidades atuais e futuras com o conhecimento das competências existentes dentro da empresa DuPont. O envolvimento de agentes externos na etapa de brainstorming era limitado, e poucos exemplos foram apresentados. A principal razão para não incluir agentes externos durante o processo de brainstorming foi proteger a propriedade intelectual da empresa DuPont. Diversos aspectos foram apresentados durante o levantamento de dados, e são descritos a seguir.

A conexão com clientes é apontada como imprescindível por diversos entrevistados para que o processo EMGI identifique soluções que atendam às necessidades dos clientes nos mercados selecionados (GOLDERNBERG; LEHMANN; MAZURSKY, 2001; KIM; WILEMON, 2002). Entretanto, o balanço entre abrir o processo e proteger a propriedade intelectual foi um fator considerado (GASSMANN; ENKEL; CHESBROUGH, 2010). A cada ciclo era definido caso a caso como o engajamento de clientes e outros agentes externos seria feito (GASSMANN; SANDMEIER; WELCHT, 2006).Com excessão da sessão de brainstorming, o processo EMGI permitiu a circulação de ideias externas à organização de diferentes formas, para aumentar as chances de sucesso no processo de geração de ideias (CHESBROUGH, 2003; GASSMANN, 2006).

\footnotetext{
${ }^{36}$ Tradução livre da autora: "as pessoas, ano após ano, iam, conheciam o processo, mas ficavam cansadas. Porque era ano após ano as mesmas metodologias, e talvez as mesmas pessoas..."
} 
Um entrevistado indica que durante a execução do processo EMGI foi trazida "uma quantidade razoável de pessoas externas à organização, principalmente especialistas”. Ele cita como exemplo o ciclo em que o tema era aerospace:

Trouxemos o ex-presidente de uma empresa de aviação para espontaneamente falar quais os maiores problemas dessa indústria, explorando a área técnica, a área de processos, etc. [Esses workshops] nos ajudavam a ter um entendimento melhor do mercado. Trazer clientes também foi fundamental, bem como trazer pessoas que conhecem a área em que estamos pesquisando ideias é extremamente importante e valioso [para guiar a discussão]. O foco era trazer lead-users, os pioneiros, porque senão você vai ouvir os mesmos temas [Entrevistado 1].

Esse entrevistado cita exemplos de cocriação e experimentação que a empresa DuPont executou com clientes e destaca que é muito importante estar envolvido com o mercado, "o time tem que estar do lado do mercado, não pode ficar sentado no escritório. Tem que trazer o que está acontecendo no mercado e gerar alternativas para atendê-lo" [Entrevistado 1]. Outro entrevistado cita que já se incluem clientes na etapa de brainstorming, mas é necessário se ponderar a necessidade de assinar um contrato de confidencialidade: "Tem de ser assinado [um contrato de confidencialidade]. Dependendo do grau de inovação, [se a solução é algo que] a empresa vai querer patentear, entra-se em uma zona cinzenta. É a disputa pela propriedade intelectual" [Entrevistado 2]. Esse entrevistado salienta que diversos consultores contratados participaram da sessão de brainstorming, assinando um contrato de confidencialidade, mas ele entende que a participação de consultores não foi tão enriquecedora: "percebi que [os consultores] se limitavam a dar opiniões sobre as ideias apresentadas, ao invés de realmente colaborar com ideias. Eles ajudaram na concepção da ideia, mas não fizeram parte integral dela" [Entrevistado 2]. Na sequência, esse entrevistado discorre sobre a propriedade intelectual: "todos os funcionários assinam um acordo de confidencialidade, que toda a produção é de propriedade da empresa DuPont" [Entrevistado 2]. Ele pondera que, em relação à inovação aberta, a empresa "deve estar aberta para seguir para onde o mundo está caminhando. Não podemos ficar parados. O processo é muito bom, mas não podemos nos prender. Temos que evoluir. Então, tem de parar e pensar como vamos evoluir, fazer isso de uma maneira mais segura [de forma a proteger a propriedade intelectual]" [Entrevistado 2]. Outro entrevistado também aponta a participação de clientes e consultores na etapa de apresentações: "às vezes, tínhamos a presença de universidades, mas era pouco frequente. Normalmente eram mais consultores" [Entrevistado 3]. Esse entrevistado comenta que, em relação à participação de clientes no processo de brainstorming, ele identifica duas preocupações: a primeira é a perda da propriedade intelectual, e a segunda é a perda de parte do valor do produto. Quando o cliente 
participa da formulação da ideia, ele pode questionar o valor da inovação, uma vez que ele contribui com o processo: "Tem se que ter um balanço para ver quando o cliente deve participar e quando não deve" [Entrevistado 3]. O entrevistado 5 confirma a preocupação com a perda da propriedade intelectual quando a ideia é gerada junto com o cliente, e sugere que deve haver um acordo prévio ao engajamento do cliente para definir qual o valor da contribuição de cada uma das partes, uma vez que vai se discutir tecnologia, se desenvolver algo, isso vai ser compartilhado. "[Deve-se definir formalmente] qual é a contribuição de cada parte" [Entrevistado 5]. O mesmo entrevistado apresenta a sua perspectiva quanto ao engajamento de universidades. Ele menciona que globalmente a empresa DuPont "tem presença importante em termos de colaboração externa, que inclui universidades e alguns institutos de pesquisa" [Entrevistado 5]. E acrescenta que a empresa DuPont tem alocado uma parcela de seu investimento em P\&D para essas parcerias. No Brasil, no entanto, segundo ele há dificuldade de engajar universidades nesses processos de inovação por questões de propriedade intelectual. De acordo com esse entrevistado, o conflito existe entre a confidencialidade que a empresa requer e a necessidade de um pesquisador de publicar as suas descobertas: "a empresa precisa de confidencialidade e o pesquisador, o melhor no seu campo, precisa publicar [as suas pesquisas] para crescer [na sua carreira]" [Entrevistado 5]. Ele também discorre sobre a questão de patentes, e indica que o Brasil segue normas internacionais, mas a propriedade intelectual é uma combinação de patente e know-how e a maior preocupação é a transferência de know-how quando se engajam as universidades, e por isso a necessidade de assinar um contrato de confidencialidade. Quanto à questão de patentes, ele argumenta que uma empresa "só consegue extrair valor [da inovação] no dia que ela estiver protegida. Se ela não está protegida, [a empresa] não vai querer comercializá-la" [Entrevistado 5]. O ambiente regulatório de um país tem que proteger o investimento em inovação.

Quando o projeto chega ao estágio de escalar para comercialização, o ambiente regulatório tem que proteger essa inovação. Enquanto a inovação está em fase de projeto, ela está dentro da empresa, existe o controle. Mas quando a inovação é lançada ao mercado, o ambiente regulatório tem que proteger o conhecimento desenvolvido [Entrevistado 5].

Esse entrevistado destaca que "umas empresas são mais inovadoras que outras porque têm processos mais sólidos, têm gente mais competente. Mas não adianta nada você ter uma ideia excelente se não tem um ambiente [regulatório do país que proteja a inovação]" [Entrevistado 5]. 
Quanto à participação das universidades, o entrevistado 8 compartilha o mesmo conflito mencionado pelo entrevistado 5, a confidencialidade das informações dentro de uma parceria de cooperação técnica.

Outro respondente confirma que nos ciclos em que participou os integrantes eram todos internos à organização e acredita que "[o processo] poderia ser mais frutífero se o cliente participasse" [Entrevistado 6]. Ele também cita o risco de perder a propriedade intelectual, "uma ideia tem um valor imenso, significa uma vantagem competitiva dentro da empresa. Talvez, se o cliente participasse, se perderia o ineditismo" [Entrevistado 6]. Mas ele acredita que "existem outros mecanismos para proteger uma ideia" e defende que "se o cliente participasse, seria [um processo] muito mais rico" [Entrevistado 6].

Um entrevistado acredita que o processo de brainstorming foi e deve continuar fechado, "durante o processo [de geração e definição da ideia] muita informação confidencial é compartilhada. Por mais que você coloque regras, as pessoas discutem [tecnologias e competências] que são confidenciais" [Entrevistado 7]. Ele sugere que as unidades de negócio façam um trabalho prévio de coleta de informação com as universidades, que estabeleçam esse relacionamento previamente e que os funcionários responsáveis pelo relacionamento levem as ideias no momento do brainstorming.

O entrevistado 8 comenta que presenciou a abertura para geração de ideias com clientes nos processos do Centro de Inovação, e acredita que a empresa DuPont poderia alavancar mais esse tipo de interação com os clientes, mas ele não cita o envolvimento de clientes no processo EMGI. Outro entrevistado relata a presença de cliente e de consultores apenas na etapa de brainstorming, enquanto se geravam ideias, ou seja, enquanto o grupo estava em um processo de divergência e não se discutiam soluções tecnológicas:

El cliente participaba y también muchas veces los consultores participaban en la parte de divergencia y en el primero paso de convergencia. Pero cuando ya estábamos llegando en los clusters, ya en desarrollar la idea, ahí ya había mucha información, pues mucha información confidencial. Entonces ahí limitábamos esa participación, en la mayoría de los casos, aun cuando en algunos casos dejábamos que el cliente o el consultor estuvieran en todo el proceso, pero ahí el agreement era un poquito diferente. El cliente y el consultor aceptaban que todas las ideas que salieran de ahí, aun cuando fuera de ellos algunas, serían propiedad de la empresa DuPont. Dependía mucho del 
tema, dependía mucho de que cliente, dependía mucho de qué tipo de negocio ${ }^{37}$ [Entrevistado 9].

Um entrevistado relata que a participação de clientes "podría haber ayudado bastante. Tal vez el proceso debió haber sido en dos partes, o sea, primeiro generación de idea y después el filtro. Entonces ahora invitamos a un cliente para confirmar nuestra idea" ${ }^{38}$ [Entrevistado 10]. Outro entrevistado cita a inovação aberta como um grande dilema: "si está abriendo, a lo mejor está mandando una idea afuera" 39 [Entrevistado 11]. Apesar da geração de ideias ser fechada, esse entrevistado destacou o esforço de trazer uma perspectiva $360^{\circ}$ do tema selecionado antes de se iniciar a sessão de brainstorming: "yo encontré cuando menos que en esos tres [procesos que participé] hicieron un esfuerzo para traer una perspectiva $360^{\circ}$. No sé si era mejor, pero creo que tenían la intención de hacerlo. Entonces donde trajeron gente de la academia, trajeron consultores, trajeron personas que sí tenían experiencia en materia de lo que hablábamos. Y intentando a lo mejor ampliar la visión"40 [Entrevistado 11]. Ele confirma a participação eventual de um consultor contratado no brainstorming.

Quanto à proposição de que a repetição dos participantes no processo afeta a geração de ideias inovadoras, constata-se que, nesse caso, identificou-se que a repetição afetou o desempenho do processo, levando à sensação de esgotamento de ideias inovadoras. Essa constatação está alinhada com os estudos de Poetz e Schreier (2012), que esclarecem que, após um certo ponto, a exploração do conhecimento interno reduz e acarreta um arrefecimento na geração de ideias. No entanto, o fator denominado de fixação cognitiva, apontado por Bayus (2013), bem como a limitação de ideias pela repetição dos participantes e a dependência com a sua história, aspectos apontados por Girotra, Terwiesch e Ulrich (2010), não foram identificados nesse processo.

\footnotetext{
37 Tradução livre da autora: "o cliente participava e também muitas vezes consultores partipavam na etapa de divergência, e no primeiro passo da convergência. Quando estávamos chegando na formação dos clusters e na hora de desenvolver a ideia já havia muita informação confidencial. Nessa hora, limitávamos a participação deles. Em alguns casos, queríamos que eles participassem de todo o processo, o acordo era diferente. $\mathrm{O}$ cliente ou o consultor aceitava que todas as ideias que saíssem do processo, inclusive as geradas por ele, seriam de propriedade da empresa DuPont. Dependia muito do tema, do cliente e do tipo de negócio."

${ }^{38}$ Tradução livre da autora: "[...] poderia ter ajudado bastante. Talvez o processo deveria ter sido em partes. Ou seja, a geração de ideias e depois o filtro. Então aí convidaríamos o cliente para confirmar nossa ideia."

39 Tradução livre da autora: "se está abrindo, ao menos está jogando uma ideia para fora."

${ }^{40}$ Tradução livre da autora: "eu encontrei que, ao menos nesses três [processos que participei], fizeram um esforço de trazer uma perspectiva $360^{\circ}$. Não sei se era o melhor, mas tinha a intenção que fosse. Trouxeram pessoas de universidades, consultores, pessoas com experiência no assunto. De forma a ampliar a visão."
} 
Já a proposição de a participação de somente funcionários no processo de geração de ideias ter limitado o conhecimento do grupo na geração de inovações pode ser considerada inconclusiva. Estudos adicionais são necessários para esclarecer se a participação direta de agentes externos possibilitaria aumentar o conhecimento do grupo e propiciar ideias de qualidade maior se estes participassem do processo como um todo. Destaca-se que a proposição de que os agentes externos não participavam é equivocada. Eles participavam, mas de uma forma controlada, e a participação em todas as etapas era, portanto, limitada.

Sugere-se que é necessária uma investigação adicional em relação ao processo de abrir o processo de geração de ideias e a proteção da propriedade intelectual, porque é considerado de extrema importância o engajamento de clientes para compartilhar as necessidades e fomentar ideias. A participação direta do cliente na fase de brainstorming do processo EMGI foi aplicada com cautela. Não se tratava de um processo que buscava atender pequenas necessidades, mas de um processo que buscava ideias inovadoras para mais de uma unidade de negócios. Dessa forma, buscaram-se formas alternativas de engajamento para trazer as necessidades de clientes para o processo. O maior engajamento de colaboradores externos pode ser uma alternativa para reduzir a sensação de esgotamento de ideias, entretanto é necessário adotar as melhores práticas para que a propriedade intelectual seja protegida ao longo do processo.

\subsection{PLANO DE NEGÓCIO DE ALTO NÍVEL E PLANO DE DESENVOLVIMENTO ESTRATÉGICO}

As fases seguintes ao processo de geração e pré-seleção de ideias foram comentadas por alguns entrevistados. Um deles destaca que "Aliás, essa era uma das áreas em que mais me surpreendia o nível de detalhes que se trazia para a sessão [de plano de negócio de alto nível]. Em alguns casos era impressionante o que se conseguia em um espaço de tempo muito curto" [Entrevistado $1]$.

$\mathrm{Na}$ fase do plano de negócio de alto nível era necessário que se verificassem dados de mercado e de clientes, e se engajavam clientes e especialistas no mercado para validar a proposta da ideia original: "Honestamente em alguns casos me impressionava positivamente com o nível de detalhes que traziam do tamanho do mercado, potencial de crescimento etc." [Entrevista 1]. 
Nessas fases era muito importante ter uma unidade de negócio liderando o processo, uma patrocinadora bem definida entre as múltiplas unidades envolvidas no projeto. Outro fator importante era ter um líder de projeto forte [Entrevistado 2]. Outro entrevistado destaca o papel do líder para a execução das fases seguintes: "O líder era um apaixonado pela ideia, tinha envolvimento emocional com ela" [Entrevistado 6].

$\mathrm{Na}$ fase de plano estratégico de alto nível o objetivo era definir os recursos necessários, gerar a estratégia do projeto e dar um rumo ao projeto que se queria implementar. Ideias foram paradas, principalmente ao completar essa fase, pois a análise econômica não era favorável ao projeto. Um entrevistado esclarece que a razão principal de se escolherem de dez a doze ideias por ciclo era a expectativa de que, ao longos dos gates, algumas ideias seriam abandonadas [Entrevistado 2]. Outro entrevistado [3] também cita que o processo realmente parava se os projetos durante essa fase não tivessem um business case.

Um entrevistado comenta que a verba era limitada e, portanto, a empresa só poderia apoiar alguns projetos. Por isso, a fase do plano de alto nível servia para ir a fundo e validar se o projeto tinha os requisitos para seguir em frente. Ele esclarece que "saía-se de um processo [de geração de ideias] onde se tinha algumas ideias [selecionadas], a partir de estimativas, mas a seleção ali era mais por feeling, porque os números eram muito prematuros" [Entrevistado 3].

Destaca também que, "uma vez que a ideia passava para as outras fases, existia um comprometimento em alocar recursos, em se fazer o estudo de sua viabilidade" [Entrevistado 3]. Em contrapartida, um entrevistado aponta que, como as pessoas não eram dedicadas ao projeto durante essas fases, havia conflito de prioridades. "Você tinha de fazer todas as suas atribuições e participar das reuniões de projeto, estudar e voltar. Teoricamente, teríamos de sair já fazendo pesquisa de mercado na hora... Para ter, em três meses, o resultado para apresentar, mas ocorriam atrasos" [Entrevistado 6]. A mesma questão de dedicação parcial dos recursos foi apontada por outro entrevistado [11].

Um respondente recorda que ao final do plano de alto nível acontecia a apresentação dos resultados. Ele presenciou um evento no qual catorze projetos foram apresentados e nem todos os participantes estavam presentes localmente. "Foi um processo cansativo" [Entrevistado 10]. O mesmo entrevistado comenta que ao final das apresentações os líderes votavam as 
características do projeto, conforme critério pré-estabelecido. No início o processo era manual e posteriormente mudou para uma aplicação, o que tornou o processo mais eficiente.

Outro entrevistado [8] demonstrou frustração pelo fato de a ideia com que contribuiu ter tido um problema e, por isso, não teve apoio para continuar como projeto. Ela foi aprovada na fase de pré-seleção, mas não se demonstrou economicamente viável e foi cancelada no gate do plano de alto nível.

Finalmente, um entrevistado destaca que o processo era bom, mas enfrentava a burocracia da empresa para aprovação dos projetos em outras esferas da organização. Enquanto a América Latina estava disposta a seguir com o projeto, no nível global da unidade de negócio e no nível de engajamento de outros pesquisadores e tecnologias, era necessário passar por processos de aprovação adicionais. 


\section{CONSIDERAÇÕES FINAIS, LIMITAÇÕES DA PESQUISA E PRINCIPAIS CONTRIBUIÇÕES}

As empresas estão sob constante pressão para se desenvolverem e se transformarem em líderes no(s) segmento(s) de atuação, de forma a criar ou manter uma vantagem competitiva. Essa transformação é impulsionada pela inovação, que desponta como uma prioridade nas empresas, segundo pesquisa da Boston Consulting Group (BCG, 2015). Cabe destacar que a inovação também é a força motriz para o avanço econômico de países desenvolvidos e em desenvolvimento (OECD, 2015a).

A inovação não ocorre ao acaso. Ela é o resultado de um processo claramente estabelecido para identificar necessidades, problemas ou oportunidades que possam ser solucionados por meio da inovação de produtos, processos e/ou métodos organizacionais ou de marketing (OECD, 2005).

Toda a inovação se origina de uma ideia que resolva as necessidades ou oportunidades identificadas. Para a ideia se tornar uma inovação, ela deve ser desenvolvida em um produto que agregue valor ao cliente final (KNIGHT, 1967; AMABILE, 1988; VAN DE VEN, 1986; GURTEEN, 1998; BJORK; MAGNUSSON, 2009).

Dentro do processo de inovação a ideia é, portanto, o ponto de partida, sendo o objetivo principal no processo de auxiliar na escolha da melhor ideia a ser transformada em produto e/ou serviço (TERWIESCH; ULRICH, 2009; GIROTRA; TERWIESCH; ULRICH, 2010). Decorrente disso, elegeu-se como objetivo principal deste estudo verificar como isso tem sido gerado na empresa DuPont, multinacional norte-americana de manufatura, reconhecida mundialmente pelas inovações, com atuação em mais de 90 países, e instalada no Brasil desde 1937.

Empresas bem-sucedidas em gerar inovação como a DuPont se baseiam em processos de inovação estruturados e disciplinados (DRUCKER, 2002) que permitam avaliar, a cada etapa, o progresso e a viabilidade do projeto. Dentre os processos definidos, destaca-se o Stage-Gate ${ }^{\circledR}$ 
definido por Cooper $(2001,2008)$. Durante esse processo, na primeira fase ocorre a geração, a seleção e o desenvolvimento de uma ideia em uma proposta de projeto para o desenvolvimento de um produto e essa fase é denominada mais comummente como pré-desenvolvimento ou Front End of Innovation (FEI).

Estudos empíricos demonstram que o FEI é uma fase crítica para o processo de inovação. As ideias selecionadas durante essa fase são críticas para o sucesso do processo de inovação (HERSTATT; VERWORN, 2001; KOEN et al., 2001; COOPER; EDGETT; KLEINSCHMIDT, 2002; REID; BREITANI, 2004). Dentro do FEI, a geração de ideias ocorre quando os participantes são capazes de unir o seu conhecimento com a criatividade (AMABILE, 1988). Dentro desse processo, a criatividade é estimulada pelo ambiente organizacional criativo e a liderança deve desenvoler competências para gerir a criatividade e a aplicação de métodos, ferramentas e/ou técnicas que estimulem o pensamento criativo no grupo (BREM; PUENTE-DIAZ; AGOGUÉ, 2016).

Na geração de ideias, o método aplicado, juntamente com a diversidade dos participantes, busca aumentar a qualidade das ideias geradas. Dentro do processo de inovação, as empresas estão em busca de ideias de qualidade, que possuam maior potencial de estabelecer uma vantagem competitiva (BJORK; MAGNUSSON, 2009; GIROTRA; TERWIESCH; ULRICH, 2010; HIRUNYAWIPADA; PASWAN; BLANKSON, 2015).

O método mais utilizado para a geração de ideias é o brainstorming, disseminado por Osborn (1957, apud DIEHL; STROEBE, 1987), que pode ter os seus resultados negativamente afetados por acomodação, apreensão ou bloqueio de produção por parte dos participantes (DIEHL; STROEBE, 1987). O método também pode ser afetado pela conformidade dos participantes com outros membros do grupo (JANIS, 1982, apud GIROTRA; TERWIESCH; ULRICH, 2010). Uma alternativa identificada para superar esses fatores negativos foi identificado por Paulus e Yang (2000), como sendo uma variação do brainstorming, denominado brainwriting. Os participantes também podem ser afetados pela fixação cognitiva (BAYUS, 2013) e a repetição de participantes pode limitar a geração de ideias inovadoras, pela possível dependência criada entre a ideia gerada pelo grupo e a sua história (GIROTRA; TERWISCH; ULRICH, 2010) 
É natural que muitas organizações busquem as ideias internamente (HANSEN; BIRKINSHAW, 2007), tendo como participantes de seus processos de geração de ideias somente funcionários. Chesbrough (2003), no entanto, aponta a adoção da inovação aberta como uma opção para as empresas usufruírem de um volume imensurável de conhecimento disponível em recursos externos à organização. Chesbrough (2004) sugere o engajamento de clientes e comunidades de clientes no processo de inovação. Da mesma forma, Prahalad e Ramaswamy (2004) sugerem a cocriação entre consumidores e times internos. Von Hippel (2005) e Lilien e colaboradores (2002) indicam a inclusão de lead-users no processo de geração de ideias. Boudreau e Lakani (2013) recomendam um alcance mais abrangente: utilizar crowds para a geração de ideias.

Esta pesquisa foi desenvolvida para entender os fatores que afetam a geração de ideias em relação ao método aplicado e aos participantes envolvidos e teve por objetivo analisar como o processo de geração de ideias para desenvolvimento de novos produtos está sendo desenvolvido na empresa DuPont, visando apresentar soluções e melhorias nos fatores estudados. Os objetivos específicos estavam direcionados a estudar a geração de ideias, identificar alternativas para melhorar a qualidade das ideias geradas com os participantes engajados no processo e identificar sugestões para melhorar o método aplicado para geração de ideias.

Para atender ao principal objetivo selecionou-se como método de pesquisa o estudo de caso único, com finalidade exploratória. $\mathrm{O}$ caso selecionado trata de um processo de inovação específico, denominado Emerging Markets Growth Initiative (EMGI), implementado pela liderança da região América Latina da empresa DuPont. O processo EMGI tem por objetivo identificar soluções para necessidades específicas dos mercados dos países emegentes da América Latina, por meio da colaboração de pelo menos duas unidades de negócios para desenvolver novos produtos que agreguem valor. Porter e Kramer (2011) destacam que há necessidades específicas em países emergentes, e que as empresas globais precisam se atentar para a importância da inovação em produtos ou processos para esses mercados, criando soluções específicas ou redesenhando soluções existentes. O processo EMGI busca atender um nicho específico de necessidades que não têm como serem atendidas por um único negócio e que não teriam prioridade em outros processos de inovação globalizados.

A coleta de dados foi realizada utilizando entrevistas em profundidade, de forma semiestruturada com uma amostra intencional não probabilística de onze participantes do 
processo EMGI. Para a análise dos dados coletados as respostas das entrevistas foram agrupadas em categorias e as menções de cada entrevistado foram analisadas, de forma comparativa, com o embasamento teórico.

A análise de dados buscou responder às três proposições iniciais deste estudo: 1) A técnica utilizada para gerar ideias limita a geração de ideias inovadoras em situações que requerem conhecimento de múltiplos negócios; 2) A repetição dos participantes na geração de ideias afeta a geração de ideias inovadoras; 3) A participação restrita a funcionários limita o conhecimento do grupo na geração de ideias.

Com base nos resultados, constata-se que a empresa selecionada possui diversos processos de inovação, cada um com um objetivo específico, e conclui-se que uma empresa inovadora pode adotar múltiplos processos de inovação para atender às oportunidades e manter suas fontes de inovação. Na empresa DuPont, no que diz respeito à América Latina, todas estas são intencionalmente estabelecidas, estruturadas e disciplinadas como recomendam alguns teóricos (UTTERBACK, 1970; COOPER, 1988; DRUCKER, 2002; COOPER, 2001, 2008). O processo EMGI está estruturado em todas as suas fases, incluindo as sequências de etapas e gates, para que os patrocinadores acompanhem o processo e avaliem a viabilidade do projeto antes de seguir para o próximo estágio, conforme sugere Cooper (2001, 2008).

O processo EMGI empregou diversas técnicas e métodos (COOPER, 1988; KOEN et al., 2002) para a etapa de geração de ideias no intuito de identificar a mais propícia para o processo. Avaliando as técnicas de brainstorming utilizadas ao longo dos anos na empresa, conclui-se que a técnica de brainwriting também tem sido utilizada (PAULUS; YANG, 2000), pois os participantes geravam ideias sozinhos (escrevendo as ideias em post-its) (PAULUS; YANG, 2000). De posse das ideias, o grupo trabalhava em conjunto para melhorá-las (PAULUS; BROWN, 2007). As discussões entre os membros do grupo para rever, agrupar, aprimorar, compor e agregar as ideias apresentadas permitia a discussão entre diferentes membros do grupo, o que incentivava o processo criativo (GURTEEN, 1998). Em relação à proposição 1, conclui-se, assim, que a técnica de brainstorming utilizada não limitou a geração de ideias inovadoras em situações que requerem conhecimento de múltiplas áreas de negócios e que não há melhorias a serem sugeridas. 
O processo EMGI focou intencionalmente na diversidade dos participantes entre diferentes unidades de negócios e funções, o que está alinhado com autores que indicam que a melhoria na qualidade da ideia ocorre quando as organizações adotam a colaboração entre unidades de negócios (HANSEN; BIRKINSHAW, 2007) e times multifuncionais (KOEN et al., 2002). No que tange à diversidade, também foi estabelecido que, dentre os participantes, deveria existir diversidade de opiniões, gênero, cultura e conhecimento, entre outros fatores. Além disso, dentre os participantes, a liderança da América Latina estava presente em todas as etapas para selecionar e investir nas ideias inovadoras (BACON et al., 1994; KHURANA; ROSENTHAL, 1998; KIM; WILEMON, 2002; GASSMANN; SCHWEITZER, 2014; KOEN; BERTELS; KLEINSCHMIDT, 2014a).

Apesar da busca de diversidade, constatou-se a repetição de alguns participantes ao longo dos ciclos, o que foi considerado um dos fatores para a diminuição do volume de ideias inovadoras. Em relação à proposição 2 conclui-se que, nesse caso, essa repetição afetou o desempenho do processo, levando à sensação de esgotamento de ideias inovadoras. Essa constatação está alinhada com os estudos de Poetz e Schreier (2012), que esclarecem que, após um certo ponto, a exploração do conhecimento interno reduz e acarreta um arrefecimento na geração de ideias.

A inovação aberta era aplicada com cautela dentro do processo EMGI. O envolvimento de clientes e de suas necessidades para o processo de geração de ideias era considerado imprescindível para que as soluções propostas atendessem às suas necessidades (GOLDERNBERG; LEHMANN; MAZURSKY, 2001; KIM; WILEMON, 2002). Entretanto, o balanço entre abrir o processo e proteger a propriedade intelectual foi um fator necessário e também tem sido considerado (GASSMANN; ENKEL; CHESBROUGH, 2010). Assim, a cada ciclo era definido, caso a caso, como o engajamento de clientes e outros agentes externos seria feito (GASSMANN; SANDMEIER; WELCHT, 2006). O processo EMGI permitiu a circulação de ideias externas à organização de diferentes formas para aumentar as chances de sucesso no processo de geração de ideias (CHESBROUGH, 2003; GASSMANN, 2006). Quanto à proposição 3, que suspeitava que a participação de somente funcionários no processo de geração de ideias limitava o conhecimento do grupo na geração de inovações, é considerada inconclusiva, pois há indicações de alguns respondentes que isso não ocorre. Destaca-se que a proposição, nas respostas de alguns entrevistados, de que os agentes externos não participavam é equivocada. Eles participavam como convidados, mas de forma controlada, pois isso não ocorria em todas as etapas do processo, ou seja, era apenas limitada. 
O maior engajamento de colaboradores externos pode ser uma alternativa para reduzir a sensação de esgotamento de ideias, entretanto, é necessário adotar as melhores práticas para que a propriedade intelectual seja protegida ao longo do processo. Sugere-se que é necessária uma investigação adicional em relação ao processo de abrir o processo de geração de ideias e a proteção da propriedade intelectual corrente e futura no Brasil em processos abertos de geração de ideias.

Para estudos futuros, sugere-se aprofundar o papel do facilitador como agente crítico para liderar o processo criativo. Conforme apontado por Brem, Puente-Diaz e Agogué (2016), existe a necessidade de estudos adicionais nesse campo para entender como o facilitador deve atuar para promover uma liderança criativa. Finalmente, propõe-se explorar como utilizar os diferentes estilos de aprendizados de Kolb e Kolb (2005), visando potencializar os resultados das diferentes etapas do processo de inovação.

Cabe ressaltar que esta dissertação tem como limitação o fato de se tratar de um estudo de caso único, com o objetivo específico de aprofundamento da fase de geração de ideias de um dos processos de inovação da empresa DuPont, e que as suas descobertas, portanto, não podem ser generalizadas. Além disso, foram entrevistados poucos participantes dentro do processo, que já teve cerca de cento e vinte pessoas envolvidas durante os doze anos de existência do processo EMGI, não sendo, do mesmo modo, representativa para a região da América Latina. 


\section{REFERÊNCIAS}

AMABILE, Teresa M. A model of creativity and innovation in organizations. Research in Organizational Behavior, v. 10, p. 123-167, 1988.

How to kill creativity? Harvard Business Review, set - out, 1998.

BACON, Glenn et al. Managing product definition in high-technology industries: a pilot study. California Management Review. p. 32-56, Spring, 1994.

BARDIN, Laurence. Análise de Conteudo. Edições 70, 1977.

BAYUS, Barry L. Crowdsourcing new product ideas over time: an analysis of the Dell idea storm community. Management science. Chapel Hill: University of North Carolina, n. 1, v. 59, p. 226-244, 2013.

BCG. BCG Perspectives: innovation in 2015, dez, 2015. Disponível em:

$<$ https://www.bcgperspectives.com/content/articles/growth-lean-manufacturing-innovationin-2015/>. Acesso em: 08 abr. 2015.

BESSANT, John; LAMMING, Richard; NOKE, Hannah; WENDY, Phillips. Managing innovation beyond the steady state. Technovation, n. 25, p. 1366-1376, 2005.

BJORK, Jennie; MAGNUSSON, Mats. Where do good innovation ideas come from? Exploring the influence of network connectivity on innovation idea quality. Journal Product Innovation Management, n. 26, p 662 - 670, 2009.

BOEDDRICH, Heinz-Juergen. Ideas in the workplace: a new approach towards organizing the fuzzy front end of the innovation process. Creativity \& Information Management, v. 13, n. 4, dez. 2004.

BOUCHARD, Thomas J.; HARE, Melana. Size, performance, and potential in brainstorming groups. Journal of Applied Psychology, v.54, n. 1 p. 51-55, 1970.

BOUDREAU, Kevin J.; LAKHANI, Karim R. Using the crowd as an innovation partner. Harvard Business Review, abr., 2013.

BREAKTHROUGH. Growth strategy, [2015]. Disponível em:

<http://breakthroughgroup.com/what-we-do/growth-strategy/>. Acesso em: 8 abr. 2015.

BREM, Alexander; PUENTE-DIAZ, Rogelio; AGOGUÉ, Marine. Creativity and innovation: state of the art and future perspectives for research. International Journal of Innovation Management, v. 20, n. 4, mai., 2016.

CHESBROUGH, Henry. Open innovation: the new imperative for creating and profiting from technology. Boston, MA: Harvard Business Press, 2003. 
. Managing open innovation. Research-technology management., Arlington, VA: Industrial Research Institute, n. 1, v. 47, p. 23-26, 2004.

CHRISTENSEN, Claytion M. The innovator's dilemma: when new technologies cause great firm's to fail. Harvard Business Review Press, Boston, Massachussets, 2000.

CHRISTENSEN, Clayton M.; RAYNOR, Michael; MCODNALD, Rory. O que é inovação disruptiva? Harvard Business Review, v. 93, n. 12, p.21-30, 2015.

CLARK, Kim; WHEELWRIGHT, Steven C. Managing new product and process development: Text and cases. The Free Press, New York, 2010. Kindle Edition.

COOPER, Robert G. Predevelopment activities determine new product success. Industrial Marketing Management, v. 17, p. 237-247, 1988.

Winning at New Products: accelerating the process from idea to launch. 3. ed. Reading, MA: Perseus Books, 2001.

Perspective: The stage-gate idea-to-launch process - update, what's new and nexgen systems. Journal Product Innovation Management, v.25, n. 3 p. 213-232, mai. 2008.

COOPER, Robert G.; EDGETT, Scott J.; KLEINSCHMIDT, Elko J. Optimizing the stagegate process: what best practice companies are doing (part one) Research Technology Management, v.45, n. 5, 2002.

COOPER, Robert G.; KLEINSCHMIDT, Elko J. An investigation into new product process. Journal of Product Innovation Management, n. 4, p. 71-85 1986.

Major new products: what distinguishes the winner in the chemical industry?

Journal Product Innovation Management, v.10, p. 90-111, 1993.

DIEHL, Michael; STROEBE, Wolfgang. Productivity loss in brainstorming groups: toward the solution of a riddle. Journal of Personality and Social Psychology, v. 53, n. 3, p. 497$509,1987$.

DRUCKER, Peter F. The discipline of innovation. Harvard Business Review, ago. 2002. Disponível em: <https://hbr.org/2002/08/the-discipline-of-innovation>. Acesso em: 08 abr 2016.

DUPONT. DuPont Armura sistema de blindagem. [2008]. Disponível em:

<http://www.dupont.com.br/dpt/armura/dupont-armura.html>. Acesso em: 07 abr. 2015.

2015 DuPont data book, mar, 2016a. Disponível em:

<http://s2.q4cdn.com/752917794/files/doc_downloads/2015/DuPont_2015_DataBookFINAL.pdf>. Acesso em: 09 jun 2016.

DuPont Innovation Centers. [2016b].Disponível em:

<http://www.dupont.com/corporate-functions/our-approach/innovationexcellence/science/innovation-centers.html>. Acesso em: 09 jun. 2016. 
DuPont scientists and engineers. [2016c]. Disponível em:

$<$ http://www.dupont.com/corporate-functions/our-approach/innovationexcellence/science/scientists-engineers.html>. Acesso em: 09 jun. 2016.

Innovation Starts Here. [2016d]. Disponível em:

$<$ http://www.dupont.com/corporate-functions/our-company/dupont-history.html $>$. Acesso em: 09 jun. 2016.

Our company. [2016e]. Disponível em: <http://www.dupont.com/corporate-

functions/our-company.html>. Acesso em: 09 jun. 2016.

Science and Technology at DuPont. [2016f]. Disponível em:

$<$ http://www.dupont.com/corporate-functions/our-approach/innovationexcellence/science/science-and-technology.html>. Acesso em: 09 jun. 2016.

ETTLIE, John E.; BRIDGES, William P.; O'KEEFE, Robert D. Organizational strategy and structural differences for radical versus incremental innovation. Management Science, v. 30, n. 6, p. 682-695, 1984.

FELIX, Antônio; GALEMBECK, Flávia; CUNHA, Lílian. Best Innovator: conheça as empresas mais inovadoras de 2015. Época Negócios, 11 nov. 2015. Disponível em: $<$ http://epocanegocios.globo.com/Empresa/noticia/2015/11/best-innovator-conheca-empresasmais-inovadoras-de-2015.html>. Acesso em: 01 jun. 2016.

FERRO, Ana F. P. Gestão da inovação aberta: práticas e competências em P\&D Colaborativa. Campinas, 2010. Tese (Doutorado em Política Científica e Tecnológica) Programa de Pós-Graduação em Política Científica e Tecnológica, Instituto de Geociências, Universidade Estadual de Campinas.

FLETCHER, Antony. IFT: Solae unveils new protein technology. FOOD navigator.com, 28 jun. 2006. Disponível em: <http://www.foodnavigator.com/Market-Trends/IFT-Solaeunveils-new-protein-technology>. Acesso em: 18 out. 2014.

G1. Protesto de taxistas contra o Uber congestiona as principais vias do RJ. Globo.com, 01 abr. 2016. Disponível em: <http://g1.globo.com/bom-dia-brasil/noticia/2016/04/protesto-detaxistas-contra-o-uber-para-principais-vias-do-rj.html>. Acesso em: 05 Apr. 2016.

GASSMANN, Oliver. Opening up the innovation process: towards an agenda. R\&D management, v. 36, n. 3, p. 223-228, 2006.

GASSMANN, Oliver; ENKEL, Ellen; CHESBROUGH, Henry. The future of open innovation. R\&D management, v. 40, n. 3, p. 213-221, 2010.

GASSMANN, Oliver; SANDMEIER, Patricia; WECHT, Christoph H. Extreme customer innovation in the front-end: learning form a new software paradigm. International Journal of Technology Management, v. 33, n. 1, p. 46-66, 2006.

GASSMANN, Oliver; SCHWEITZER, Fiona. Managing the unmanageable: The Fuzzy Front End of innovation. In: GASSMANN, Oliver; SCHWEITZER; Fiona. Management of the Fuzzy Front End of Innovation. Suíça: Springer International Publishing, 2014. 
GAUBINGER, Kurt; RABI, Michael. Structuring the front end of innovation. In GASSMANN, Oliver; SCHWEITZER, Fiona. Management of the Fuzzy Front End of Innovation. Suíça: Springer International Publishing, 2014.

GIL, Antônio C. Métodos e técnicas de pesquisa social. São Paulo: Atlas, 2010.

GIROTRA, Karan; TERWIESCH, Christian; ULRICH, Karl T. Idea generation and the quality of the best idea. Management Science, n. 4, v. 56, p. 591-605, 2010.

GOLDENGERG, Jacob; LEHMANN, Donald R.; MAZURSKY, David. The idea itself and the circumstances of its emergence as predictors of new product success. Management Science, n. 1, v. 47, p. 69-84, 2001.

GURTEEN, David. Knowledge, creativity and innovation. Journal of Knowledge Management, v.2, n. 1, p. 5-13, 1998.

HAIR, Joseph F.; BABIN, Barry; MONEY, Arthur H.; SAMOUEL, Phillip. Fundamentos de métodos de pesquisa em administração. Porto Alegre: Bookman, 2005.

HANSEN, Morten T.; BIRKINSHAW, Julian. The innovation value chain. Harvard Business Review, p. 1-12, jun. 2007.

HENDERSON, Rebecca M.; CLARK, Kim B. Architectural innovation: the reconfiguration of existing product technologies and the failure of established firms. Administrative Science Quarterly, n. 35, p. 9-30, 1990.

HERSTATT, Cornelius; VERWORN, Birgit. The "fuzzy front end" of innovation. Technologie-und Innovationsmanagement, Technishe Universitat Hamburg-Harburg, n. 4, (working paper), 2001.

HSIEH, Hsiu-Fang; SHANNON, Sarah E. Three approaches to qualitative content analysis. Qualitative Health Research. Salt Lake City, UT: Sage Publications, v. 15, n. 9, p. 12771288, 2005.

HUMPHREY, Albert. SWOT analysis for management consulting. SRI Alumni association newsletter. Menlo Park, CA: SRI international, n. 1, p. 1-16, 2005.

HYRUNYAWIPADA, Tanawat; PASWAN, Audhesh K.; BLANSON, Charles. Toward the development of new product ideas: asymmetric effects of team cohesion on new product ideation, Journal of Business \& Industrial Marketing, v. 30, n. 7, p. 855-866, 2015.

IBM. The customer-centric enterprise: Insights from the global C-suite study. IBM Global Business Services, 2013.

KAVADIAS, Stylianos; SOMMER, Svenja C. The effects of problem structure and team diversity on brainstorming effectiveness. Management Science, n. 12, v. 55, p. 1899-1913, 2009.

KHURANA Anil; ROSENTHAL, Stephen R. Integrating the fuzzy front end of new product development. MIT Sloan Management Review, Winter. 1997. 
Towards holistic "front ends" in new products development. Journal of Product

Innovation Management, v. 15, n. 1, p. 57-74, jan. 1998.

KIM, Jongbar; WILEMON, David. Focusing the Fuzzy Front-End in new product development. R\&D management, v. 32, n. 4, p. 269-279, 2002.

KING, Andrew; LAKHANI, Karim R. Using open innovation to identify the best ideas. MIT Sloan Management Review, out. 2013.

KNIGHT, Kenneth E. A descriptive model of the intra-firm innovation process. Journal of business, v. 40, n. 4, p. 478-496, 1967.

KOLB, Alice Y.; KOLB, David A. The Kolb Learning Style Inventory-Version 3.12005

Technical Specifications. Boston, MA: Hay Group, Hay Resources Direct, 2005

KOEN, Peter A. et al. Providing clarify and common language to the Fuzzy Front End.

Research Technology Management, p. 46-55, mar.-abr. 2001.

KOEN, Peter A. et al. Fuzzy Front End: effective Methods, tools, and techniques. In:

BELLIVEAU, Paul; GRIFFIN, Abbie; SOMERMEYER, Stephen. The PDMA Toolbook for

New Product Development. New York: John Wiley \& Sons, Inc., p. 5-36, 2002. cap. 1.

KOEN, Peter. A.; BERTELS, Heidi M. J.; KLEINSCHIMIDT, Elko. Managing the front end of innovation - part I. Research Technology Management, p. 34-43, mar.-abr. 2014.

Managing the front end of innovation - part II. Research Technology Management, p. 25-35, mai.-jun. 2014.

KOZINETS, Robert V.; HEMETSBERGER, Andrea; SCHAU, Hope J. The wisdom of consumer crowds: collective innovation in the age of networked marketing. Journal of Macromarketing, v. 28, n.4, p. 339-354, dez. 2008.

LILIEN, Gary L. et al. Performance assessment of the lead user idea generation process for new product development. Management Science, v. 48, n. 8, p. 1042-1059, 2002.

MARTINS, Ellen C.; TERBLANCHE, Fransie. Building organisational culture that stimulates creativity and innovation. European journal of innovation management, v. 6, n. 1, p. 64-74, 2003.

MARTINS, Gilberto A.; THEÓPHILO, Carlos R. Metodologia da investigação científica para ciências sociais aplicadas. São Paulo: Atlas, 2007.

MCADAM, Rodney; MCCLELLAND, John. Individual and team-based idea generation.

European Journal of Innovation Management, v.5, n. 2, p. 86-97, 2002.

MIND TOOLS. The futures wheel: identifying future consequences.[2016] Disponível em: <http://www.mindtools.com/pages/article/futures-wheel.htm>. Acesso em: 09 abr. 2016.

MORAES, Roque. Análise de conteúdo. Revista Educação, Porto Alegre, v. 22, n. 37, p. 7$32,1999$. 
MULLEN, Brian; JONHSON, Craig; SALAS, Eduardo. Productivity loss in brainstorming groups: a meta-analytic integration. Basic and Applied Social Psychology, v.21, n.1, p. 3-23, 1991.

NORMAN Wayne; MACDONALD, Chris. Getting to the bottom of 'Triple Bottom Line,'. Business Ethics Quarterly, v.14, n. 2, p. 243-262, 2003.

OECD. Oslo Manual. Guidelines for collecting and interpreting innovation data, 3. ed. Paris: OECD Publishing, 2005.

OECD. The innovation imperative: contributing to productivity, growth, and well-being. OECD, 2015a. Disponível em: 〈http://dx.doi.org/10.1787/9789264239814-en>. Acesso em: 09 abr 2016.

OECD. Science, Technology and Industry Scoreboard 2015: Innovation for growth and society. OECD, 2015b, Disponível em: 〈http://www.keepeek.com/Digital-AssetManagement/oecd/science-and-technology/oecd-science-technology-and-industryscoreboard-2015/business-r-amp-d_sti_scoreboard-2015-27-en\#page1>. Acesso em: 09 abr. 2016.

O'REILLY III, Charles A.; TUSHMAN, Michael L. The ambidextrous organization. Harvard Business Review, abr. 2004.

PAULUS, Paul; BROWN, Vincent R. Toward more creative and innovative group idea generation: a cognitive-social motivational perspective of brainstorming. Social and Personality Psychology Compass, v. 1, p. 248-265, 2007.

PAULUS, Paul; YANG, Huei-Chuan. Idea generation in groups: a basis for creativity in organizations. Organizational Behavior and Human Decision Process, v. 82, n.1, p. 76-87, mai. 2000.

PINHO, Marcelo; FERNANDES, Ana C. Relevance of university-industry links for firms from developing countries: exploring different surveys. In: ALBUQUERQUE, Eduardo; SUZIGAN, Wilson; KRUSS, Glenda; LEE, Keun. Developing national systems of innovation. Edward Elgar Publishing, 2015.

POETZ, Marion K.; SCHREIER, Martin. The value of crowdsourcing: can users really compete with professionals in generating new product ideas? Journal of product innovation management, v. 29, n. 2, p. 245-256, 2012.

PORTER, Michael; KRAMER, Mark R. The big idea: creating shared value. Harvard business review, v. 89, n. 1, jan. 2011. Disponível em: <http://hbr.org/2011/01/the-big-ideacreating-shared-value/ar/pr>. Acesso em: 18 out. 2014.

PRAHALAD, C. K.; RAMASWAMY, Venkat. Co-creation experiences: the next practice in value creation. Journal of interactive marketing, v. 18, n. 3, p. 5-14, 2004.

REID, Susan E.; BRENTANI, Ulrike. The fuzzy front end of new product development for discontinuous innovations: a theoretical model. Journal of Product Innovation

Management, v. 21, p. 170-184, 2004. 
SÁ, Nelson. Serviços como Netflix começam a afetar TV no mundo, diz estudo. Folha de São Paulo, 20 Ago2015. Disponível em:

<http://www1.folha.uol.com.br/mercado/2016/02/1739187-servicos-como-netflix-comecama-afetar-tv-no-mundo-diz-estudo.shtml> . Acesso em: 05 abr. 2016.

SCHUMPETER, Joseph. Capitalismo, Socialismo e Democracia. Rio de Janeiro: Editora Fundo de Cultura, 1961.

SCHWAB, Klaus. The fourth industrial revolution: what it means and how to respond. Foreign Affairs, dez. 2015. Disponível em: <https://www.weforum.org/agenda/2016/01/thefourth-industrial-revolution-what-it-means-and-how-to-respond>. Acesso em: 05 abr 2016.

SPOTORNO, Karla. De olho nas metas. Época Negócios, 04 out. 2011. Disponível em: $<$ http://epocanegocios.globo.com/Revista/Common/0,EMI270460-16380,00DE+OLHO+NAS+METAS.html>. Acesso em: 18 out. 2014.

SUTTON, Robert I.; HARGADON, Andrew. Brainstorming groups in context; effectiveness in a product design firm. Administrative Science Quarterly, n. 41, p. 685-718, 1996.

TERWIESCH, Christian.; ULRICH, Karl T. Innovation tournaments: creating and selecting exceptional opportunities. Boston: Harvard Business School Press, 2009.

TERWIESCH, Christian; XU, YI. Innovation contests, open innovation, and multiagent problem solving. Management Science, v.54, n. 9, p. 1529-1543, set. 2008.

THE MILLENIUM PROJECT. Jeremy Glenn. 2012. Disponível em: < http://www.millennium-project.org/millennium/jglenn.html>. Acesso em: 09 abr. 2016.

UTTERBACK, James M. The process of innovation: a study of origination and development of ideas for new scientific instruments. Library Massachusetts Institute of Technology, 1970.

VAN DE VEN, Andrew V. Central problems in the management of innovation. Management Science, n. 5, v. 32, p. 590-607, 1986.

VON HIPPEL, Eric. Lead users: an important source of novel product concepts. Management Science, v. 32, n. 7, p. 791-805, jul. 1986.

Democratizing Innovation. The MIT Press, 2005.

WANICK, Eduardo W. Driving science-based innovation in Latin America. In: MIT Brazil Forum, abr. 2011.

YIN, Robert K. Estudo de Caso. Planejamento e métodos. 4. ed. Porto Alegre: Bookman, 2010. 


\section{APÊNDICE: INSTRUMENTO DE PESQUISA}

Data da Entrevista:

Nome do(a) entrevistado(a):

Cargo:

País:

Unidade de Negócio em que Trabalha:

Anos de Empresa:

O intuito desta pesquisa é o processo específico de geração de ideias, desta forma as perguntas seguintes focarão no processo e participantes do processo de geração de ideias:

\section{Bloco 1 - Sobre o Processo EMGI}

1. De quantos processos EMGI você já participou?

2. Como você avalia o sucesso do processo durante os anos que foi executado?

3. Qual a sua percepção sobre o processo EMGI?

EXPLORAR: Há pontos positivos? Quais? Há pontos negativos? Quais?

4. Como você descreve esse processo de geração de ideias?

EXPLORAR: Qual a opinião quanto à qualidade das ideias? E quanto ao volume de ideias geradas? E quanto à variedade/diversidade de ideias sobre o assunto?

5. Como você percebe o uso da técnica de brainstorming / futures wheel que tem sido utilizada no processo EMGI?

6. Quais situações positivas, específicas do processo, você acredita que influi nos resultados?

7. Quais situações negativas, específicas do processo, você acredita que influi nos resultados? 


\section{Bloco 2 - Sobre a Participação no Processo EMGI}

8. Como você descreve a participação das pessoas no grupo durante o processo?

9. Qual a sua percepção sobre a adaptação dos participantes [devido à influência] no grupo?

10. Qual sua opinião sobre o julgamento dos outros participantes nas ideias apresentadas?

\section{Bloco 3 - Sobre a Geração de Ideias}

11. Você teve alguma ideia que passou para as fases seguintes?

EXPLORAR: SE RESPONDEU “SIM” NA PERG. ANTERIOR: Quantas ideias você se recorda de ter contribuído para o processo?

12. Poderia me descrever como tem sido a fase de geração de ideias?

EXPLORAR: Como avalia as ideias em termos de inovação? Conte algumas que considera inovadoras. E em termos de repetição de ideias? Há ideias similares a anteriores? Poderia me descrever as que considera repetidas?

13. Você acredita que o processo estimula a criatividade para o processo de geração de ideias?

14. Você acredita que os participantes têm conhecimento dos assuntos discutidos para participar dos grupos?

15. Qual sua percepção quanto a encontrar ideias que sejam multi-business?

16. Qual sua percepção quanto ao desafio não ser baseado em uma necessidade real?

17. Como você avalia os participantes geralmente selecionados para participação das sessões de brainstorming/futures wheel?

18. Como você avalia a repetição dos participantes?

19. Como você avalia o fato de o processo incluir somente pessoas internas da organização?

20. Como você avalia a possibilidade de ter o envolvimento de clientes/ consumidores ou 
parceiros no processo de geração de ideias?

21. Como você avalia a possibilidade de ter o envolvimento de universidades participando diretamente no processo de geração de ideias?

22. Você acredita que se o processo de geração de ideias tivesse participação direta de clientes, universidades, consumidores os resultados seriam diferentes do que está sendo feito nos últimos anos? Por quê?

\section{Bloco 4 - Sobre a investigação inicial: mercado, técnica e preliminar}

23. Você já participou da segunda etapa: avaliação de mercado, técnica e preliminar? EXPLORAR: SE RESPONDEU "SIM, JÁ PARTICIPOU": Você se recorda de ter contribuído para o processo?

[CASO NÃO TENHA PARTICIPADO DESSA ETAPA DEVE RESPONDER ÀS QUESTÕES A PARTIR DE SUA PERCEPÇÃO SOBRE O PROCESSO.]

24. Poderia me descrever como tem sido essa fase de avaliação de mercado, técnica e preliminar?

25. Você acredita que o processo estimula a criatividade para a avaliação de mercado, técnica e preliminar?

26. Você acredita que os participantes têm conhecimento dos assuntos discutidos para participar dessa etapa?

\section{Bloco 5 - Sobre a definição de conceito: identificação do conceito, desenvolvimento, teste, avaliação}

27. Você já participou da última etapa: identificação do conceito, desenvolvimento, teste, avaliação?

EXPLORAR: SE RESPONDEU “SIM, JÁ PARTICIPOU”: Você se recorda de ter contribuído para o processo?

[CASO NÃO TENHA PARTICIPADO DESSA ETAPA DEVE RESPONDER ÀS QUESTÕES A PARTIR DE SUA PERCEPÇÃO SOBRE O PROCESSO.] 
28. Poderia me descrever como tem sido essa fase de identificação do conceito, desenvolvimento, teste, avaliação?

29. Você acredita que o processo estimula a criatividade para a fase de identificação do conceito, desenvolvimento, teste, avaliação?

30. Você acredita que os participantes têm conhecimento dos assuntos discutidos para participar dessa etapa? 